UNIVERSIDADE FEDERAL DE JUIZ DE FORA

PROGRAMA DE PÓS-GRADUAÇÃO EM BIODIVERSIDADE E CONSERVAÇÃO DA NATUREZA

PEDRO HENRIQUE MONTEIRO DO AMARAL

NASCENTES TROPICAIS EM ÁREAS DE SILVICULTURA DO EUCALIPTO: ESTRUTURA E COMPOSIÇÃO DE EPHEMEROPTERA, PLECOPTERA E TRICHOPTERA (INSECTA)

Juiz de Fora 
PEDRO HENRIQUE MONTEIRO DO AMARAL

\title{
NASCENTES TROPICAIS EM ÁREAS DE SILVICULTURA DO EUCALIPTO: ESTRUTURA E COMPOSIÇÃO DE EPHEMEROPTERA, PLECOPTERA E TRICHOPTERA (INSECTA)
}

\begin{abstract}
Tese apresentada ao Programa de Pós-Graduação em Biodiversidade e Conservação da Natureza, da Universidade Federal de Juiz de Fora como requisito parcial para obtenção do título de Doutor em Biodiversidade e Conservação da Natureza. Área de concentração: Processos Ecológicos e Conservação da Natureza.
\end{abstract}

Orientador: Prof. Dr. Roberto da Gama Alves

Coorientador: Prof. Dr. Cézar Henrique Barra Rocha

Juiz de Fora 
Ficha catalográfica elaborada através do programa de geração automática da Biblioteca Universitária da UFJF, com os dados fornecidos pelo (a) autor (a)

Amaral, Pedro Henrique Monteiro do.

Nascentes tropicais em áreas de silvicultura do eucalipto: estrutura e composição de Ephemeroptera, Plecoptera e Trichoptera (Insecta) / Pedro Henrique Monteiro do Amaral. -- 2021.

$98 \mathrm{f}$.

Orientador: Roberto da Gama Alves

Coorientador: Cézar Henrique Barra Rocha

Tese (Doutorado) - Universidade Federal de Juiz de Fora, Instituto de Ciências Biológicas. Programa de Pós Graduação em Biodiversidade e Conservação da Natureza, 2021.

1. Nascente. 2. Eucalipto. 3. Insetos aquáticos. 4. Diversidade funcional. 5. Diversidade beta I. Alves, Roberto da Gama, orient. II. Rocha, Cézar Henrique Barra, coorient. III. Título. 


\section{"Nascentes tropicais em áreas de silvicultura do eucalipto: estrutura e composição de Ephemeroptera, Plecoptera e Trichoptera (Insecta)”.}

\section{Pedro Henrique Monteiro do Amaral}

Orientador: Prof. Dr. Roberto da Gama Alves

Coorientador: Prof. Dr. Cézar Henrique Barra Rocha

Tese apresentada ao Instituto de

Ciências Biológicas, da

Universidade Federal de Juiz de

Fora, como parte dos requisitos para obtenção do Título de doutor em Biodiversidade e Conservação da Natureza.

Aprovado em 27 de agosto de 2021.

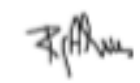

Prof. Dr. Roberto da Gama Alves

Universidade Federal de Juiz de Fora - UFJF

\begin{tabular}{|c|}
\hline $\begin{array}{l}\text { Prof. Dr. Cézar Henrique Barra Rocha } \\
\text { Universidade Federal de Juiz de Fora - UFJF }\end{array}$ \\
\hline 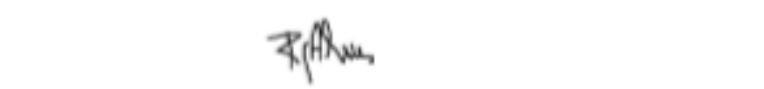 \\
\hline
\end{tabular}

Prof. Dr. Renato Tavares Martins

Instituto Nacional de Pesquisas da Amazônia- INPA

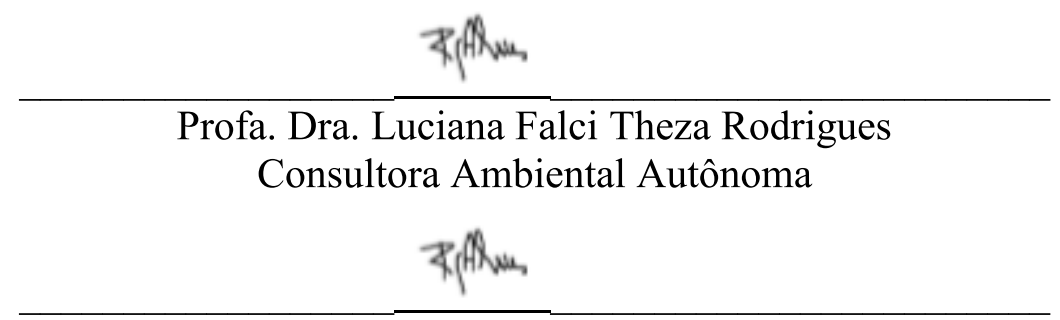

Profa. Dra. Simone Jaqueline Cardoso

Universidade Federal de Juiz de Fora - UFJF

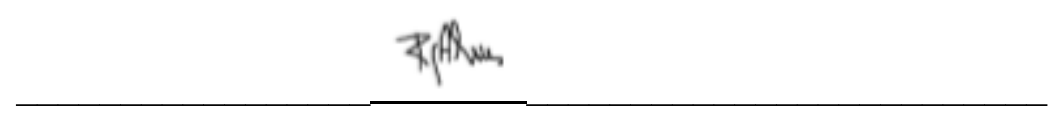

Prof. Dr. Miguel Fernandes Felippe

Universidade Federal de Juiz de Fora - UFJF 
Planeta Água

Água que nasce na fonte Serena do mundo E que abre um profundo grotão Água que faz inocente Riacho e desagua

Na corrente do Ribeirão

Águas escuras dos rios Que levam a fertilidade ao sertão Águas que banham aldeias E matam a sede da população

Águas que caem das pedras

No véu das cascatas

Ronco de trovão

E depois dormem tranquilas

No leito dos lagos

No leito dos lagos

Água dos igarapés

Onde Iara mãe d'água

É misteriosa canção

Água que o sol evapora

Pro céu vai embora

Virar nuvens de algodão

Gotas de água da chuva

Alegre arco-iris

Sobre a plantação

Gotas de água da chuva

Tão triste são lágrimas

$\mathrm{Na}$ inundação

Águas que movem moinhos

São as mesmas águas

Que encharcam o chão

E sempre voltam humildes

Pro fundo da terra

Pro fundo da terra

Terra! Planeta água Terra! Planeta água...

(Guilherme Arantes) 


\section{AGRADECIMENTOS}

Primeiramente agradeço a Deus, pelo dom da vida e por ter me dado sabedoria, proteção e força para vencer cada obstáculo. Obstáculos estes que me fizeram crescer e concluir esta importante etapa da minha vida.

Ao meu querido pai Harley, que tenho certeza que do céu acompanhou feliz esta importante etapa da minha vida e a minha querida mãe Janeth, por todo amor e incentivo durante minha vida. Amo vocês!

A minha esposa Karla, por todo amor, carinho e apoio durantes todos esses anos juntos. Amo você!

A minha irmã Paula e as minhas sobrinhas Valentina e Manuela, por terem alegrado minha vida durante esta jornada. Amo vocês!

Ao meu orientador, Prof. Dr. Roberto da Gama Alves, por ter sido durante toda esta minha jornada acadêmica um excelente orientador. Obrigado pela amizade, incentivo, oportunidade, confiança e por todo conhecimento compartilhado. Você é e sempre será um exemplo a ser seguido. Obrigado por tudo!

Ao meu Coorientador, Prof. Dr. Cézar Henrique Barra Rocha, pela amizade, dedicação e contribuição na construção desta tese. Obrigado por tudo!

Aos senhores Leonardo, Elisier e Manoel, proprietários das respectivas fazendas de eucalipto, que gentilmente proporcionaram que a pesquisa pudesse ser realizada em sua propriedade e liberaram seus funcionários para nos acompanhar. Muito Obrigado!

Aos senhores Jorge, Jésus e Ronaldo, funcionários das fazendas que por diversas vezes nos guiaram no campo e nos ajudaram a encontrar as nascentes, sem vocês nosso trabalho teria sido muito mais árduo. Muito Obrigado!

A todos meus colegas do laboratório de Invertebrados Bentônicos (LIB/UFJF) pela amizade e contribuição nas coletas de campo. Muito Obrigado!

Ao pesquisador do Núcleo de Análise Geo Ambiental (NAGEA/UFJF) Micael Marlon por toda ajuda na confecção dos mapas. Muito obrigado!

Aos professores do Doutorado pelas disciplinas, que nos ensinaram a ser melhores profissionais e pesquisadores. Muito Obrigado!

A todos os funcionários do Programa de Pós-Graduação em Biodiversidade e Conservação da Natureza, em especial as funcionárias da secretária Marlú, Dayane e Priscila pelas instruções dadas ao longo destes anos. Muito Obrigado! 
Agradeço ao laboratório de Ecologia Aquática (LEA/UFJF) pelos dados de nutrientes da água, e ao Laboratório de Climatologia e Análise Ambiental (LabCAA/UFJF) pelos dados fornecidos de precipitação para a região de Juiz de Fora, MG. Muito Obrigado!

À Universidade Federal de Juiz de Fora (UFJF/MG), pela bolsa concedida pelo Doutorado e por fazer parte da minha história. Muito Obrigado! 


\section{RESUMO}

As nascentes são ecossistemas de importância ecológica, econômica e social. Entretanto, tendo em vista a expansão das atividades agrícolas em regiões tropicais, a pressão sobre esses ecossistemas tem aumentado. Apesar de sua importância, nascentes tropicais em áreas com diferente uso da terra são pouco estudadas. Portanto, esta tese, que está estruturada em três capítulos, ela tem como objetivo geral ampliar o conhecimento acerca do impacto de áreas cultivadas com eucalipto e da sazonalidade pluviométrica em nascentes tropicais da Mata Atântica brasileira, com base na estrutura e composição das assembleias de Ephemeroptera, Plecoptera e Trichoptera (EPT). No primeiro capítulo, verificamos se a composição granulométrica do sedimento nas nascentes em áreas de floresta difere de nascentes em áreas plantadas com eucalipto, uma vez que a conversão de florestas naturais pode promover mudanças na composição do sedimento em ambientes aquáticos. Foi possível observar que as nascentes em áreas de floresta estiveram associadas com areia muito grossa, enquanto aquelas em área de eucalipto estiveram associadas a partículas de granulometria mais fina, o que enfatiza a importância da vegetação ciliar para mitigar potenciais impactos da silvicultura do eucalipto no sedimento das nascentes. No segundo capítulo, utilizamos a estrutura taxonômica e funcional de EPT com o objetivo de verificar o impacto da silvicultura do eucalipto sobre a fauna de nascentes neotropicais. Nossos resultados mostraram que nascentes em área de eucalipto apresentaram redução da riqueza e mudança na composição de gêneros de EPT em comparação com nascentes em áreas de floresta. Também verificamos que o traço tamanho corporal e tipo de respiração foram as características funcionais mais influenciadas pelas variáveis ambientais em nascentes, tanto em áreas de eucalipto quanto de floresta. A redução e homogeneização da vegetação ciliar reduziram a qualidade do substrato vegetal, levando a perda de riqueza e alteração dos traços funcionais de EPT em nascentes em áreas de eucalipto. No terceiro capítulo, empregamos a diversidade beta e os componentes, substituição (turnover) e perda de espécies (aninhamento) das assembleias de EPT para verificar a influência dos períodos sazonais secos e chuvosos na estabilidade ambiental de nascentes em áreas de floresta e áreas de eucalipto. As nascentes apresentaram estabilidade ambiental entre os períodos secos e chuvosos, não havendo variação significativa da diversidade beta em ambas as áreas, e devido à heterogeneidade de habitats das nascentes a substituição de espécies foi predominante. Verificamos também 
homogeneidade dos parâmetros ambientais entre os períodos secos e chuvosos, e apesar da baixa variação da diversidade beta a variável areia fina em áreas de floresta, condutividade e turbidez em áreas de eucalipto foram as melhores preditoras. Acreditamos que os estudos contidos nesta tese contribuíram para ampliar o conhecimento da influência do uso da terra sobre as nascentes tropicais brasileiras, assim como, aponta para a necessidade de assegurar a preservação da proporção da vegetação ciliar, a fim de evitar alterações nas condições naturais do ecossistema de nascente.

Palavras-chave: EPT; granulometria; diversidade taxonômica, diversidade funcional; diversidade beta; insetos aquáticos. 


\begin{abstract}
Springs are ecosystems of ecological, economic and social importance. However, in view of the expansion of agricultural activities in tropical regions, the pressure on these ecosystems has increased. Despite their importance, tropical springs in areas with different land use are poorly studied. Therefore, this thesis, which is structured in three chapters, aims to broaden the knowledge of the impact of areas cultivated with eucalyptus and rainfall seasonality in Brazilian tropical springs, based on the structure and composition of Ephemeroptera, Plecoptera and Trichoptera assemblages (EPT). In the first chapter, we verified whether the particle size composition of sediment from springs in forest areas differs from springs in areas planted with eucalyptus, since the conversion of natural forests can promote changes in the composition of sediment in aquatic environments. It was possible to observe that springs in forest areas were associated with very coarse sand, while those in eucalyptus areas were associated with finer particle size particles, which emphasizes the importance of riparian vegetation to mitigate potential impacts of eucalyptus forestry on the sediment from the springs. In the second chapter, we use the taxonomic and functional structure of EPT in order to verify the impact of eucalyptus forestry on the environmental quality of neotropical springs. Our results showed that springs in eucalyptus areas showed reduced richness and change in the composition of EPT genera compared to springs in forest areas. We also verified that respiration and body size were the functional traits most influenced by abiotic variables in springs both in eucalyptus and forest areas. The reduction and homogenization of riparian vegetation reduced the quality of the plant substrate, leading to loss of richness and alteration of the functional traits of EPT in springs in eucalyptus areas. In the third chapter, we employ the beta diversity and components, replacement (turnover) and loss of species (nestedness) of EPT assemblages to verify the influence of dry and rainy seasonal periods on the environmental stability of springs in forest areas and eucalyptus areas. The springs showed environmental stability between the dry and rainy periods, with no significant variation in beta diversity in both areas, and due to the heterogeneity of habitats in the springs, species turnover was predominant. We also verified homogeneity of environmental parameters between the dry and rainy periods, and despite the low variation of beta diversity, the fine sand variable, conductivity and turbidity were the best predictors in forest and eucalyptus areas, respectively. We believe that the studies contained in this thesis have contributed to
\end{abstract}


broadening the knowledge of the influence of land use on Brazilian tropical springs, as well as pointing to the need to ensure the preservation of the proportion of riparian vegetation, in order to avoid changes in the natural conditions of the spring ecosystem.

Keywords: EPT; granulometry; taxonomic diversity, functional diversity; beta diversity; aquatic insects. 


\section{LISTA DE ILUSTRAÇÕES}

FIGURA 1 - Modelo esquemático da formação dos três ecótonos das nascentes, bem como suas respectivas zonas de transição.

FIGURA 2 - Nascentes estudadas nas áreas de floresta (F) e nascentes estudadas nas áreas de eucalipto $(\mathrm{E})$. 20

FIGURA 3 - Localização das áreas A, B, C e D e nascentes (A1, A2, A3, A4, A5, A6 e A7), (B1, B2, B3, B4, B5, B6, B7 e B8), (C1, C2, C3 e C4) e (D1), distribuídas em áreas de eucalipto (triângulo) e área de floresta (círculo) na bacia hidrográfica do rio Paraíba do Sul, estado de Minas Gerais, Brasil.

FIGURA 4 - Substrato presente em nascentes em áreas de eucalipto (A e B) e áreas de floresta (C), na bacia hidrográfica do Rio Paraíba do Sul, Sudeste do Brasil. 32 FIGURA 5 - Análise de Componentes Principais (PCA) considerando as frações granulométricas, matéria orgânica e cobertura vegetal de nascentes em áreas de eucalipto e áreas de floresta na bacia hidrográfica do rio Paraíba do Sul, sudeste do Brasil. .35

FIGURA 6 - Gráfico de barras de Barchart com o valor médio da composição granulométrica, matéria orgânica e cobertura vegetal de nascentes em áreas de eucalipto e áreas de floresta na bacia hidrográfica do rio Paraíba do Sul, sudeste do Brasil. .36

FIGURA 7 - Mapa do Brasil mostrando o estado de Minas Gerais e destacando a localização das propriedades A, B, C e D e nascentes (A1, A2, A3, A4, A5, A6 e A7), (B1, B2, B3, B4, B5, B6, B7 e B8), (C1, C2, C3 e C4) e (D1), distribuídos em áreas de eucalipto e floresta.

FIGURA 8 - (A) Riqueza taxonômica, (B) riqueza estimada, (C) riqueza funcional, (D) equitabilidade funcional e (E) dispersão funcional de Ephemeroptera, Plecoptera e Trichoptera em nascentes em áreas de eucalipto e áreas de floresta. .56 FIGURA 9 - Análise de Redundância (RDA) considerando as variáveis ambientais e as categorias de características funcionais de Ephemeroptera, Plecoptera e Trichoptera em nascentes em áreas de eucalipto e de floresta.

FIGURA 10 - Localização das nascentes em áreas de floresta e nascentes em área de eucalipto nas sub-bacias hidrográficas do rio Paraíba do Sul, estado de Minas Gerais, Brasil. 
FIGURA 11 - Média mensal de janeiro a dezembro da precipitação pluviométrica dos anos de 2017, 2018, 2019 e 2020 para a região de Juiz de Fora, sudeste do Brasil........78 FIGURA 12 - Análises multivariadas do diagrama de dispersão mostrando a variabilidade da composição das assembleias de Ephemeroptera, Plecoptera e Trichoptera de nascentes em áreas de floresta e áreas de eucalipto nos períodos secos $\mathrm{e}$ chuvosos. A e B: presença/ausência; C e D: abundância................................................83 FIGURA 13 - Análises multivariadas do diagrama de dispersão mostrando a variabilidade das variáveis ambientais de nascentes em áreas de floresta e áreas de eucalipto nos períodos secos e chuvosos .84 


\section{LISTA DE TABELAS}

TABELA 1 - Área, uso da terra e Área de Preservação Permanente (APP) das 20 nascentes estudadas na bacia hidrográfica do Rio Paraíba do Sul, Sudeste do Brasil....33 TABELA 2 - Teste $\mathrm{t}$, valores médios e desvio padrão da composição granulométrica e cobertura vegetal de nascentes em área de eucalipto e área de floresta na bacia hidrográficas do rio Paraíba do Sul, sudeste do Brasil.....................................................36

TABELA 3 - Área, uso da terra, altitude e Área de Preservação Permanente (APP) das 20 nascentes estudadas na bacia hidrográfica do Rio Paraíba do Sul, Sudeste do Brasil

TABELA 4 - Características funcionais e códigos utilizados para os 17 gêneros de Ephemeroptera, Plecoptera e Trichoptera coletados nas 20 nascentes estudadas na bacia hidrográfica do Rio Paraíba do Sul, Sudeste do Brasil. .52

TABELA 5 - Abundância de Ephemeroptera, Plecoptera e Trichoptera coletada em 12 nascentes em áreas de eucalipto e $8 \mathrm{em}$ áreas de floresta na bacia hidrográfica do rio Paraíba do Sul, sudeste do Brasil. .55

TABELA 6 - Resultado da análise de espécies indicadoras (IndVal), para nascentes em áreas de eucalipto e floresta na bacia hidrográfica do rio Paraíba do Sul, Sudeste do Brasil

TABELA 7 - Análise de Percentual de Similaridade (SIMPER) com listagem dos 10 primeiros táxons de Ephemeroptera, Plecoptera e Trichoptera mais abundantes nos períodos secos e chuvosos de nascentes em áreas de floresta e eucalipto da bacia do Rio Paraíba do Sul, Sudeste do Brasil

TABELA 8 - Valores de diversidade beta total $(\beta$ sor) e seus componentes substituição $(\beta$ sim) e aninhamento (Bnes) para as assembleias de Ephemeroptera, Plecoptera e Trichoptera em nascentes em áreas de floresta e eucalipto em períodos secos e chuvosos

TABELA 9 - Modelo Linear Geral (GLM) com as variáveis ambientais que mais contribuíram com a variação da diversidade beta nos períodos secos e chuvosos das nascentes em áreas de floresta e eucalipto

TABELA 10 - Variáveis ambientais das nascentes em áreas de floresta e áreas de eucalipto para os períodos secos e chuvosos (Média \pm Desvio Padrão), intervalos de mínimo e máximo (Min-Max). 


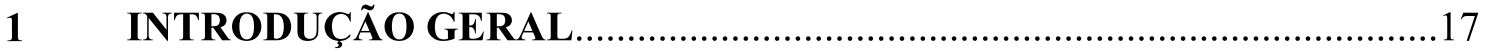

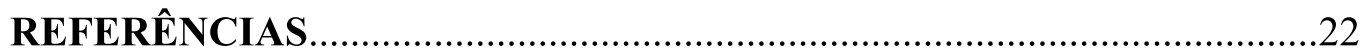

2 CAPÍTULO 1 - CARACTERIZAÇÃO GRANULOMÉTRICA DO SEDIMENTO DE NASCENTES TROPICAIS EM ÁREAS PLANTADAS

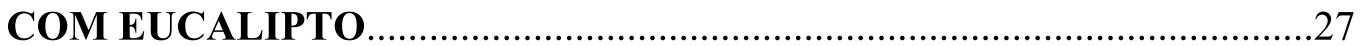

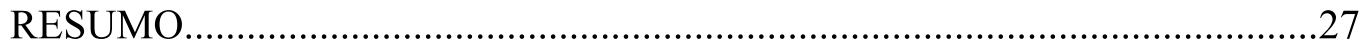

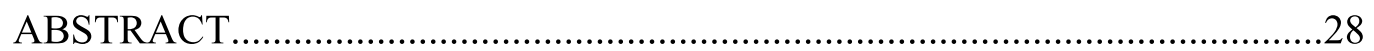

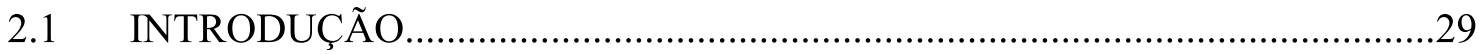

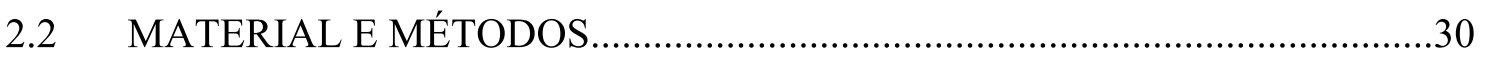

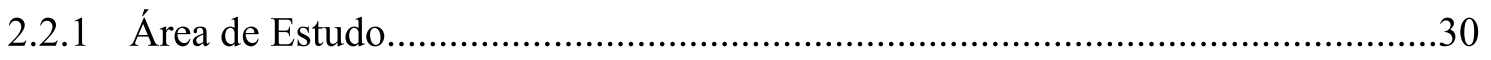

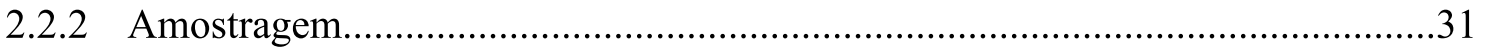

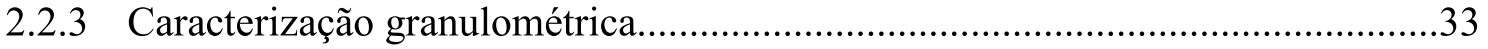

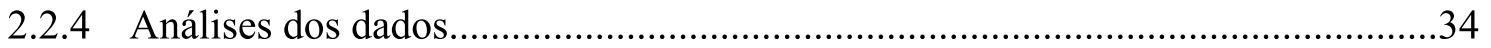

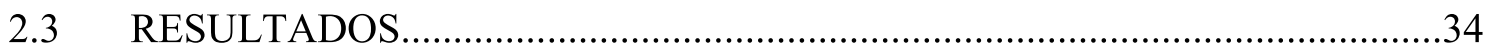

2.4 DISCUSS ÃO

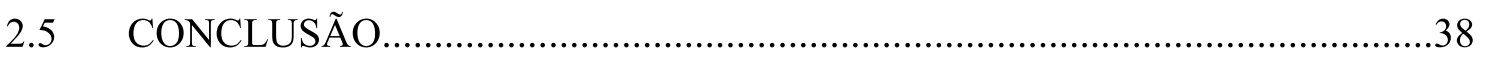

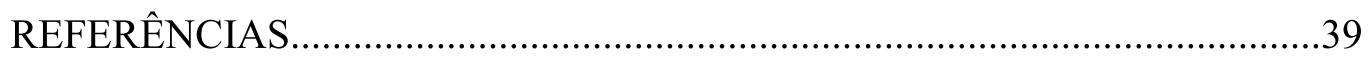

3 CAPÍTULO 2 - EFEITO DAS PLANTAÇÕES DE EUCALIPTO SOBRE A ESTRUTURA TAXONÔMICA E FUNCIONAL DAS ASSEMBLEIAS DE INSETOS AQUÁTICOS EM NASCENTES NEOTROPICAIS..................42

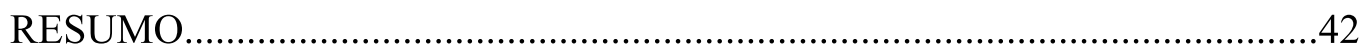

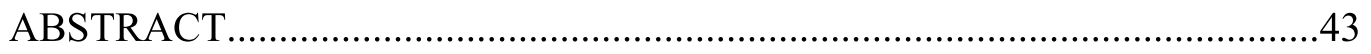

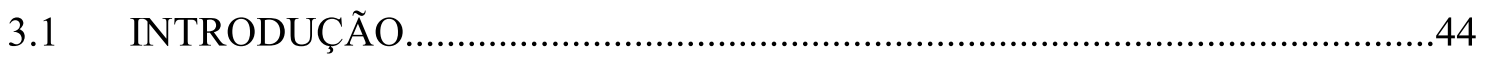

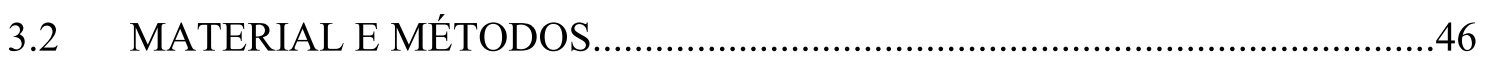

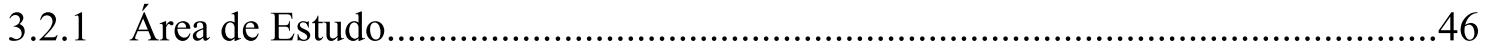

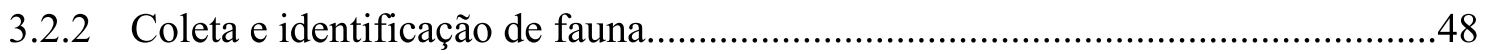

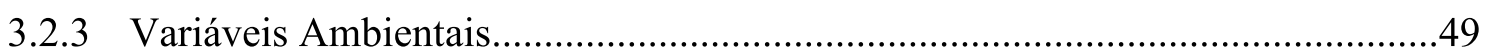

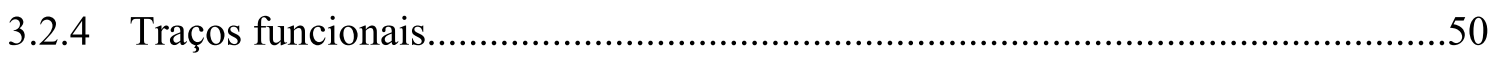

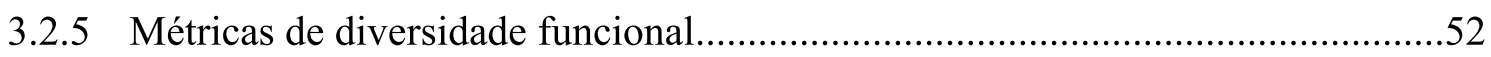




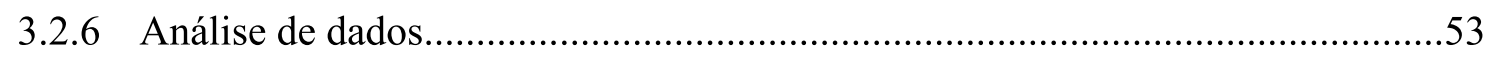

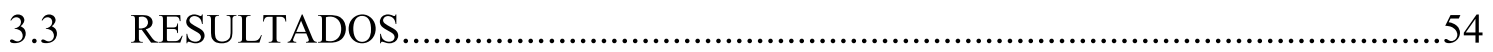

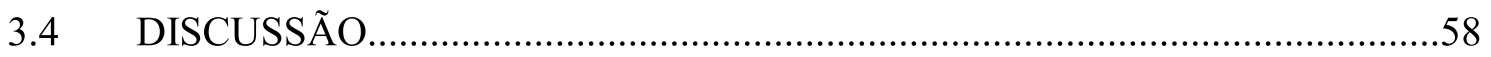

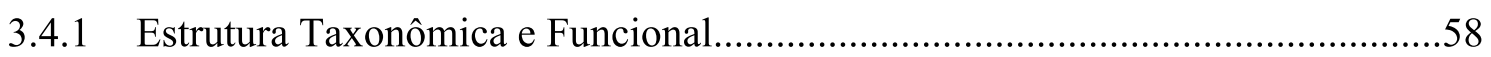

3.4.2 Variáveis Ambientais e Características Funcionais.............................................60

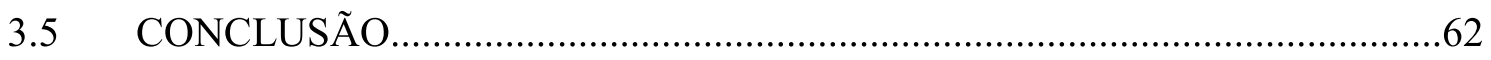

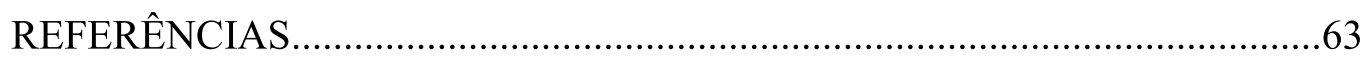

4 CAPÍTULO 3 - A VARIAÇÃO SAZONAL PLUVIOMÉTRICA EM NASCENTES TROPICAIS INFLUENCIA A DIVERSIDADE BETA DE INSETOS EM ÁREAS COM DIFERENTE USO DA TERRA? ...................71

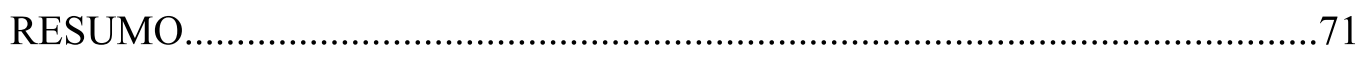

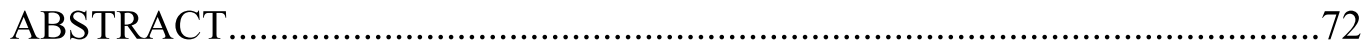

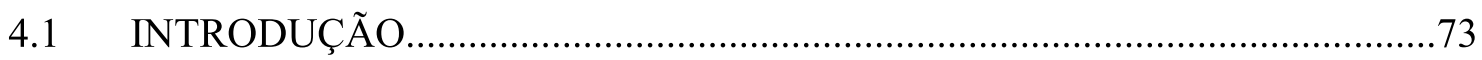

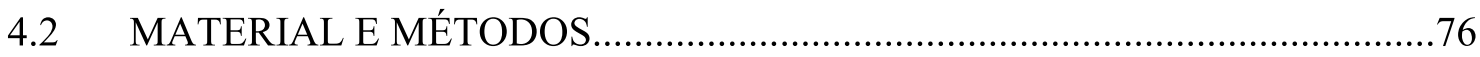

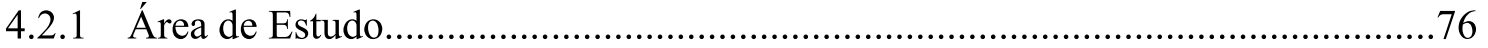

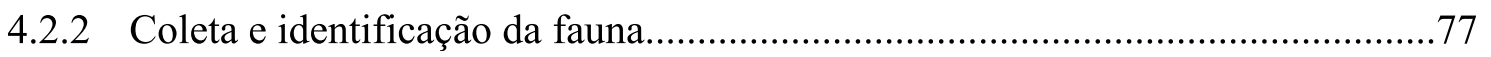

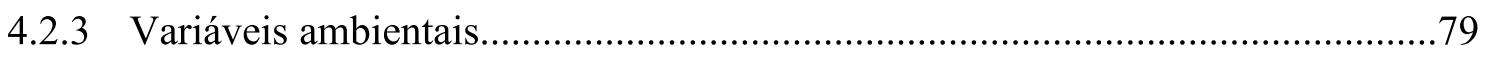

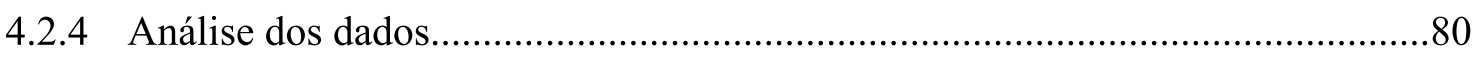

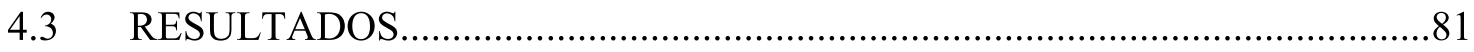

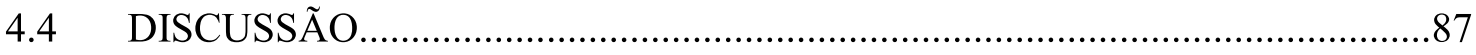

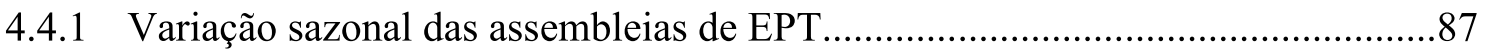

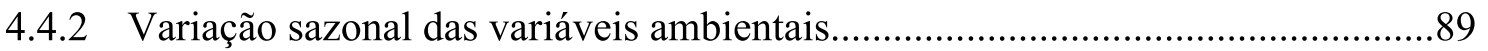

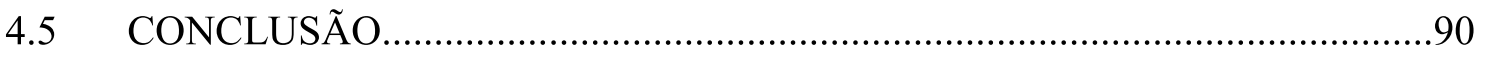

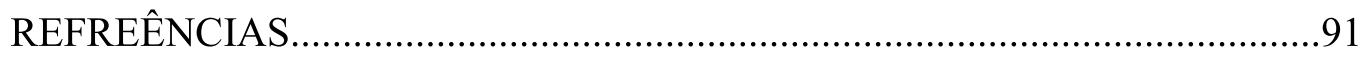




\section{INTRODUÇÃO GERAL}

As nascentes são manifestações superficiais da água subterrânea para a superfície terrestre (BARQUIN; SCARSBROOK, 2008), dando origem às redes de drenagem das bacias hidrográficas. Como tal, são ecossistemas aquáticos únicos, devido sua estrutura ecotonal entre as águas subterrâneas, águas superficiais e os ecossistemas terrestres, constituindo um ecótono de três vias (VON FUMETTI; BLATTNER, 2017) (Figura 1). Apesar de suas dimensões limitadas, apresentam elevada heterogeneidade de habitats (CANTONATI; GERECKE; BERTUZZI, 2006), contribuindo consideravelmente para a diversidade local e regional de espécies (STANFORD; WARD; ELLIS,1994; CANTONATI; GERECKE; BERTUZZI, 2006). Isto porque, a entrada de matéria orgânica vegetal aumenta a complexidade do habitat e eleva a disponibilidade de alimentos (STAUDACHER; FÜREDER, 2007), promovendo uma alta diversidade e abundância de espécies (STANFORD; WARD; ELLIS,1994).

Figura 1 - Modelo esquemático da formação dos três ecótonos das nascentes, bem como suas respectivas zonas de transição.

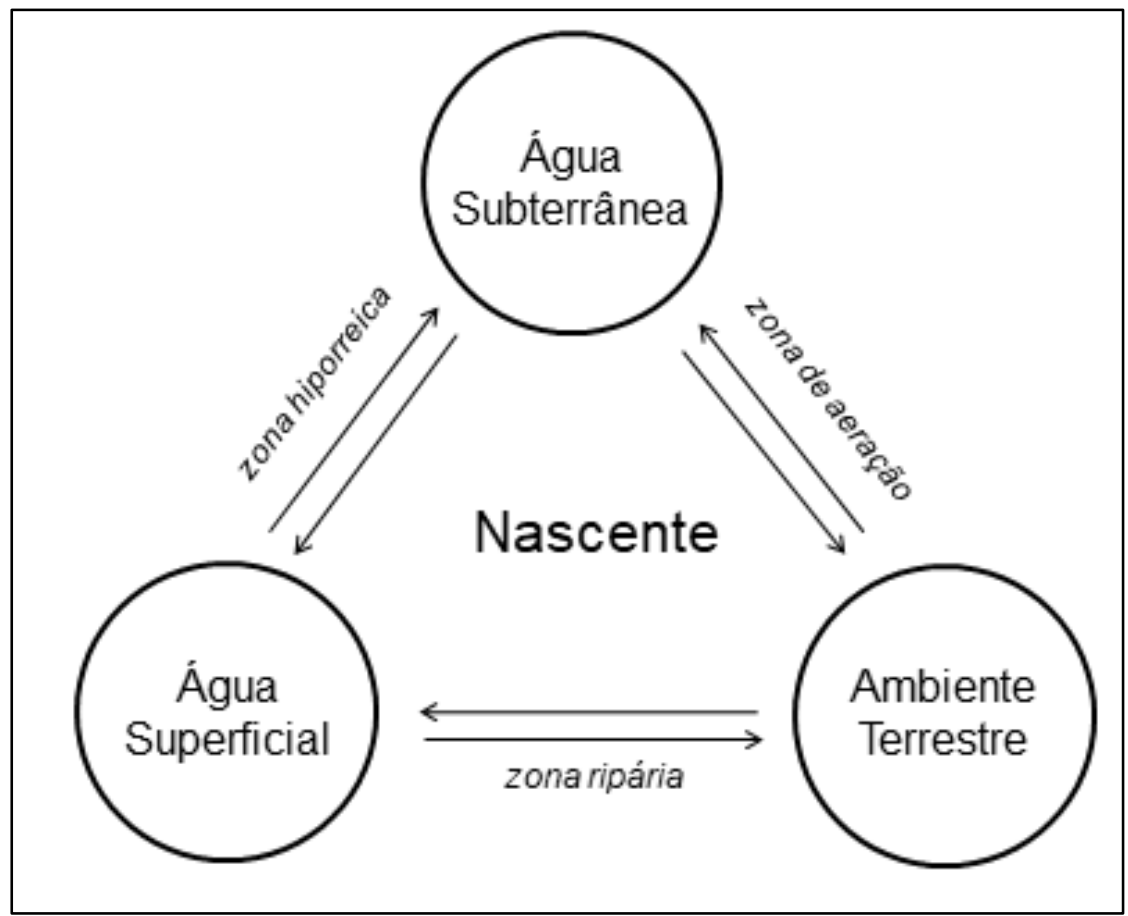

Fonte: Adaptado de Scarbrook et al. (2007).

Além disso, ecossistemas de nascente podem apresentar-se como ambientes ecologicamente estáveis (VAN DER KAMP, 1995; ABDELSALAM; TANIDA, 2013), 
principalmente devido à sua constância térmica (CANTONATI; GERECKE; BERTUZZI, 2006) e estabilidade do fluxo de água (SMITH; WOOD; GUNN, 2003). Contudo, períodos sazonais secos e chuvosos são fatores temporais importantes na estabilidade e permanência das espécies que habitam nascentes (MYERS; RESH, 2002), principalmente em regiões tropicais, caracterizadas por forte sazonalidade de clima, com estações secas e chuvosas pronunciadas (HERNANDEZ; LOPEZ, 1998). Flutuações sazonais temporais exercem alterações nos principais parâmetros associados à distribuição das comunidades aquáticas como disponibilidade de microhabitats, fluxo de água e condições físicas e químicas da água (ZARDO et al., 2013). De acordo com Smith; Wood; Gunn (2003), períodos prolongados de estiagem e fortes chuvas podem alterar o fluxo de água, influenciando diretamente a composição da fauna bentônica de nascentes. A variação temporal das condições ambientais pode ser mais pronunciada em ambientes aquáticos sujeitos à influência de atividade antrópica (MARMONTEL et al., 2018).

Nos trópicos, grandes extensões territoriais de vegetação natural foram convertidas em diferentes usos da terra (ALMEIDA et al., 2019). A Mata Atlântica, segunda maior floresta pluvial tropical do continente americano e um dos 25 hotspots mundiais de biodiversidade do mundo (TABARELLI et al., 2004), está entre os biomas mais ameaçado do planeta (MYERS et al., 2000). No Brasil, resta pouco mais de 7\% da cobertura florestal remanescente da Mata Atlântica, grande parte desta convertida em áreas de cultivo e de pastagem (ALMEIDA, 2016). A redução da vegetação natural pode causar impactos nos ecossistemas aquáticos, manifestada em alteração dos parâmetros físicos e químicos da água (RODRIGUES et al. 2018), mudanças nos fluxos de água, erosão de margens e deposição de sedimento (HICKEY; DORAN, 2004), levando à modificação da fauna bentônica, incluindo perda de espécies (BARNOSKY et al., 2011). Apesar de serem protegidas pela Lei Federal n..$^{\circ}$ 12.651/12, que institui que, as áreas do entorno das nascentes devem conter um raio mínimo de 50m de vegetação natural (Área de Preservação Permanente - APP) (BRASIL, 2012), as nascentes estão sujeitas a fortes pressões antrópicas, como por exemplo, a silvicultura do eucalipto (AMARAL; ROCHA; ALVES, 2021) (Figura 2).

Plantações de espécies introduzidas do gênero Eucalyptus têm se expandido em todo mundo, devido sua capacidade adaptativa, rápido crescimento e benefício econômico (PINTO et al., 2004), cuja madeira é utilizada para diversas finalidades (CORDERO-RIVERA; ÁlVAREZ; ÁLVAREZ, 2017). A substituição de florestas 
naturais por plantações de eucalipto em regiões tropicais, têm aumentado a homogeneização e fragmentação da vegetação natural (BROCKERHOFF et al., 2013), levando à redução da riqueza e alteração da composição da fauna bentônica de nascentes (AMARAL; ROCHA; ALVES, 2021). O Brasil, por apresentar condições favoráveis de clima, solo e extensão territorial é atualmente um dos países referência em silvicultura (VALVERDE et al., 2004), tendo Minas Gerais, configurando entre os estados com a maior área plantada com espécies de eucalipto (BORGES; LEITE; LEITE, 2018). Contudo, sistemas aquáticos em áreas de floresta natural, cujas teias alimentares são sustentadas pela entrada de matéria orgânica da vegetação circundante (WALLACE et al. 1997), podem ter sua qualidade e quantidade de material vegetal comprometida, devido a modificações na vegetação da bacia hidrográfica em que estão inseridos (ABELHO; GRAÇA, 1996). De acordo com Larrañaga et al. (2009), sistemas aquáticos em áreas de eucalipto estão sujeitos à redução qualitativa e quantitativa da entrada de matéria orgânica da vegetação natural, uma das principais causas de perdas de riqueza e diminuição da abundância de insetos aquáticos nessas áreas.

Os insetos aquáticos estão entre os grupos mais diversos e abundantes destes ecossistemas (MERRIT; CUMMINS, 1996), com relevante importância nos processos ecológicos, como ciclagem de nutrientes e fluxo de energia (BALACHANDRAN et al., 2012). Entre as ordens de insetos, imaturos de Ephemeroptera, Plecoptera e Trichoptera (EPT) são frequentemente presentes em ecossistemas de nascentes (STAUDACHER; FÜREDER, 2007; SAVIĆ; DMITROVIĆ; PEŠIĆ, 2017; AMARAL; ROCHA; ALVES, 2021). Devido à sensibilidade das assembleias de EPT a mudanças ambientais, são comumente utilizadas como indicadores ecológicos de ecossistemas aquáticos (BISPO et al., 2006; ANDRADE et al. 2017; SOUZA et al., 2020) sendo abundantes e de composição diversa em águas limpas, com vegetação ciliar preservada, temperatura da água amena e alto teor de oxigênio dissolvido (BISPO; OLIVEIRA, 2007; AMARAL et al., 2015). Savić; Dmitrović; Pešić (2017), por exemplo, estudaram nascentes na Europa e verificaram que a cobertura vegetal e a temperatura da água foram fatores importantes na estruturação das assembleias de EPT. Portanto, pode-se esperar que o uso de grupos sensíveis a mudanças ambientais, como as assembleias de EPT (AMARAL et al., 2015; ANDRADE et al., 2017), pode gera respostas em relação a perturbações naturais e antrópicas em ecossistema de nascente (Figura 2). 
Figura 2 - Nascentes estudadas nas áreas de floresta (F) e nascentes estudadas nas áreas de eucalipto (E).
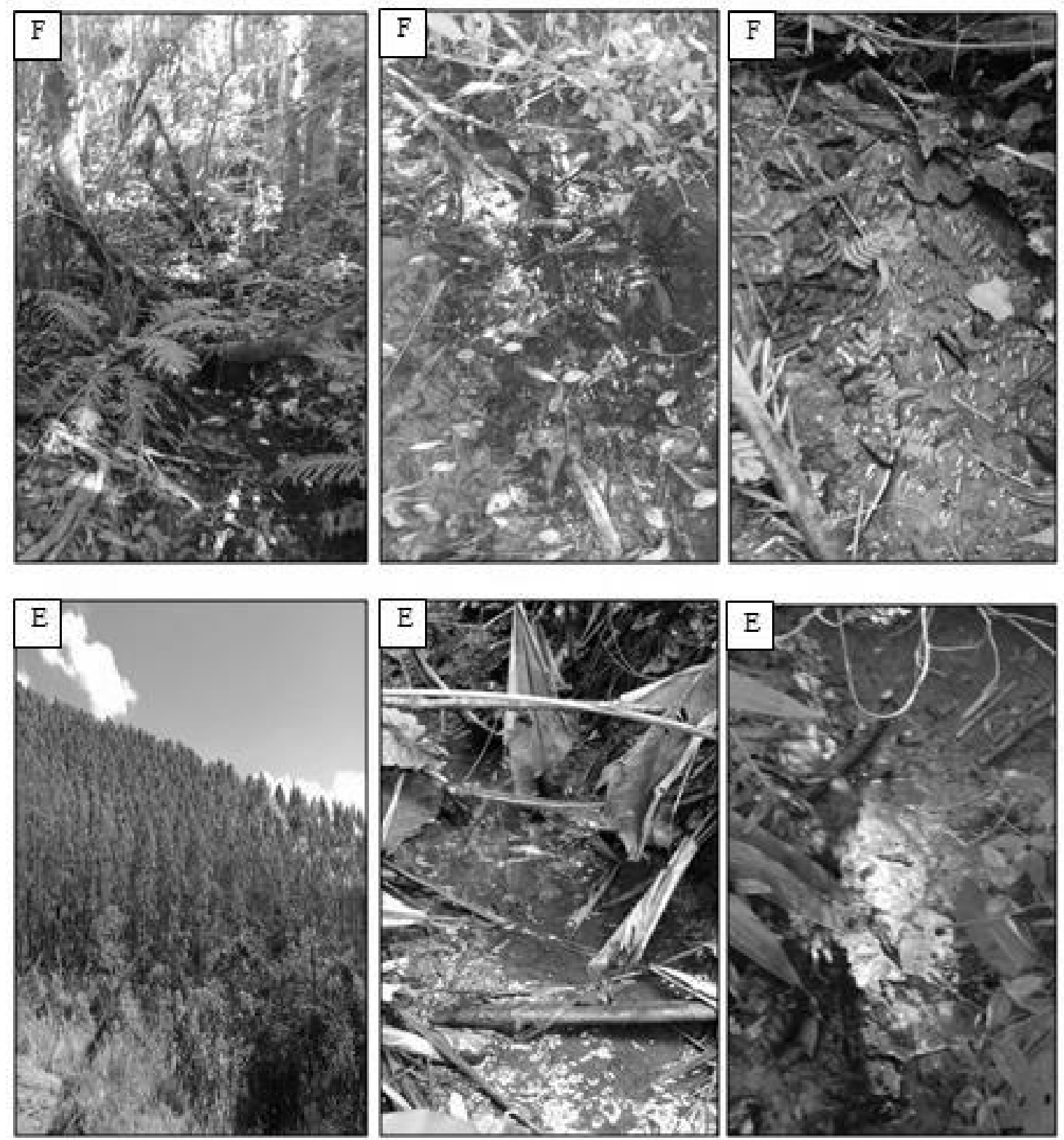

Fonte: O autor (2021).

Apesar da elevada riqueza e abundância de espécies que ocorrem em nascentes, esses ecossistemas, de maneira geral, são menos estudados que outros ecossistemas aquáticos de água doce (SMITH; WOOD; GUNN, 2003; CANTONATI; GERECKE; BERTUZZI, 2006). Ainda que o número de estudos que analisam a fauna bentônica de nascentes tenha aumentado nos últimos anos (CANTONATI et al., 2012; ABDELSALAM; TANIDA, 2013; ZHAI et al., 2020), grande parte destas pesquisas se concentram em países da Europa (VON FUMETTI et al., 2006; LENCIONI et al., 2012; LENCIONI et al., 2018) e América do Norte (MYERS; RESH, 2002; GATHMANN; 
WILLIAMS, 2006; SPRINGER; STEVENS, 2008). Frente à carência de estudos e a alta pressão humana que ameaça o estado ecológico desses ecossistemas, são necessários estudos que busquem suprir as lacunas na área do conhecimento da fauna bentônica de nascentes tropicais brasileiras, bem como entender os impactos do uso da terra e da variação temporal sobre este ecossistema.

Diante do exposto, nesta tese tratamos de como o uso da terra e a sazonalidade temporal (seca e chuva) afetam as assembleias de Ephemeroptera, Plecoptera e Trichoptera (EPT) de nascentes tropicais brasileiras, bem como o estado ecológico desse ecossistema. A tese está estruturada em três capítulos que representam artigos publicados ou em fase de preparação para posterior publicação. Em cada capítulo, objetivos específicos, relacionados às hipóteses, são apresentados.

No primeiro capítulo, testou-se a hipótese de que nascentes em áreas de eucalipto apresentam a composição granulométrica mais fina e menor porcentagem de matéria orgânica quando comparadas com nascentes em áreas de floresta natural. Esse artigo foi publicado na revista científica Ciência Florestal.

No segundo capítulo, foi testada a hipótese de que nascentes em áreas cultivadas com eucalipto, a riqueza dos táxons seria menor e a composição taxonômica e a diversidade funcional das assembleias de EPT seria diferente quando comparada às nascentes em áreas de floresta natural. Esse artigo foi publicado na revista científica Studies on Neotropical Fauna and Environment.

Por fim, no terceiro capítulo, foi testada a hipótese de que, devido à heterogeneidade e estabilidade ambiental das nascentes, a composição da assembleia de EPT seja estruturada pelo componente substituição e, períodos secos e chuvosos exerçam maior efeito na variação da diversidade beta em área de eucalipto. Esse artigo está sendo preparado para ser submetido à revista científica Ecological Indicators. 


\section{REFERÊNCIAS}

ABDELSALAM, K. M.; TANIDA, K. Diversity and spatio-temporal distribution of macro-invertebrates communities in spring flows of Tsuya Stream, Gifu Prefecture, central Japan. The Egyptian Journal of Aquatic Research, v.39 n.1, p.39-50, 2013.

ABELHO, M.; GRACA, M . A. S. Effects of eucalyptus afforestation on leaf litter dynamics and macroinvertebrate community structure of streams in Central Portugal. Hydrobiologia, v.324, p.195-204, 1996.

ALMEIDA,D. R. A.; STARK, S. C.; SCHIETTI, J.; CAMARGO, J. L. C.; AMAZONAS, N. T.; GORGENS, E. B.; ROSA, D. M.; SMITH, M. N.; VALBUENA, R.; SALESKA, S.; ANDRADE, A.; MESQUITA, R.; LAURANCE, S. G.; LAURANCE, W. F.; LOVEJOY, T. E.; BROADBENT, E. N.; SHIMABUKURO, Y. E.; PARKER, G. G.; LEFSKY, M.; SILVA, C. A.; BRANCALION, P. H. S .

Persistent effects of fragmentation on tropical rainforest canopy structure after $20 \mathrm{yr}$ of isolation. Ecological Applications, v.29, n.6, 2019.

ALMEIDA, D. S. Recuperação ambiental da Mata Atlântica. Ilhéus, Editus, 200p, 2016.

AMARAL. P. H. M,; SILVEIRA, L. S.; ROSA, B. F. J.; OLIVEIRA, V. C.; ALVES, R. G. Influence of habitat and land use on the assemblages of Ephemeroptera, Plecoptera, and Trichoptera in Neotropical streams. J. Insect. Sci., v.15, n.1, p.1-7, 2015.

AMARAL, P. H. M.; ROCHA, C. H. B.; ALVES, R. G. Effect of eucalyptus plantations on the taxonomic and functional structure of aquatic insect assemblages in Neotropical springs. Studies on Neotropical Fauna and Environment, p.1- 12, 2021.

ANDRADE, A. L.; BRASIL, L. V.; BENONE, N. L.; SHIMANO, Y.; FARIAS, A. P. J.; MONTAGA, L. F.; DOLÉDEC, S.; JUEN, L. Influence of oil palm monoculture on the taxonomic and functional composition of aquatic insect communities in eastern Brazilian Amazonia. Ecol. Indic. v.82, p.478-483, 2017.

BALACHANDRAN, C.; DINAKARAN, S.; CHANDRAN, S. M. D.;

RAMACHANDRA, T. V. Diversity and Distribution of Aquatic Insects in Aghanashini River of Central Western Ghats, India. Energy and Wetlands Research, p. 1-10, 2012.

BARNOSKY, A.D.; MATZKE, N.; TOMIYA, S.; WOGAN, G. O. U.; SWARTZ, B.; QUENTAL, T. B.; MARSHALL, C.; MCGUIRE, J. L.; LINDSEY, E. L.; MAGUIRE, K. C.; MERSEY, B.; FERRER, E. A. Hastheearth's sixth mass extinction already arrived? Nature, v.471, p.51-57, 2011.

BARQUÍN J, SCARSBROOK M. Management and conservation strategies for coldwater springs. Aquatic. Conserv. Mar. Freshw Ecosystem, v.18, n.5, p.580-591, 2008 .

BOHLE, H. W. Spezielle O” kologie. Limnische Systeme. Springer Verlag, Berlin, Heidelberg, New York, 1995. 
BORGES, M. G.; LEITE, M. E.; LEITEI, M. R. Mapeamento do Eucalipto no Estado de Minas Gerais Utilizando o Sensor Modis. Espaço Aberto, v. 8, n.1, p.53-70, 2018.

BISPO, P. C.; OLIVEIRA, L. G.; BINI, L. M.; SOUSA, K. G. Ephemeroptera, Plecoptera and Trichoptera assemblages from riffles in mountain streams of Central Brazil: environmental factors influencing the distribution and abundance of immatures. Braz. J. Biol. v.66, n.2, 2006

BISPO, P. C.; OLIVEIRA, L. G. Diversity and structure of Ephemeroptera, Plecoptera and Trichoptera (Insecta) assemblages from riffles in mountain streams of Central Brazil. Rev. Bras. Zool. v.24, p.283-293, 2007.

BRASIL. Lei n. 12.651, de 25 de maio de 2012. Diário Oficial da União, Brasília, DF, 28 maio 2012. Seção 1, p. 1.

BROCKERHOFF, E. G.; JACTEL, H. PARROTTA, J. A.; FERRAZ, S. F. B. Role of eucalypt and other planted forest in biodiversity conservation and the provision of biodiversity-related ecosystem services. For Ecol Manag. v.301, p.43-50, 2013.

CANTONATI, M.; GERECKE, R.; BERTUZZI, E. Springs of the Alps - Sensitive Ecosystems to Environmental Change: From Biodiversity Assessments to Long-term Studies. Hydrobiologia, v.562, p.59-96, 2006.

CANTONATI, M.; FÜREDER, L.; GERECKE, R.; JÜTTNER, I.; COX, E. J. Crenic habitats, hotspots for freshwater biodiversity conservation: toward an understanding of their ecology. Freshw Sci. v.31, n.2, p.463-480, 2012.

CORDERO-RIVERA, A.; ÁlVAREZ, M. A.; ÁLVAREZ, M. Eucalypt plantations reduce the diversity of macroinvertebrates in small forested streams. Anim. Biodivers. Conserv., v.40, n.1, v.87-97, 2017.

GATHMANN, F. O.; WILLIAMS, D. D. Insect emergence in Canadian coldwater springs: spatial and temporal patterns, and species-environment relationships. Ann. Limnol. - Int. J. Lim. v.42, n.3, p.143-156, 2006.

Hernandez, P. D.; Lopez, J. L. Alguno aspectos relevantes de la hidrologia del Rio Orinoco J.L. Lopez Sanchez, I.I. Saavedra Cuadra, M. Dubois Martinez (Eds.), El Rio Orinoco. Venezuela, Caracas, 138-154p, 1998

HICKEY, M. B. C.; DORAN, B. 2004. A review of the efficiency of buffer strips for the maintenance and enhancement of riparian ecosystems. Water Quality Research Journal of Canada, v.39, p.311-317.

KLØVE, B.; ALA-AHO, P.; E BERTRAND, G.; BOUKALOVA, Z.; ERTU“ RK, A.; GOLDSCHEIDER, N.; ILMONEN, J.; KARAKAYA, G.; KUPFERSBERGER, KVERNER, J.; LUNDBERG, A.; MILEUSNIC, M.; MOSZCZYNSKA, A.; MUOTKA, T.; PREDA, E.; ROSSI, P.; SIERGIEIEV, D.; SIMEK, J.; WACHNIEW, P.; ANGHELUTA, V.; WIDERLUND, A. Groundwater dependent ecosystems. Part I: hydroecological status and trend. Environmental Sci. Poli. v.14, p.770-781, 2011. 
LARRAÑAGA, A.; BASAGUREN, A.; ELOSEGI, A.; POZO, J. Impacts of Eucalyptus globules plantations on Atlantic streams: changes in invertebrate density and shredder traits. Fund Appl Limnol Archiv für Hydrol. v.175, n.2, p.151-160, 2009.

LENCIONI, V.; MARZIALI, L.; ROSSARO, B. Chironomids as bioindicators of environmental quality in mountain springs. Freshwater Science, v. 31, n. 2, p. 525-541, 2012.

LENCIONI, V.; MEZZANOTTE, E.; SPAGNOL, C.; LATELLA, L. Effects of human impacts on diversity and distribution of chironomids (Diptera: Chironomidae) in prealpine springs. J. Limnol. v.77, p.203-212, 2018.

MARMONTEL, C. V. F.; LUCAS-BORJA, M. E.; RODRIGUES, V. A.; ZEMA, V. A. Effects of land use and sampling distance on water quality in tropical headwater springs (Pimenta creek, São Paulo State, Brazil). Science of The Total Environment, v.622, p.680-690-701, 2018.

MERRIT, R. W.; CUMMINS, K. W. An Introduction to the Aquatic Insects of North America. Kendall/Hunt, Dubuque Iwoa, 862p, 1996.

MYERS, N.; MITTERMEIER, R.A.; MITTERMEIER, C.G.; FONSECA, G.A.B.; KENT, J. Biodiversity hotspots for conservation priorities. Nature, v.403, p.853-845, 2000 .

MYERS, N.; RESH, V. H.Trichopter richoptera and other macr a and other macroinvertebrates in springs of the Gr ates in springs of the Great Basin: species composition, richness, and distribution. Western North American Naturalist, v.62, n.1, p.1-13, 2002.

PINTO, R.; JUNIOR, J.S.Z.; ZANUNCIO, T. V.; ZANUNCIO, J. C.; LACERDA, M. C. Coleópteros coletados com armadilhas luminosas em plantios plantio de Eucalyptus urophylla na região amazônica brasileira. Ciência Florestal, v.14, n.1, p.111-119, 2004.

RODRIGUES, V.; ESTRANY, J. RANZINI, M.; CICCO, V.; MARTÍN-BENITO, J. M. T.; HEDO, J.; LUCAS-BORJAM M. E.; Effects of land use and seasonality os stream water quality in a small tropical catchment: the headwater of Córrego Água Limpa, São Paulo (Brazil). Science of the Total Environment, v.622, p.1553-1561, 2018.

SAVIĆ, A.; DMITROVIĆ, D.; PEŠIĆ, V. Ephemeroptera, Plecoptera, and Trichoptera assemblages of karst springs in relation to some environmental factors: a case study in central Bosnia and Herzegovina. Turk. J. Zool. v.41, p.119-129, 2017.

SCARSBROOK M, BARQUÍN J, GRAY D. New Zealand coldwater springs and their biodiversity. Vol. 278. Wellington, New Zealand: Department of Conservation, 2007. 
SOUZA, F.; MARIANO, R.; MOREIRA, T.; CAMPIOLO, S. Influence of the landscape in different scales on the EPT community (Ephemeroptera, Plecoptera and Trichoptera) in an Atlantic Forest region. Environmental Monitoring and Assessment, v.192, n.391, 2020.

SPRINGER, A.; STEVENS, L. Spheres of discharge of springs. Hydrogeology Journal, v.17. n.83-93, 2008.

STAUDACHER, K.; FÜREDER, L. Habitat Complexity and Invertebrates in Selected Alpine Springs (Schütt, Carinthia, Austria). Internat. Rev. Hydrobiol. v.92, n.4, p.465479, 2007.

STANFORD, J. A.; WARD, J. V.; ELLIS, B. K. 1994. Ecology of the alluvial aquifers of the Flathead River, Montana. In Gibert, J. Danielopol, D.L. and Stanford, J.A. (eds) Groundwater Ecology. Academic Press, New York, pp. 367-390.

SMITH, H.; WOOD, P. J.; GUNN, J. The influence of habitat structure and flow permanence on invertebrate communities in karst spring systems. Hydrobiologia, v.510, p.53-66, 2003.

TABARELLI, M.; PINTO, L. P.; SILVA, J. M. C.; HIROTA, M. M.; BEDÊ, L. C. Desafios e oportunidades para a conservação da biodiversidade na Mata Atlântica brasileira. Megadiversidade, v.1, n.1, 2005.

WALLACE, J. B.; EGGERT, S. L.; MEYER, J. L.; Webster, J. R. Multiple Trophic Levels of a Forest Stream Linked to Terrestrial Litter Inputs. SCIENCE, v.277, 1997.

VALVERDE SR, SOARES NS, SILVA ML, JACOVINE LAG, NEIVA SAO. 2004. comportamento do mercado da madeira de eucalipto no Brasil. Biomassa Energia, v.1, n.4, p.393-403, 2004.

VAN DER KAMP, G. The hydrogeology of springs in relation to the biodiversity of spring fauna: a review. Journal of the Kansas Entomological Society, v. 68, n. 2, p. 417, 1995.

VON FUMETTI, S.; NAGEL, P.; SCHEIFHACKEN, N.; BALTES, B. Factors governing macrozoobenthic assemblages in perennial springs in north-western Switzerland. Hydrobiologia, v.568, p.467-475, 2006.

VON FUMETTI, S.; BLATTNER, L. Faunistic assemblages of natural springs in different areas in the Swiss National Park a small-scale comparison. Hydrobiologia, v. 793, n. 1, p. 175-184, 2017.

ZARDO, D. C.; HARDOIM, E. L.; AMORIM, R.; MALHEIROS, C. H. Variação espaço-temporal naabundância de ordens e famílias de macroinvertebrados bentônicos registrados em área de nascente, Campo Verde-MT. Revista Uniara, v.16, n.1, 2013. 
ZHAI, M.; SYROVÁTKA, V. BOJKOVÁ, J.; ŠORFOVÁ, V.; POLÁŠKOVÁ, V.; SCHENKOVÁ, J. HORSÁK, M. Does predator abundance influence species diversity of equilibrium macroinvertebrate assemblages in spring fens? Freshwater Biology, v.65, p.987-998, 2020. 


\section{CAPÍTULO 1: CARACTERIZAÇÃO GRANULOMÉTRICA DO SEDIMENTO DE NASCENTES TROPICAIS EM ÁREAS PLANTADAS COM EUCALIPTO}

\section{RESUMO}

Nascentes são afloramentos do aquífero freático que formam fluxos de água importantes na prestação de serviços ecossistêmicos, como irrigação de florestas, fornecimento de água para o consumo humano e habitat para a biota aquática. No Brasil, áreas de Mata Atlântica estão sendo gradativamente substituídas por culturas de eucalipto, alterando, comumente, a composição do substrato das nascentes. O objetivo deste estudo foi verificar se a composição granulométrica do sedimento de nascentes em áreas plantadas com eucalipto difere de nascentes em áreas de floresta. A hipótese testada foi que nascentes em áreas de eucalipto apresentam diferenças na composição granulométrica e menor porcentagem de matéria orgânica quando comparadas com nascentes em áreas de floresta. Para tanto, foi coletado o sedimento de 20 nascentes perenes, todas pertencentes à bacia do rio Paraíba do Sul, situadas no estado de Minas Gerais, Brasil. Foi possível observar que as nascentes em áreas de floresta estiveram associadas com areia muito grossa, enquanto que aquelas em área de eucalipto estiveram associadas a partículas de granulometria mais fina. Em relação à matéria orgânica, não foi observada diferença significativa entre as duas áreas. O estudo enfatiza a importância da vegetação ciliar para mitigar potenciais impactos da silvicultura do eucalipto no sedimento das nascentes.

Palavras-chave: Mata Atlântica; matéria orgânica; silvicultura; vegetação ciliar. 


\begin{abstract}
Springs are discharges from groundwater that form water flows which are important in the provision of ecosystem services, such as irrigation of forests, supply of water for human consumption and the habitat for the aquatic biota. In Brazil, areas of Atlantic Forest are gradually being replaced by eucalypt crops, commonly changing the composition of the springs substrate. The objective of this study was to verify if the granulometric composition of the spring sediment in areas planted with eucalyptus differs from that of springs in forest áreas. The tested hypothesis was that springs in eucalypts areas have differences in particle size and a lower percentage of organic matter when compared to springs in forest areas. To do so, the sediment from 20 springs was collected, all belonging to the Paraíba do Sul river basin, located in the state of Minas Gerais, Brazil. It was possible to observe that springs in forest areas were associated with very coarse sand, while those in eucalyptus areas were associated with finer granulometry particles. Regarding the organic matter, no significant difference was observed between the two areas. The study emphasizes the importance of riparian vegetation to mitigate potential impacts of eucalyptus silviculture on the sediment of springs.
\end{abstract}

Keywords: Atlantic Forest; organic matter; silviculture; riparian vegetation 


\subsection{INTRODUÇÃO}

O sedimento dos ecossistemas aquáticos continentais é formado por uma grande variedade de materiais orgânicos e inorgânicos de origem autóctone e alóctone (CALLISTO; ESTEVES, 1996). Sua composição e distribuição em um corpo d'água são determinadas em grande parte pela escala e conjuntura geológica (WARD, 1992), que pode ser modificada através da entrada de grande variedade de materiais orgânicos particulados (CARNEIRO et al., 2009). No entanto, a redução e/ou conversão das florestas naturais em monoculturas pode promover mudança na composição granulométrica do sedimento (HARON et al., 1998; GRAÇA et al., 2002), devido ao aumento na entrada de sedimentos superficiais do solo (por exemplo, silte e argila) e redução na entrada de matéria orgânica particulada (HERNANI et al., 1999; SILVA et al., 2011).

Devido a sua capacidade de crescer em solos de baixa fertilidade, apresentar rápido crescimento e ampla aplicabilidade de sua madeira, espécies do gênero Eucalyptus representam atualmente grande parte das áreas plantadas no mundo (CAMARGO et al., 2004; PINTO et al., 2004). Minas Gerais está entre os estados brasileiros com maior área plantada com espécies desse gênero, sendo grande parte destinada à produção de carvão vegetal, celulose e lenha (ASSOCIAÇÃO BRASILEIRA DE PRODUTORES DE FLORESTAS PLANTADAS, 2011). A conversão de florestas nativas em cultivos mais homogêneos e espaçados como a do eucalipto pode reduzir consideravelmente a chegada da matéria orgânica oriunda da vegetação natural para os sistemas aquáticos (GRAÇA et al., 2002; LARRAÑAGA et al., 2009), assim como permitir a entrada de maior volume de sedimento fino para esses ambientes, alterando a composição granulométrica do sedimento (FRANÇA; MORENO; CALLISTO, 2006). Giam et al. (2015) verificaram em riachos tropicais na Indonésia, uma composição granulométrica mais grossa em riachos de mata nativa quando comparada com aqueles localizados em monocultura de palma.

Habitat de nascentes são ecossistemas de água doce únicos, devido às condições relativamente constantes de suas características físicas e químicas (GLAZIER, 1991; WILLIAMS; WILLIAMS; CAO, 1997). Além disso, são ambientes importantes para a prestação de serviço ecossistêmico (CANTONATI; BERTUZZI; SPITALE, 2007), como irrigação de florestas, fornecimento de água de qualidade para o consumo humano e para fauna e são habitat que abrigam grande diversidade de organismos aquáticos. No 
entanto, apesar de serem protegidas pela Lei Federal n. ${ }^{\circ}$ 12.651/12 (BRASIL, 2012), as nascentes estão sujeitas a fortes pressões antrópicas, tendo sua qualidade comprometida. Estudo sobre a composição granulométrica em nascentes assume papel importante, uma vez que possibilita evidenciar diferenças fundamentais no sedimento desses pequenos ecossistemas em áreas plantadas com eucalipto e em áreas de floresta, cujos resultados podem servir de embasamento científico para a preservação e recuperação desses mananciais.

Nesse sentido, o presente estudo verificou se a composição granulométrica do sedimento de nascentes tropicais em áreas plantadas com eucalipto difere daquelas em áreas de floresta. Testou-se a hipótese inicial de que nascentes em áreas de eucalipto apresentam a composição granulométrica mais fina e menor porcentagem de matéria orgânica quando comparadas com nascentes em áreas de floresta, dado que a silvicultura do eucalipto tende a reduzir a heterogeneidade do substrato das nascentes, devido ao acúmulo de frações mais finas do sedimento.

\subsection{MATERIAL E MÉTODOS}

\subsection{1 Área de estudo}

$\mathrm{O}$ estudo foi realizado em nascentes de quatro áreas pertencentes à bacia do rio Paraíba do Sul, situadas no estado de Minas Gerais, Brasil: A (21³7'33,12 "S e

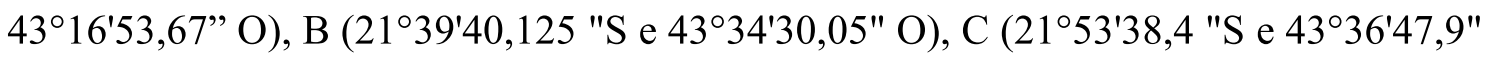
O) e D (2152'57,5 "S e 4336'13,5" O) (Figura 3). 
Figura 3 - Localização das áreas A, B, C e D e nascentes (A1, A2, A3, A4, A5, A6 e A7), (B1, B2, B3, B4, B5, B6, B7 e B8), (C1, C2, C3 e C4) e (D1), distribuídas em áreas de eucalipto (triângulo) e áreas de floresta (círculo) na bacia hidrográfica do rio Paraíba do Sul, estado de Minas Gerais, Brasil.

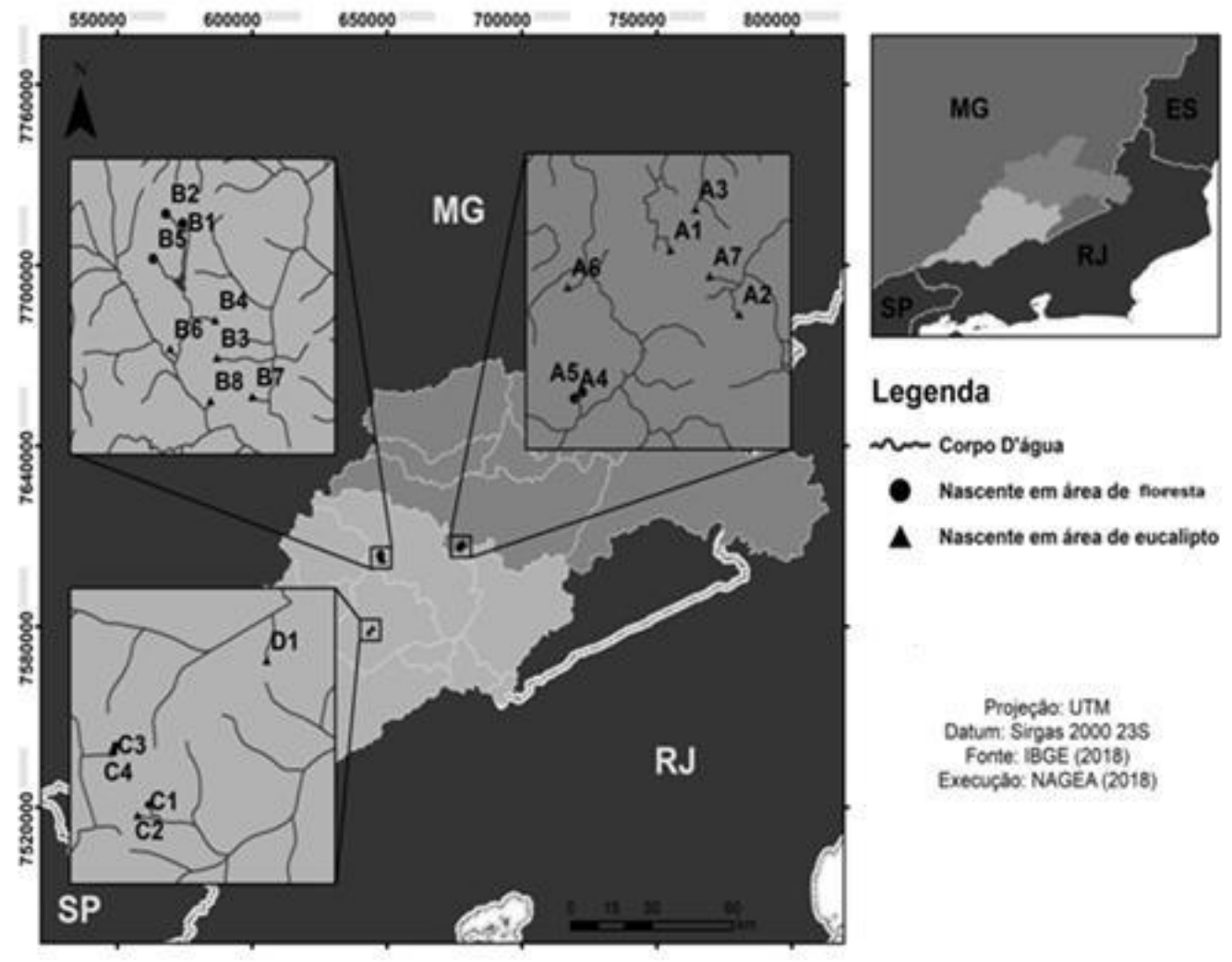

Fonte: Os Autores (2020).

O clima da região estudada é classificado como Cwb de acordo com a escala de Köppen (mesotérmico, com verões quentes e chuvosos e inverno frio e seco), com temperatura média anual de $19^{\circ} \mathrm{C}$ e altitude em torno de $850 \mathrm{~m}$ (PJF, 2004). O tipo de solo predominante para a região estudada é classificado como Latossolo VermelhoAmarelo (EMBRAPA, 1999).

\subsubsection{Amostragem}

Amostras de sedimentos superficiais $(0-10 \mathrm{~cm})$ foram coletadas na zona de exfiltração de nascentes perenes com amostrador de rede de mão (área $0.01 \mathrm{~m}^{2}$ e malha $250 \mu \mathrm{m}$ ) por $15 \mathrm{~s}$. As coletas foram realizadas uma única vez nos meses de junho, julho e agosto de 2017, correspondentes ao período de estiagem. Um total de 20 nascentes foi amostrado, oito em área de floresta e 12 em área plantada com eucalipto (Figura 4). As 
amostras foram armazenadas em sacos plásticos e levadas ao Laboratório de Invertebrados Bentônicos da Universidade Federal de Juiz de Fora (LIB/UFJF) onde se procederam as análises do estudo.

Figura 4 - Substrato presente em nascentes em áreas de eucalipto (A e B) e áreas de floresta (C) na bacia hidrográfica do Rio Paraíba do Sul, Sudeste do Brasil.
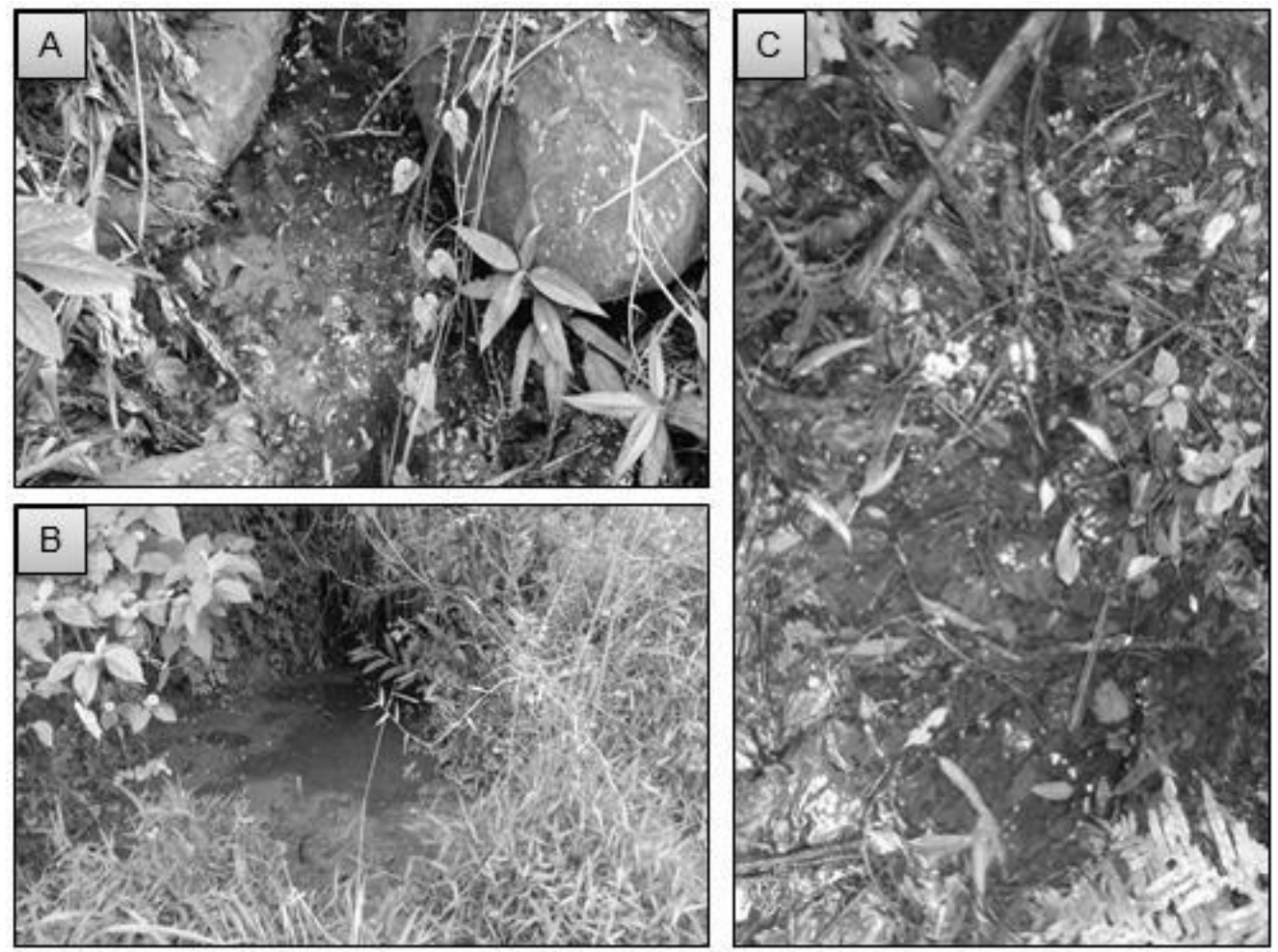

Fonte: Os autores (2020).

Todas as nascentes selecionadas para este estudo foram mapeadas via GPS modelo Garmin MAP 76CSx. O uso da terra e a cobertura vegetal para cada área foi avaliada com base em imagens de satélite de alta resolução (resolução espacial de 0,5-5 m, dados do Google Earth, GOOGLE, 2017) em um grupo de imagens multiespectrais Landsat (combinação de cores falsas RGB). Usamos o mapa gerado para descrever a contribuição das Áreas de Preservação Permanente (APP) ao redor de cada nascente, calculando a proporção de vegetação natural dentro de cada "buffer". Cada "buffer" foi delimitada como uma área circular (raio de $50 \mathrm{~m}$ ), de acordo com a Lei Federal 12.651 / 2012 (BRASIL, 2012) (Tabela 1).

O dossel foi medido através de fotografias digitais distante $10 \mathrm{~cm}$ acima da superfície de cada nascente, com câmera digital, para gerar imagens com tamanho de $4000 \times 3000$ e 12 Megapixels (Suganuma et al., 2008). As imagens geradas foram 
convertidas em preto e branco e analisadas pelo software livre ImageJ (RASBAND, 2012). O resultado obtido foi um valor médio em pixels, que variou de 0 (cobertura total) a 255 pixels (entrada total de luz). Os valores obtidos foram convertidos em porcentagem.

Tabela 1 - Área, uso da terra e Área de Preservação Permanente (APP) das 20 nascentes estudadas na bacia hidrográfica do Rio Paraíba do Sul, Sudeste do Brasil.

\begin{tabular}{|c|c|c|}
\hline \multicolumn{2}{|c|}{ Área e Uso da Terra } & \multirow{2}{*}{$\frac{\text { APP Nascente (\%) }}{23}$} \\
\hline A1 & Eucalipto & \\
\hline $\mathrm{A} 2$ & Eucalipto & 0 \\
\hline A3 & Eucalipto & 3 \\
\hline A4 & Floresta & 100 \\
\hline A5 & Floresta & 100 \\
\hline A6 & Eucalipto & 44 \\
\hline A7 & Eucalipto & 67 \\
\hline B1 & Floresta & 100 \\
\hline B2 & Floresta & 100 \\
\hline B3 & Eucalipto & 51 \\
\hline B4 & Eucalipto & 31 \\
\hline B5 & Floresta & 100 \\
\hline B6 & Eucalipto & 6 \\
\hline B7 & Eucalipto & 6 \\
\hline B8 & Eucalipto & 19 \\
\hline $\mathrm{C} 1$ & Eucalipto & 3 \\
\hline $\mathrm{C} 2$ & Floresta & 91 \\
\hline $\mathrm{C} 3$ & Floresta & 100 \\
\hline $\mathrm{C} 4$ & Floresta & 100 \\
\hline D1 & Eucalipto & 23 \\
\hline
\end{tabular}

Fonte: Os autores (2020).

\subsubsection{Caracterização granulométrica}

Para caracterização granulométrica, $120 \mathrm{~g}$ de sedimento de cada amostra seca em temperatura ambiente foi separada e peneirada em agitador de peneira (SOLOTEST), por tempo padronizado de 30 minutos e 3 de frequência, em um conjunto de peneiras de teste analítico (malha de $2 \mathrm{~mm}$ a $75 \mu \mathrm{m}$ ) e classificadas em cinco frações: areia muito grossa $(1 \mathrm{~mm}<\mathrm{x}<2 \mathrm{~mm})$, areia grossa $(500 \mu \mathrm{m}<\mathrm{x}<1 \mathrm{~mm})$, areia média $(250 \mu \mathrm{m}<\mathrm{x}<$ $500 \mu \mathrm{m})$, areia fina $(150 \mu \mathrm{m}<\mathrm{x}<250 \mu \mathrm{m})$, areia muito fina $(75 \mu \mathrm{m}<\mathrm{x}<150 \mu \mathrm{m}) \mathrm{e}$ silte/argila $(<75 \mu \mathrm{m})$ de acordo com o procedimento recomendado pela norma técnica 
NBR 7181/1982 (ABNT, 1982). Cada fração de sedimento foi pesada em balança de precisão (SHIMADZU AUY220) com saldo analítico 0,001 g.

Parte do sedimento coletado $(3 \mathrm{~g})$ de cada amostra foi separada e incinerada em mufla a $550^{\circ} \mathrm{C}$ por 4 horas para determinação do teor de matéria orgânica através da diferença entre o peso das amostras antes e depois da queima.

\subsubsection{Análises dos dados}

Todas as análises estatísticas foram realizadas no Programa R (R CORE TEAM, 2016).

Análise de Componentes Principais (PCA) foi utilizada para ordenar as nascentes segundo frações granulométricas, matéria orgânica e cobertura vegetal. O número de componentes principais (PCs) foi determinado considerando autovalores maiores que os gerados pelo método de Broken Stick. As variáveis ambientais que mais contribuíram para a formação dos eixos foram selecionadas através da análise de correlação de Pearson ( $r>0.7)$.

O teste $t$ de Student para amostras independentes foi realizado para verificar se houve diferença significativa na composição granulométrica, matéria orgânica e cobertura vegetal entre as nascentes em área de floresta e área de eucalipto. Com a finalidade de analisar a distribuição granulométrica, matéria orgânica, cobertura vegetal entre as nascentes em áreas de floresta e áreas de eucalipto foi gerada um gráfico de barras de Barchart.

\subsection{RESULTADOS}

Os dois primeiros eixos da PCA explicaram $63 \%$ da variação dos dados. O primeiro eixo explicou $46 \%$ e foi positivamente correlacionada com a areia grossa, areia média, areia fina, areia muito fina, silte e argila e nascentes em áreas plantadas com eucalipto. O segundo eixo explicou $17 \%$ dos dados e foi positivamente correlacionada com areia muito grossa, cobertura vegetal e as nascentes em áreas de floresta (Figura 5). 
Figura 5 - Análise de Componentes Principais (PCA) considerando as frações granulométricas, matéria orgânica e cobertura vegetal de nascentes em áreas de eucalipto e áreas de floresta na bacia hidrográfica do rio Paraíba do Sul, sudeste do Brasil.

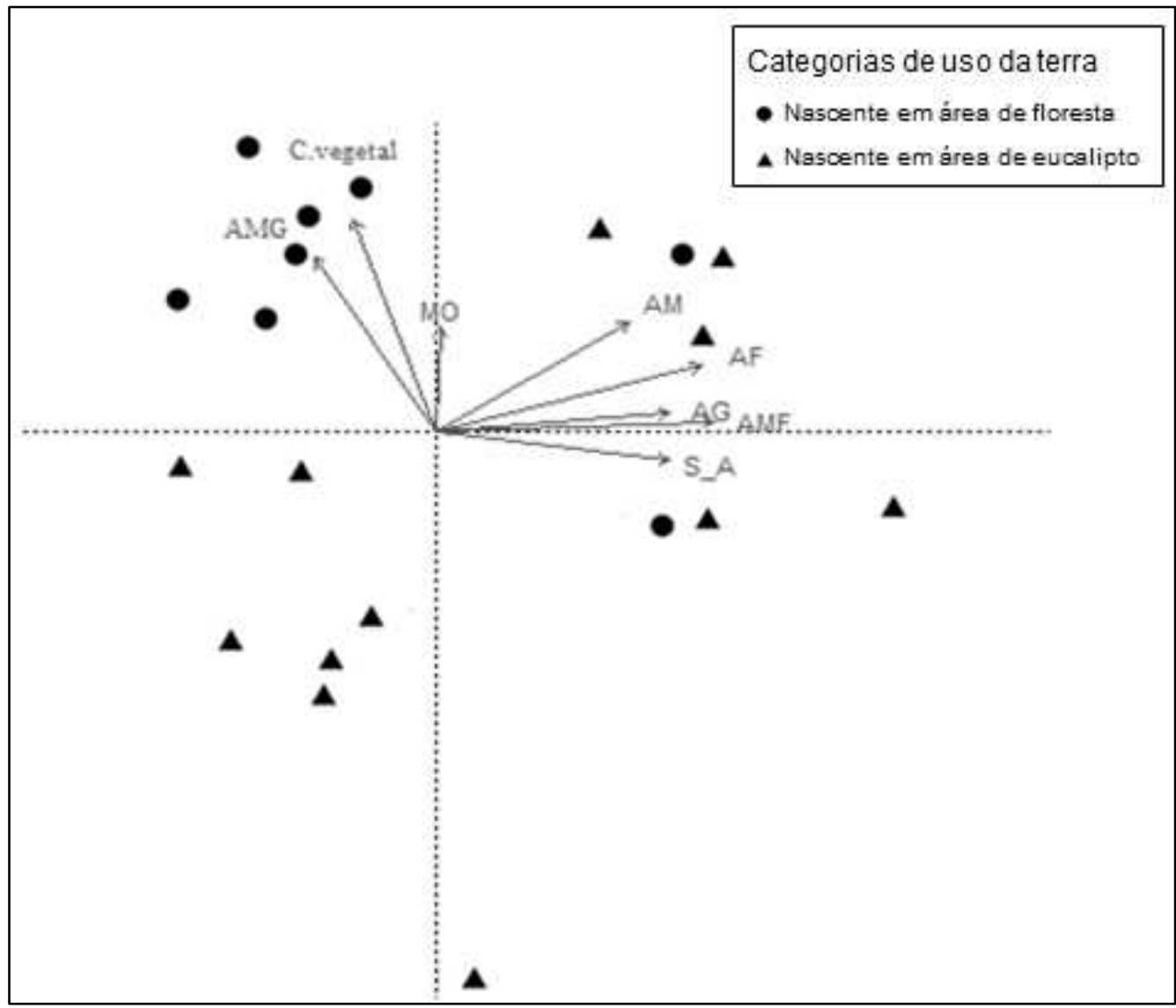

Fonte: Os autores (2020).

Em que: $\mathrm{AMG}=$ areia muito grossa; $\mathrm{AG}=$ areia grossa; $\mathrm{AM}=$ areia média; $\mathrm{AF}=$ areia fina; $\mathrm{AMF}=$ areia muito fina; $\mathrm{S}_{-} \mathrm{A}=$ silte e argila; $\mathrm{MO}=$ matéria orgânica; C.vegetal $=$ cobertura vegetal.

$\mathrm{Na}$ tabela 2 observa-se a variação da composição granulométrica, matéria orgânica e da cobertura vegetal de nascentes em área de eucalipto e em área de floresta. Foi constatada diferença significativa apenas para a areia grossa $(\mathrm{t}=2.82, \mathrm{p}<0.01)$. Os valores médios da composição granulométrica também podem ser observados na figura 6. 
Tabela 2 - Teste t, valores médios e desvio padrão da composição granulométrica e cobertura vegetal de nascentes em área de eucalipto e área de floresta na bacia hidrográfica do rio Paraíba do Sul, sudeste do Brasil.

\begin{tabular}{lccc}
\hline \multicolumn{2}{c}{ Nascentes } & Teste $t$ \\
\hline AMG & Eucalipto & Floresta & $p$-valor \\
AG & $23,87 \pm 12,05$ & $53,85 \pm 24,64$ & 0,26 \\
AM & $23,03 \pm 14,24$ & $15,11 \pm 10,51$ & 0,01 \\
AF & $11,35 \pm 8,01$ & $15,75 \pm 10,51$ & 0,81 \\
AMF & $2,86 \pm 2,29$ & $2,83 \pm 2,43$ & 0,29 \\
S_A & $1,41 \pm 1,26$ & $0,86 \pm 0,87$ & 0,09 \\
MO & $0,59 \pm 0,72$ & $0,26 \pm 0,42$ & 0,13 \\
C.vegetal & $55,67 \pm 29,62$ & $52,65 \pm 18,65$ & 0,08 \\
\hline
\end{tabular}

Fonte: Elaborado pelos autores (2020).

*Os códigos são mostrados na Figura 5.

Figura 6 - Gráfico de barras de Barchart com o valor médio da composição granulométrica, matéria orgânica e cobertura vegetal de nascentes em área de eucalipto e área de floresta na bacia hidrográfica do rio Paraíba do Sul, sudeste do Brasil.

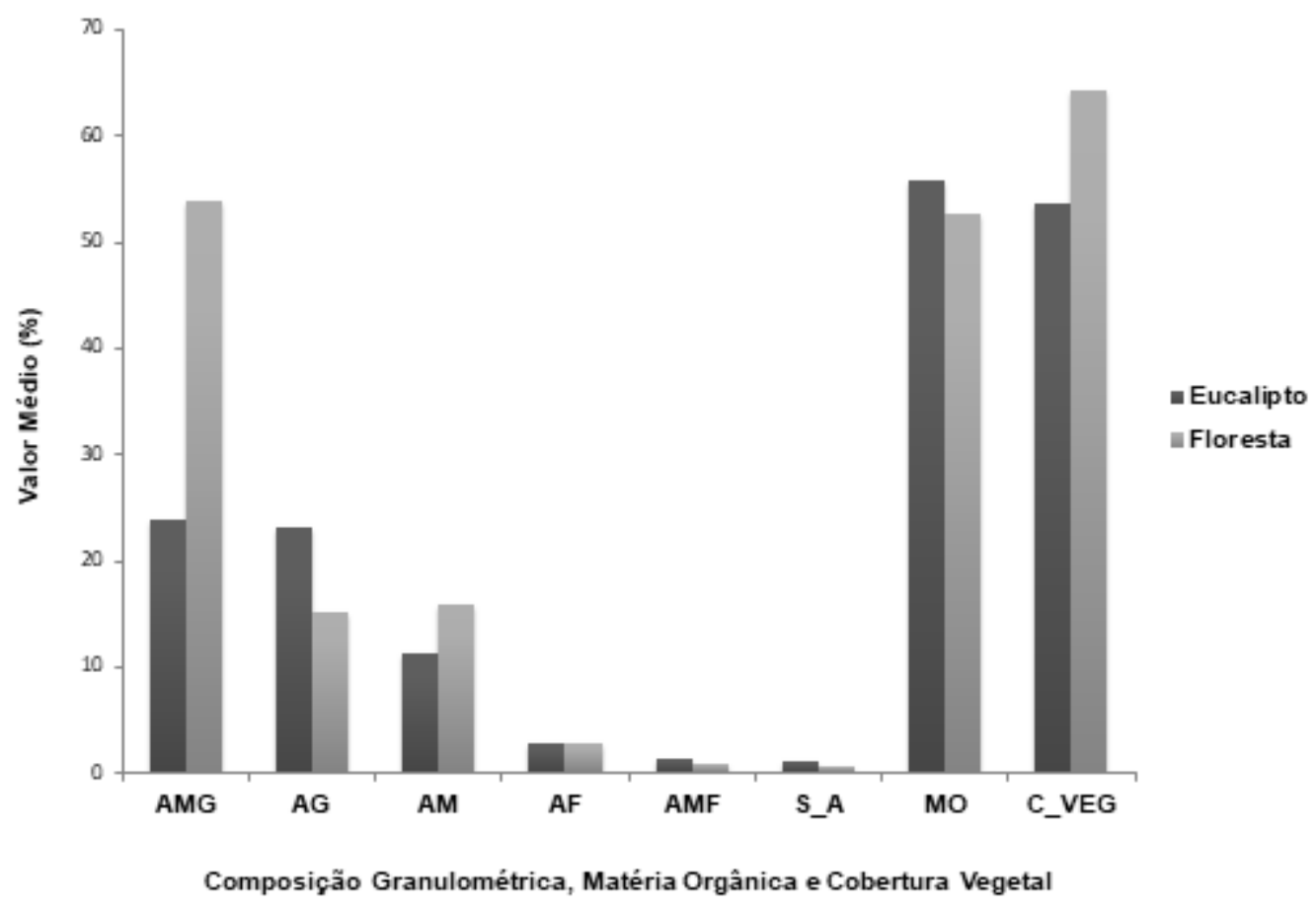

Fonte: Os autores (2020).

*Os códigos são mostrados na Figura 5. 


\subsection{DISCUSSÃO}

O carreamento, a entrada e a deposição de sedimentos de menor fração granulométrica devido ao uso da terra estão entre os impactos mais importantes sobre os sistemas aquáticos em todo o mundo (WANTZEN, 2006), por causar redução da heterogeneidade de habitats (KRUPEK; FELSKI, 2006), levando a perda da diversidade biológica destes ambientes, incluindo nascentes. Os resultados do presente estudo evidenciam maior associação de substrato muito grosso e cobertura vegetal em áreas de floresta, enquanto as nascentes em áreas de eucalipto estiveram associadas às partículas de menor granulometria. Segundo Hammes (2002) o aumento da carga de sedimentos finos nos corpos d'água provoca obstrução das brânquias de peixes, e, conforme a natureza dos sedimentos carreados, altera a composição da fauna que habita o fundo de ambientes aquáticos, de onde pouco se deslocam.

De acordo com França et al. (2006), que estudaram a composição granulométrica e sua relação com a redução da heterogeneidade ambiental pelo uso e ocupação do solo do Rio da Velhas no estado de Minas Gerais, observaram que as frações granulométricas mais grossas são predominantes nos ambientes classificados como naturais, enquanto que as frações mais finas são abundantes em trechos alterados. As taxas de erosão são mais acentuadas nas regiões tropicais submetidas à redução da cobertura vegetal (DUDGEON, 2008), intensificando o assoreamento e reduzindo o volume de água, o que provoca prejuízos e implicações ao agricultor e a biodiversidade local (EMBRAPA, 1999; KRUPEK; FELSKI, 2006). Estes resultados corroboram com a nossa hipótese inicial, que a silvicultura do eucalipto tende a reduzir a heterogeneidade ambiental, refletindo no afinamento da composição granulométrica, devido ao carreamento de partículas de menor tamanho como silte e argila para as nascentes.

Apesar de o afinamento granulométrico estar associado às nascentes em áreas de eucalipto, os resultados indicaram que a areia grossa foi à única variável significativamente afetada. Isso indica que a presença da vegetação riparia, no entorno de parte das nascentes estudadas em áreas de eucalipto, pode ter contribuído para a redução da entrada de material sedimentar fino. Segundo Resende et al. (2009) o isolamento de nascentes através do cercamento e a adequação das APPs para os $50 \mathrm{~m}$ exigidos no código florestal brasileiro (lei $\mathrm{n}^{\circ}$. 12.651/12), são ações indispensáveis para a conservação das nascentes perenes. A vegetação riparia é de fundamental importância 
não só para as nascentes como para todo corpo d'água, pois atua como barreira física impedindo a entrada excessiva de sedimentos, além de reduzir a velocidade do escoamento da água pela superfície do solo, diminuindo assim a ação da erosão e facilitando a infiltração e a recarga do lençol freático pela água.

Contrariamente à nossa hipótese inicial a matéria orgânica não esteve associada á uma área especifica. De certa forma, a manutenção da vegetação ripária associada as área de eucalipto, favorece o acúmulo de material orgânico particulado nos sistemas aquáticos (GRAÇA et al., 2002). No entanto, a qualidade desta matéria orgânica que entra nos corpos d'água pode ser de baixa qualidade nutricional (COSTA et al., 2005). Segundo Larrañaga et al. (2009), sistemas aquáticos em áreas de eucalipto estão sujeitos a uma redução qualitativa da entrada de matéria orgânica, uma das principais causas da redução da diversidade aquática nestas áreas.

\subsection{CONCLUSÃO}

A partir dos dados desse estudo foi possível observar maior associação de fração de menor granulometria em nascentes de áreas plantadas com eucalipto, corroborando nossa hipótese inicial. Por outro lado, a conservação da vegetação ripária em parte das nascentes em áreas de eucalipto, pode ter contribuído para a entrada de matéria orgânica e reduzido à chegada de material sedimentar fino. Os resultados desse estudo enfatizam a necessidade de conservação da vegetação ripária, a fim de se garantir as funções ecossistêmicas das nascentes, bem como o controle da qualidade de sua água. 


\section{REFERÊNCIAS}

ABNT - Associação Brasileira de Normas Técnicas. NBR 7182: Análise granulométrica de solos/método de ensaio. Rio de Janeiro, 1982.

ABRAF - Associação Brasileira de Produtores de Florestas Plantadas. Anuário estatístico da ABRAF. Brasília, 2010.

BRASIL. Código Florestal Brasileiro. Lei $\mathbf{n}^{\circ}$ 12.651. 2012. Disponível em: http://www.planalto.gov.br/ccivil_03/_ato2011-2014/2012/lei/112651.htm

CALISTO, M.; ESTEVES, F.A. Composição granulométrica do sedimento de um lago amazônico impactado por rejeito de bauxita e um lago natural (Pará, Brasil). Acta Limnologica Brasiliensia, Rio Claro, v.8, p. 115-126, 1996.

CAMARGO, M.L.P.; MORAES, C.B.; MORI, E.S.; GUERRINI, I. A.; MELLO, E.J.; ODA, S. Considerações sobre eficiência nutricional em Eucalyptus. Científica, Jaboticabal, v. 32, n. 2, p. 191-196, 2004.

CARNEIRO, M.A.C.; SOUZA, E.D.; REIS, E.F.; PEREIRA, H.S.; AZEVEDO, W.C. Atributos físicos, químicos e biológicos de solo de cerrado sob diferentes sistemas de uso e manejo. R. Bras. Ci. Solo, Viçosa, v. 33, p. 147-157, 2009.

CANTONATI, M.; BERTUZZI, E.; SPITALE, D. 2007. The spring habitat: biota and sampling methods. Monografie del Museo Tridentino Scienze Naturali, Trento, v.4, p. $1-350$.

CELULOSE ONLINE. MG lidera tecnologia para florestas plantadas. 2016. Disponível em: http://www. celuloseonline.com.br/pagina/pagina.asp?IDItem= 22849\&IDNoticia $=19262$

COSTA, G.S.; GAMA-RODRIGUES, A.C.; CUNHA, G.M. Decomposição e liberação de nutrientes da serapilheira foliar em povoamentos de Eucalyptus grandis no Norte Fluminense. Revista Árvore, Viçosa, v. 29, n. 9, p. 563-570, 2005.

DUDGEON, D. Tropical stream ecology. London: Academic, 2008. 370 p.

EMBRAPA - Empresa Brasileira de Pesquisa Agropecuária. Sistema brasileiro de classificação de solos. Brasília, 1999, 412 p.

FRANÇA, J.; MORENO. P.; CALLISTO, M. Importância da composição granulométrica para a comunidade bentônica e sua relação com o uso e ocupação do solo na bacia hidrográfica do rio das Velhas. In: ENCONTRO NACIONAL DE ENGENHARIA DE SEDIMENTOS, 2006, Porto Alegre. Anais... Porto Alegre: ENES, 2006.

GIAM, X.; HADIATY, R.K.; TAN, H.H.; PARENTI L. R.; WOWOR, D.; SAURI, S.; CHONG, K. Y.; YEO, D.C.J.; WILCOVE, D.S. Mitigating the impact of oil-palm monoculture on freshwater fishes in Southeast Asia. Conservation Biology, [s.1], v. 29, n. 5, p. 1357-1367, 2015. 
GLAZIER, D.S. The fauna of North American temperate cold springs: patterns and hypotheses. Freshwater Biology, [s.1], v. 26, p. 527-542, 1991.

GOOGLE. 2017. Google Earth. Google, Inc.

GRAÇA, M.A.S.; POZO, J.; CANHOTO, C.; ELOSEG, A.L.S.; ORMEROD, S.J. Effects of Eucalyptus plantations on detritus, decomposers, and detritivores in streams. The Scientific World, Budapeste, n. 2, p. 1173-1185, 2002.

EMBRAPA - Empresa Brasileira de Pesquisa Agropecuária. Erosão, um indicador de impacto ambiental. Brasília, 2002, 43 p.

HARON, K.; BROOKES, P.C.; ANDERSON, J.M.; ZAKARIA, Z.Z. Dinâmica da biomassa microbiana e da matéria orgânica do solo em plantações de dendê ( Elaeis guineensis jacq.), Oeste da Malásia. Soil Biol. Biochem. [s.1], v. 30, n. 5, p. 547-552, 1998.

HERNANI, L.C. Sistemas de manejo de solo e perdas de nutrientes e matéria orgânica por erosão. Revista Brasileira de Ciência do Solo, Viçosa, v. 23, n. 1, p. 145-154, 1999.

ISLAM, K.R.; WEIL, R.R. Land use effects on soil quality in a tropical forest ecosystem of Banglasdesh. Agriculture, Ecosystems and Environmental., [s.1], v. 79, p. 9-19, 2000.

KRUPEK, R.A.; FELSKI, F. Avaliação da Cobertura Ripária de Rios e Riachos da Bacia Hidrográfica do Rio das Pedras, Região Centro-Sul do Estado do Paraná. Revista Ciências Exatas e Naturais, Guarapuava, v.8, n. 2, 2006.

LARRAÑAGA, A.; BASAGUREN, A.; ELOSEGI. A.; POZO, J. Impacts of Eucalyptus globules plantations on Atlantic streams: changes in invertebrate density and shredder traits. Fundamental and Applied Limnology/Archiv für Hydrobiologie, Stuttgart, v. 175, p. 151-160, 2009.

PINTO, R.; JUNIOR, J. S. Z.; ZANUNCIO, T.V.; ZANUNCIO, J. C.; LACERDA, M. C. Coleópteros coletados com armadilhas luminosas em plantios de Eucalyptus urophylla na região amazônica brasileira. Ciência Florestal, Santa Maria, v. 14, p. 111119, 2004.

PJF - Prefeitura de Juiz de Fora. Plano diretor de desenvolvimento urbano de Juiz de Fora. FUNALFA, Juiz de Fora, 2004.

R DEVELOPMENT CORE TEAM. R: a language and environment for statistical computing. R Foundation for Statistical Computing. 2013. Disponível em:

http://rproject.org

RASBAND, W.S. ImageJ. 2012. Disponível em:

https://imagej.nih.gov/ij/download.html. 
RESENDE, H. C.; MENDES, D. R.; MENDES, J. E. G.; BERNARDES, W. A. Diagnóstico e ações de conservação e recuperação para as nascentes do córrego-feio, Patrocínio, MG. Bioscience Journal, Uberlandia, v. 25, n. 5, p. 112-119, 2009.

SILVA, M. A.; SILVA, M. L.N.S.; CURI, N.; AVANZI, J.C.; LEITE, F.P.L. Sistemas de manejo em plantios florestais de eucalipto e perdas de solo e água na região do Vale do Rio Doce, MG. Ciência Florestal, Santa Maria, v. 21, n.4, p.765-776, 2011.

SUGANUMA, M. S.; TOREZAN, J. M. D.; CAVALHEIRO, A. L.; VANZELA, A. L. L.; BENATO, T. Comparando metodologias para avaliar a cobertura do dossel e a luminosidade no sub-bosque de um reflorestamento e uma floresta madura. Revista Árvore, v.32, p.377-385, 2008.

WANTZEN, K. M.; SIQUEIRA, A.; CUNHA, C. N.; SÁ, M.F. Stream valley systems of the Brazilian Cerrado: impact assessment and conservation scheme. Aquatic

Conservation: Marine and Freshwater Ecosystems, [s.1], v. 16, n. 7, p. 713-732, 2006.

WARD, J.V. Aquatic insect ecology: biology and habitat. New York, 1992, 438 p.

WILLIAMS, D. D.; WILLIAMS, N. E.; CAO, Y. Spatial differences in macroinvertebrate community structure in springs in southeastern Ontario in relation to their chemical and physical environments. Canadian Journal of Zoology, Ottawa, v.75, p.1404-1414, 1997. 


\section{CAPÍtulo 2: EFEITO dAS PLANTAÇÕES DE EUCALIPTO SOBRE A ESTRUTURA TAXONÔMICA E FUNCIONAL DAS ASSEMBLEIAS DE INSETOS AQUÁTICOS EM NASCENTES NEOTROPICAIS}

\section{RESUMO}

As nascentes são ecossistemas importantes em termos de serviços ambientais e sua qualidade tem sido degradada por diversos usos da terra. Os insetos aquáticos são fortemente afetados por impactos antrópicos. Por esse motivo, pesquisadores utilizam a estrutura taxonômica e funcional das assembleias de Ephemeroptera, Plecoptera e Trichoptera (EPT) para a avaliação da qualidade ambiental de nascentes neotropicais em áreas cultivadas com eucalipto. Nesse sentido, testamos a hipótese de que a riqueza de táxons é menor em áreas de eucalipto, e a composição taxonômica e diversidade funcional são diferentes daquelas de áreas de floresta. Para verificar essa hipótese, utilizamos um amostrador de rede de mão para coletar o substrato de 20 nascentes no sudeste do Brasil. Nossos resultados mostraram que em áreas plantadas com eucalipto, as nascentes apresentaram menor riqueza de gêneros e uma composição taxonômica de EPT diferente em relação as nascentes em áreas florestais. Também descobrimos que a respiração e o tamanho do corpo foram às características funcionais mais influenciadas pelas variáveis abióticas em nascentes, tanto em áreas de eucalipto quanto de floresta. A redução da vegetação marginal e a homogeneização do dossel nas áreas de eucalipto reduziram a qualidade da matéria vegetal, alterando a composição do substrato e a qualidade da água dos mananciais dessas áreas.

Palavras-chave: Serviços ecossistêmicos; EPT; diversidade funcional; traços funcionais; bentos; usos da terra. 


\begin{abstract}
Springs are important ecosystems in terms of environmental services and their quality has been degraded by various land uses. Aquatic insects are strongly affected by anthropogenic impacts. For this reason, researchers, use the taxonomic and functional structure of the Ephemeroptera, Plecoptera, and Trichoptera (EPT) assemblages for the evaluation of environmental quality of Neotropical springs in areas cultivated with eucalyptus. In this respect, we tested the hypothesis that taxa richness is lower in eucalyptus areas, and the taxonomic composition and functional diversity are different from those of forest areas. In order to verify this hypothesis, we used a pond net sampler to collect the substrate of 20 springs in Southeastern Brazil. Our results showed that in areas planted with eucalyptus, springs showed less richness of genera and a different EPT taxonomical composition compared to springs in forest areas. We also found that respiration and body size were the functional traits most influenced by abiotic variables in springs both in eucalyptus and forest areas. The reduced marginal vegetation and homogenization of the canopy in eucalyptus areas reduced the quality of the plant matter, altering the substrate composition and water quality of springs in those areas.
\end{abstract}

Keywords: Ecosystem services; EPT; functional diversity; functional traits; benthic; land uses. 


\subsection{INTRODUÇÃO}

Habitats de nascente constituem uma porção bastante restrita dos ambientes de água doce globais, mas são de importância ecológica fundamental (CANTONATI et al., 2007), uma vez que servem como área de refúgio para a biota de riachos ou certos estágios de vida de insetos aquáticos (CANTONATI et al., 2012), e são sugeridos como hotspots da biodiversidade aquática (SCARSBROOK; BARQUÍN; GRAY, 2007). Além disso, as nascentes têm papéis ecossistêmicos importantes (CANTONATI; BERTUZZI; SPITALE, 2007), pois são precursoras de rios e lagos, irrigam florestas e fornecem água limpa para consumo humano e da vida selvagem. Nos últimos anos, a expansão agrícola tem sido um dos principais fatores da redução da qualidade da água em todo o mundo (ZALIDIS et al., 2002; SCANLON et al., 2007; FOSTER et al., 2011; OVERBECK et al., 2015). Portanto, a compreensão dos diferentes impactos ambientais sobre as nascentes permite uma melhor gestão e formulação de estratégias de conservação para esses recursos hídricos (BARQUÍN; SCARSBROOK, 2008).

Espécies introduzidas do gênero Eucalyptus compõem grande parte das áreas cultivadas no mundo, devido à sua capacidade adaptativa, rápido crescimento e à variada aplicabilidade da madeira (PINTO et al., 2004). O Brasil, devido ao seu clima e solo favoráveis e grande extensão territorial, é um dos principais produtores de eucalipto do mundo (VALVERDE et al., 2004). No entanto, apesar da importância econômica da silvicultura, sua expansão em regiões tropicais tende a aumentar a fragmentação da vegetação natural (BROCKERHOFF et al., 2013), levando a uma perda de biodiversidade aquática (LARRAÑAGA et al., 2009; CORDERO-RIVERA; ÁlVAREZ; ÁlVAREZ, 2017). De acordo com Larrañaga et al. (2009), os sistemas aquáticos em áreas de eucalipto estão sujeitos à redução qualitativa e quantitativa da matéria orgânica da vegetação natural, uma das principais causas da redução da riqueza e abundância de insetos aquáticos nessas áreas.

Em todo o mundo, a composição taxonômica e a distribuição de insetos aquáticos são amplamente utilizadas em pesquisas sobre a qualidade dos ecossistemas límnicos (TOWNSEND et al., 2004; CARLSON; JOHNSON; MCKIE, 2013; AMARAL et al., 2015). No entanto, a análise de características funcionais como alimentação, tamanho e forma corporal (DEDIEU et al., 2015), geram informações distintas das fornecidas pela estrutura taxonômica das assembleias de insetos aquáticos e fornece informações complementares que levam a um melhor entendimento dos 
possíveis efeitos de áreas cultivadas sobre a fauna aquática. Nesse sentido, as mudanças no uso da terra atuam como filtros ambientais, selecionando características específicas que podem persistir sob determinadas condições (RIBERA et al., 2001). Akamagwuna et al. (2019) descobriram que natação e tamanho corporal pequeno eram características dominantes de insetos em riachos perturbados, enquanto o comportamento de rastejamento e corpo grande eram características dominantes em ambientes menos perturbados. Além disso, espera-se que a variação das características funcionais preveja não apenas os padrões estruturais da comunidade, mas também os processos que operam dentro desses ecossistemas (MAYFIELD et al., 2010).

A diversidade funcional descreve a estrutura funcional da comunidade (TERESA; CASATTI, 2012), quantificando o tipo e a variação das características funcionais que afetam o desempenho das espécies (TILMAN et al., 1997; DIAZ; CABIDO, 2001). Isso ocorre porque as diferentes características das espécies refletem as diferentes relações funcionais entre a fauna e o meio ambiente (TILMAN et al., 1997; DOLEDEC; PHILLIPS; TOWNSEND, 2011). Tilman et al. (1997), por exemplo, verificaram que a diversidade funcional foi a métrica que melhor explicou a produtividade das plantas em pastagens. Colzani et al. (2013) observaram que a modificação da paisagem alterou a organização funcional dos insetos em riachos de uma área de fragmento de Mata Atlântica. Zhang et al. (2019) descobriram que o enriquecimento de nutrientes em lagos na China homogeneizou a diversidade, tanto taxonômica quanto funcional, de macroinvertebrados aquáticos. Assim, modificações de habitat que alteram a estrutura taxonômica e funcional (FOSTER et al., 2011) terão forte influência nos processos ecossistêmicos e devem ser consideradas simultaneamente em estudos de impactos ambientais (ZHANG et al., 2019).

Imaturos de Ephemeroptera, Plecoptera e Trichoptera (EPT) estão frequentemente presentes em habitats de nascentes (STAUDACHER; FÜREDER, 2007; MAIOLINI; CAROLLI; SILVERI, 2011; SAVIĆ; DMITROVIĆ; PEŠIĆ, 2017), e devido à sua sensibilidade a mudanças ambientais em ambientes aquáticos, sua estrutura taxonômica e funcional são comumente usadas como indicadores ecológicos (DEDIEU et al., 2015; ANDRADE et al., 2017; DE CASTRO; DOLÉDEC; CALLISTO, 2017). Por exemplo, o estudo de gêneros EPT em riachos realizado por De Castro; Dolédec; Callisto (2017) mostrou que as composições taxonômicas e funcionais foram afetadas pelo uso do solo. Uma correlação foi encontrada por Akamagwuna et al. (2019), que observaram que a quantidade de sedimentos finos entrando em corpos 
d'água menos preservados favorece um conjunto específico de características funcionais de EPT, como tamanho corporal e modo de alimentação. Portanto, pode-se esperar que a variação das características taxonômicas e funcionais nas assembleias de EPT possam refletir mudanças nas condições ambientais da nascente.

Neste estudo, investigamos o efeito de áreas cultivadas com eucalipto na estrutura taxonômica e funcional de Ephemeroptera, Plecoptera e Trichoptera em habitats de nascentes Neotropicais. Procuramos também responder a duas questões complementares: (1) A estrutura taxonômica e a diversidade funcional diferem entre nascentes em áreas de eucalipto e florestas naturais? (2) Quais variáveis ambientais estão mais fortemente relacionadas às características funcionais de EPT de nascentes em áreas de eucalipto e floresta? Prevíamos que em áreas cultivadas com eucalipto, a riqueza dos táxons seria menor e a composição taxonômica e a diversidade funcional seriam diferentes quando comparadas às áreas de floresta natural, uma vez que a silvicultura tende a ser um fator de estresse que pode alterar a qualidade da água nas nascentes e reduzir a heterogeneidade ambiental e a qualidade dos recursos alimentares para a entomofauna.

\subsection{MATERIAL E MÉTODOS}

\subsection{1 Área de Estudo}

Para este estudo, foram selecionadas quatro áreas no estado de Minas Gerais, Sudeste do Brasil, onde o cultivo de eucalipto (Eucalyptus urograndis) é predominante (Figura 7). Em todas essas áreas, o eucalipto havia sido plantado há mais de dez anos. As áreas (A, B, C e D) estão localizadas dentro de um fragmento de Mata Atlântica na bacia do rio Paraíba do Sul. A vegetação predominante da região é classificada como Floresta Estacional Semidecidual Montana (SATO, 1995). O clima é classificado como Cwb de acordo com o sistema Köppen (PEEL; FINLAYSON; MCMAHON, 2007), ou seja, clima tropical de altitude, com precipitação concentrada entre outubro e abril, e a estação seca entre maio e setembro (PJF, 1996). A precipitação anual é de aproximadamente $1.500 \mathrm{~mm}$ e a temperatura média anual está em torno de $19^{\circ} \mathrm{C}(\mathrm{PJF}$, 2001).

A Área A $\left(21^{\circ} 37^{\prime} 33,12\right.$ "S e $43^{\circ} 16^{\prime} 53,67^{\prime}$ O), localizada no município de Coronel Pacheco, está inserida na sub-bacia do Rio Novo. A área total da propriedade é 
de 382.000 hectares, destes, cerca de 89.000 são utilizados para monocultura de eucalipto, 84.000 ha são plantados com eucalipto em sistema silvipastoril e outros 84.000 ha permanecem como floresta natural. Em relação às distâncias, a área A está a $30 \mathrm{~km}$ da área $\mathrm{B}, 43 \mathrm{~km}$ da área $\mathrm{C}$ e $45 \mathrm{~km}$ da área $\mathrm{D}$.

A Área B (2139'40,125 "S e 4334'30,05" O), localizada na zona rural da cidade de Juiz de Fora, está inserida na sub-bacia do rio Paraibuna, um dos principais afluentes do Paraíba do Sul Rio. A área total da propriedade é de 271.000 ha, sendo 75.000 ha de monocultura de eucalipto, 21.000 ha de eucalipto em sistema silvipastoril e outros 110.000 ha de floresta natural. Em relação às distâncias, a área $\mathrm{B}$ fica a $23 \mathrm{~km}$ da área $\mathrm{C}$ e a $24 \mathrm{~km}$ da área D.

A área C $\left(21^{\circ} 53^{\prime} 38,4\right.$ "S e 43\%36'47,9” O), com 147.000 ha, e a área D $\left(21^{\circ} 52^{\prime} 57,5^{\prime \prime S}\right.$ e 4336'13,5" O), com 62.000 ha, estão localizadas na área rural da cidade Juiz de Fora, e estão dentro da sub-bacia do Rio do Peixe, outro importante afluente do Rio Paraíba do Sul. Ambas as propriedades são destinadas apenas ao cultivo de eucalipto e estão localizadas a $2 \mathrm{~km}$ uma da outra. Na área C, cerca de 90.000 ha são cultivados com eucalipto e outros 57.000 ha de floresta natural. $\mathrm{Na}$ área $\mathrm{D}$, o eucalipto ocupa cerca de 46.000 ha e os outros 16.000 ha são de floresta natural. 
Figura 7 - Mapa do Brasil mostrando o estado de Minas Gerais e destacando a localização das propriedades A, B, C e D e nascentes (A1, A2, A3, A4, A5, A6 e A7), (B1, B2, B3, B4, B5, B6, B7 e B8), (C1, C2, C3 e C4) e (D1), distribuídos em áreas de eucalipto e floresta.

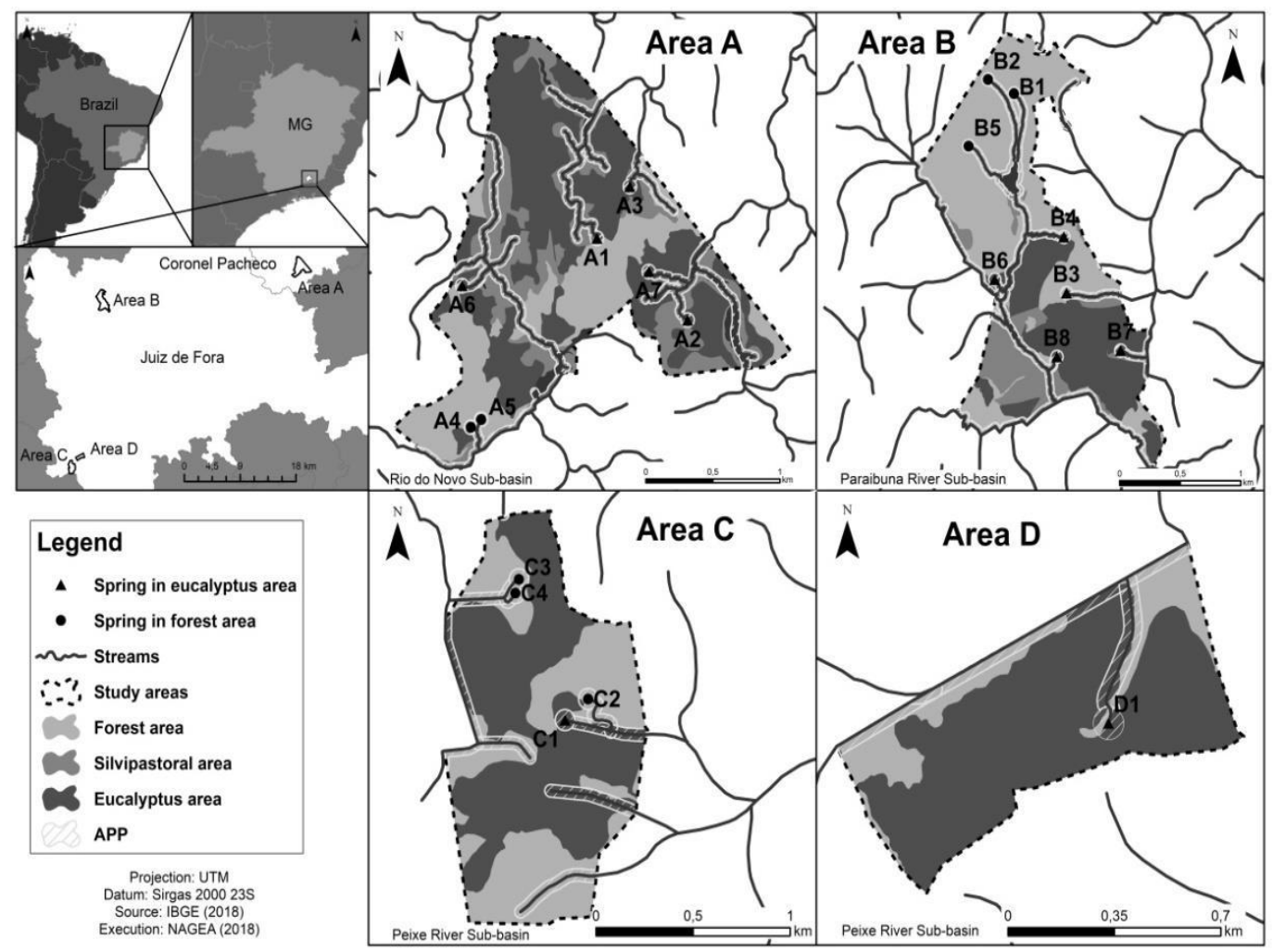

Fonte: Autores (2021).

\subsubsection{Coleta e identificação de fauna}

Um total de 20 nascentes perenes (largura média $=0,75 \pm 0,66 \mathrm{~m}$, profundidade média $=0,07 \pm 0,05 \mathrm{~m}$ ) foi amostrado apenas uma vez em julho, agosto e setembro de 2017, durante a estação seca. Dentre as nascentes, 12 estão localizadas em áreas de cultivo de eucalipto e oito estão em áreas florestais, protegidas pela Lei Federal 12.651/2012 (BRASIL, 2012).

Para cada nascente, um transecto de 5 metros foi estabelecido a partir da fonte de exfiltração, e três subamostras foram coletadas, compostas dos substratos principais (pedra, areia e folhiço), usando amostrador de rede de mão (área de $0,01 \mathrm{~m}^{2}$ e malha de $250 \mu \mathrm{m})$ especificamente projetada para coleta em nascentes, que possuem tamanho reduzido (LENCIONI; MARZIALI; ROSSARO, 2012). Para cada ponto de amostragem, foi realizado um arrasto longitudinal da jusante para a montante em zigue- 
zague por 15 segundos, para evitar viés na seleção de habitats (HUGHES; PECK, 2008), totalizando 45 segundos por nascente. As amostras de substrato para análise da fauna foram preservadas individualmente em álcool $85 \%$ e levadas ao laboratório. Para este estudo, cada nascente foi considerada uma unidade amostral. Em cada nascente, uma segunda amostra do substrato foi coletada para análise de granulometria e matéria orgânica.

Os espécimes de EPT coletados foram identificados em nível de gênero sob microscópio estereoscópico, com exceção de ninfas de Baetidae (Ephemeroptera), que foram montadas em lâminas e identificadas em microscópio óptico. As seguintes chaves foram utilizadas para a identificação: Bouchard (2004) e Salles (2006) para Ephemeroptera; Olifiers et al. (2004) para Plecoptera; e Pes (2005), Pes; Hamada; Nessimian (2005) e Calor; Froehlich (2008) para Trichoptera. Posteriormente, os espécimes foram colocados em frascos de vidro contendo álcool $75 \%$ e mantidos no Laboratório de Invertebrados Bentônicos (LIB) da Universidade Federal de Juiz de Fora, Minas Gerais.

\subsubsection{Variáveis Ambientais}

As coordenadas geográficas e a altitude de cada nascente foram obtidas via GPS - modelo Garmin MAP 76CSx. Avaliamos o uso da terra e a cobertura vegetal para cada área com base em imagens de satélite de alta resolução (resolução espacial de 0,5-5 m, dados do Google Earth, GOOGLE, 2017) em um grupo de imagens multiespectrais Landsat (combinação de cores falsas RGB). Além disso, usamos o mapa gerado para descrever a contribuição das Áreas de Preservação Permanente (APP) ao redor de cada nascente, calculando a proporção de vegetação natural dentro de cada "buffer". Cada "buffer" foi delimitada como uma área circular (raio de $50 \mathrm{~m}$ ), de acordo com a Lei Federal 12.651 / 2012 (BRASIL, 2012) (Tabela 3).

A porcentagem de cobertura vegetal de cada nascente foi avaliada por meio de fotografia digital, segundo Suganuma et al. (2008). As imagens foram convertidas para preto e branco e analisadas pelo software livre ImageJ (RASBAND, 2015). O resultado obtido foi um valor médio em pixels, que variou de zero (ausência de área branca) a 255 pixels (entrada total de luminosidade). Os valores obtidos foram convertidos em porcentagem. 
Tabela 3 - Área, uso da terra, altitude e Área de Preservação Permanente (APP) das 20 nascentes estudadas na bacia hidrográfica do Rio Paraíba do Sul, Sudeste do Brasil.

\begin{tabular}{cccc}
\hline Área & Uso da terra & Altitude $(\mathbf{m})$ & APP Nascente (\%) \\
\hline A1 & Eucalipto & 696 & 23 \\
A2 & Eucalipto & 753 & 0 \\
A3 & Eucalipto & 638 & 3 \\
A4 & Floresta & 751 & 100 \\
A5 & Floresta & 781 & 100 \\
A6 & Eucalipto & 666 & 44 \\
A7 & Eucalipto & 770 & 67 \\
B1 & Floresta & 774 & 100 \\
B2 & Floresta & 777 & 100 \\
B3 & Eucalipto & 762 & 51 \\
B4 & Eucalipto & 765 & 31 \\
B5 & Floresta & 791 & 100 \\
B6 & Eucalipto & 745 & 6 \\
B7 & Eucalipto & 740 & 6 \\
B8 & Eucalipto & 754 & 19 \\
C1 & Eucalipto & 860 & 3 \\
C2 & Floresta & 890 & 91 \\
C3 & Floresta & 863 & 100 \\
C4 & Floresta & 866 & 100 \\
D1 & Eucalipto & 861 & 23 \\
\hline
\end{tabular}

Fonte: Elaborado pelos autores (2021).

As variáveis temperatura $\left({ }^{\circ} \mathrm{C}\right)$, condutividade $(\mu \mathrm{S} / \mathrm{cm})$, turbidez (NTU) e oxigênio dissolvido $(\mathrm{mg} / \mathrm{L})$ foram medidas na zona de exfiltração de cada nascente por meio de uma sonda multiparâmetros (Pro DSS/YSY). A profundidade e a largura foram obtidas com trena métrica. Além disso, na zona de exfiltração, amostras de água foram coletadas em frascos de polipropileno $(500 \mathrm{ml})$ para determinar as concentrações de nitrogênio total (STRICKLAND; PARSONS, 1968) e fósforo total (WETZEL; GENE, 2001).

Para a caracterização granulométrica, cada amostra de substrato foi seca em temperatura ambiente e $120 \mathrm{~g}$ foram separados e peneirados sob agitador mecânico (SOLOTEST), por um tempo padronizado de 30 minutos e 3 de frequência, com um conjunto de peneiras de teste analítico ( $2 \mathrm{~mm}$ a 75 malha $\mu \mathrm{m})$ e classificados em cinco frações: areia muito grossa $(1 \mathrm{~mm}<\mathrm{x}<2 \mathrm{~mm})$, areia grossa $(500 \mu \mathrm{m}<\mathrm{x}<1 \mathrm{~mm})$, areia média $(250 \mu \mathrm{m}<\mathrm{x}<500 \mu \mathrm{m})$, areia fina $(150 \mu \mathrm{m}<\mathrm{x}<250 \mu \mathrm{m})$, areia ultrafina $(75 \mu \mathrm{m}$ $<\mathrm{x}<150 \mu \mathrm{m})$ e silte / argila $(<75 \mu \mathrm{m})$, conforme procedimento recomendado pela 
norma técnica ABNT NBR 7181 (ABNT, 1984). O sedimento de cada fração de tamanho foi pesado em balança de precisão (SHIMADZU AUY220) com precisão de \pm 0,001 g. Parte do sedimento coletado (3g) de cada amostra foi separada para determinação do teor de matéria orgânica de acordo com a norma técnica ABNT NBR 13600 (ABNT, 1996).

\subsubsection{Traços funcionais}

Para caracterizar os traços funcionais, foram utilizados quatro tipos de categorias (ecologia, história de vida, mobilidade e morfologia), distribuídos em seis traços funcionais (Tabela 4). Essas características funcionais foram escolhidas com base na literatura sobre diversidade funcional de insetos (BÊCHE; STATZNER 2009; DEDIEU et al., 2015; ANDRADE et al. 2017; DE CASTRO; DOLÉDEC; CALLISTO, 2017), conforme indicado por Poff et al. (2006). Os traços usados envolveram aspectos dos gêneros de EPT para refletir a integridade ambiental das nascentes. O hábito alimentar, por exemplo, está intimamente relacionado ao tipo de recurso (PETCHEY; GASTON 2006) e é importante para entender o funcionamento dos ecossistemas aquáticos (STERNER, 2009). Por outro lado, as características da história de vida, como voltismo, ditarão o quão rápido os organismos crescem e se reproduzem, sendo associada sobrevivência e recuperação a eventos de perturbação (Williams et al., 2010). Os dados usados para a categorização das características funcionais foram obtidos de estudos anteriores de insetos aquáticos (BAPTISTA et al., 2006; POFF et al. 2006; TOMANOVA; USSEGLIO-POLATERA, 2007; TOMANOVA; MOYA; OBERDORFF, 2008; DEDIEU et al., 2015; PILIÉRE et al., 2015). Para medir o tamanho corporal de cada gênero EPT, foi medido o comprimento da cabeça até o final do abdômen (plano corporal) de 10\% de todos os indivíduos amostrados (DE CASTRO; DOLÉDEC; CALLISTO, 2017), para classificação em quatro categorias de tamanho (Tabela 4) de acordo com sua distribuição em um histograma. 
Tabela 4 - Características funcionais e códigos utilizados para os 17 gêneros de Ephemeroptera, Plecoptera e Trichoptera coletados nas 20 nascentes estudadas na bacia hidrográfica do Rio Paraíba do Sul, Sudeste do Brasil.

\begin{tabular}{|c|c|c|c|}
\hline Tipo & $\begin{array}{l}\text { Traços } \\
\text { Funcionais }\end{array}$ & Categorias & Código \\
\hline \multirow{5}{*}{ 1. Ecologia } & \multirow{5}{*}{$\begin{array}{l}\text { Modo de } \\
\text { alimentação }\end{array}$} & Coletor & Co \\
\hline & & Filtrador & $\mathrm{Fi}$ \\
\hline & & Raspador & $\mathrm{Sc}$ \\
\hline & & Predador & $\operatorname{Pr}$ \\
\hline & & Fragmentador & $\mathrm{Sh}$ \\
\hline \multirow{5}{*}{$\begin{array}{l}\text { 2. História de } \\
\text { Vida }\end{array}$} & \multirow{3}{*}{ Voltismo } & Semivoltismo ( $<1$ geração por ano) & $\mathrm{Se}$ \\
\hline & & Univoltismo (1 geração por ano) & Um \\
\hline & & Bi- ou multivoltismo ( $>1$ geração por ano) & $\mathrm{Bi}$ \\
\hline & \multirow{2}{*}{ Respiração } & Cutânea & Sk \\
\hline & & Branquial & $\mathrm{Br}$ \\
\hline \multirow{5}{*}{ 3. Mobilidade } & \multirow{5}{*}{ Locomoção/Habitat } & Escavador & $\mathrm{Di}$ \\
\hline & & Escalador & $\mathrm{Ca}$ \\
\hline & & Rastejante & $\mathrm{Cr}$ \\
\hline & & Agarrador & Gr \\
\hline & & Nadador & Sw \\
\hline \multirow{6}{*}{ 4. Morfologia } & \multirow{2}{*}{ Forma do corpo } & Plano & Bo \\
\hline & & Cilíndrico & $\mathrm{Cy}$ \\
\hline & \multirow{4}{*}{ Tamanho do corpo } & $0,2-0,4 \mathrm{~cm}$ & Cla1 \\
\hline & & $0,4-0,6 \mathrm{~cm}$ & Cla2 \\
\hline & & $0,6-0,8 \mathrm{~cm}$ & Cla3 \\
\hline & & $>0,8 \mathrm{~cm}$ & $\mathrm{Cla} 4$ \\
\hline
\end{tabular}

Fonte: Elaborada pelos autores (2021).

\subsubsection{Métricas de diversidade funcional}

A diversidade funcional (DF) foi avaliada aplicando três índices complementares de riqueza funcional, uniformidade funcional (VILLÉGER; MASON; MOUILLOT, 2008) e dispersão funcional (LALIBERTÉ; LEGENDRE 2010), que medem diferentes aspectos das espécies no espaço funcional. A riqueza funcional (FRic) corresponde ao volume do espaço funcional (volume do casco convexo) preenchido com as espécies de uma comunidade (VILLÉGER; MASON; MOUILLOT, 2008). Uniformidade funcional (FEve) é uma medida da regularidade com a qual o espaço funcional é ocupado pela espécie, ponderada pela distribuição da abundância (VILLÉGER; MASON; MOUILLOT, 2008). A dispersão funcional (FDis), proposta por Laliberté e Legendre (2010), foi incorporada como uma medida de diversidade funcional. Segundo os 
autores, esse índice envolve a distância média de cada espécie em um espaço de características funcionais do centroide de todas as espécies da comunidade, ponderada pela abundância relativa. Os índices escolhidos são independentes e medem diferentes aspectos da diversidade funcional, portanto, é necessária uma análise conjunta dos três componentes (SCHLEUTER et al., 2010).

Para obter os três índices de diversidade funcional, usamos a função dbFD do software R (R DEVELOPMENT CORE TEAM, 2016) do pacote FD (LALIBERTÉ; LEGENDRE, 2010). Para os cálculos, foi obtida uma matriz de distâncias com os dados das características funcionais, utilizando a distância de Gower (GOWER, 1966), da qual extraímos via PCoA os dois primeiros eixos, usados junto com a matriz de abundância de táxons para estimar os índices de diversidade funcional (SCHLEUTER et al., 2010).

\subsubsection{Análise de dados}

As análises foram realizadas com o software $\mathrm{R}$ ( $\mathrm{R}$ DEVELOPMENT CORE TEAM, 2016), utilizando os pacotes vegan (OKSANEN et al. 2016), car (FOX; WEISBERG, 2019), stats (R DEVELOPMENT CORE TEAM, 2016) e indicspecies (DE CACERES; JANSEN, 2015).

Após a confirmação da normalidade e homogeneidade dos dados, alterações nas assembleias de EPT de nascentes em áreas de eucalipto e floresta foram avaliadas através do teste $\mathrm{t}$ de Student para determinar possíveis diferenças significativas na riqueza de gêneros, riqueza funcional (FRic), uniformidade funcional (FEve) e dispersão funcional (FDis). Uma vez que a abundância numérica diferiu entre as duas áreas (Tabela 4), a riqueza taxonômica padrão com rarefação também foi calculada (100 randomizações), com base na menor abundância (1005 organismos). Como esses dados não satisfaziam os critérios de normalidade e homogeneidade, empregamos o teste de Wilcoxon-Mann-Whitney para investigar possível variação da riqueza taxonômica padrão entre as duas áreas.

A análise de similaridade (ANOSIM) foi usada para verificar a similaridade na composição das assembleias de EPT entre nascentes em áreas de eucalipto e floresta. Os dados foram transformados em $\log (\log \mathrm{x}+1)$ e, em seguida, a matriz de distância BrayCurtis foi calculada usando a função vegdist. A análise foi realizada usando a função anosim do pacote vegan. A análise de espécies indicadoras (IndVal; DUFRENE; LEGENDRE, 1997) foi aplicada para identificar possível associação de taxa EPT com 
nascentes em áreas de eucalipto e/ou floresta. Esta análise foi realizada usando a função multipatt do pacote indicspecies.

A influência das variáveis ambientais nas características funcionais foi avaliada por meio da análise de redundância (RDA) (LEGENDRE; LEGENDRE, 1998). A matriz CWM (unidades amostrais x características), gerada a partir da abundância dos táxons (unidades amostrais $\mathrm{x}$ gêneros) e características funcionais (gêneros $\mathrm{x}$ características) (GIMENEZ; HIGUTI, 2017), foi utilizada com as variáveis ambientais transformadas pelo cálculo da RDA. A significância das frações de explicação oferecidas pela análise e os eixos foi avaliada por meio de testes de permutação, usando 999 randomizações. As nascentes nas áreas de eucalipto A1 e B8 não foram incluídas nesta análise devido à ausência de espécimes de EPT.

\subsection{RESULTADOS}

Coletamos um total de 2.961 imaturos de Ephemeroptera, Plecoptera e Trichoptera, distribuídos em 17 gêneros e 11 famílias (Tabela 5). Tanto os gêneros observados quanto aqueles padronizados pela riqueza rarefeita foram maiores em nascentes em áreas de floresta do que em áreas de eucalipto $(\mathrm{t}=-2,399, \mathrm{gl}=13, \mathrm{p}=0,031$ e $\mathrm{W}=2741,5$, valor de $\mathrm{p}<0,05$ respectivamente). Por outro lado, riqueza funcional $(\mathrm{t}=\mathrm{-}$ $1,124, \mathrm{gl}=13, \mathrm{p}=0,281)$, uniformidade funcional $(\mathrm{t}=0,799, \mathrm{gl}=13, \mathrm{p}=0,438) \mathrm{e}$ dispersão funcional $(\mathrm{t}=0,038, \mathrm{gl}=13, \mathrm{p}=0,969)$ não variaram significativamente entre as nascentes das áreas estudadas (Figura 8). 
Tabela 5 - Abundância de Ephemeroptera, Plecoptera e Trichoptera coletada em 12 nascentes em áreas de eucalipto e 8 em áreas de floresta na bacia hidrográfica do rio Paraíba do Sul, sudeste do Brasil.

\begin{tabular}{|c|c|c|c|}
\hline & \multicolumn{2}{|c|}{ Abundância } \\
\hline & & Eucalipto & Floresta \\
\hline \multicolumn{4}{|c|}{ Ephemeroptera } \\
\hline \multicolumn{4}{|l|}{ Baetidae } \\
\hline & Tupiara & 3 & 0 \\
\hline & Zelusia & 15 & 6 \\
\hline
\end{tabular}

Caenidae

$\begin{array}{lll}\text { Caenis } & 0 & 2\end{array}$

Leptophlebiidae

$\begin{array}{rcc}\text { Askola } & 74 & 102 \\ \text { Massartella } & 0 & 25\end{array}$

Plecoptera

Perlidae

Macrogynoplax $\quad 10 \quad 9$

Trichoptera

Calamoceratidae

Helicopsychidae

Phylloicus $\quad 143 \quad 357$

Helicopsyche $\quad 365 \quad 151$

Hydropsychidae

$\begin{array}{rlc}\text { Leptonema } & 0 & 24 \\ \text { Macronema } & 0 & 1 \\ \text { Macrostemum } & 0 & 12 \\ \text { Smicridea } & 0 & 42\end{array}$

Hydroptilidae

$\begin{array}{lll}\text { Oxyethira } & 5 & 0\end{array}$

Leptoceridae

$\begin{array}{rcc}\text { Oecetis } & 33 & 133 \\ \text { Triplectides } & 255 & 1092\end{array}$

Philopotamidae

Chimarra $\quad 4 \quad 0$

Polycentropodidae

\begin{tabular}{|c|c|c|}
\hline & 98 & 0 \\
\hline Total & 1005 & 1956 \\
\hline
\end{tabular}


Figura 8 - (A) Riqueza taxonômica, (B) riqueza estimada, (C) riqueza funcional, (D) equitabilidade funcional e (E) dispersão funcional de Ephemeroptera, Plecoptera e

Trichoptera em nascentes em áreas de eucalipto e áreas de floresta.
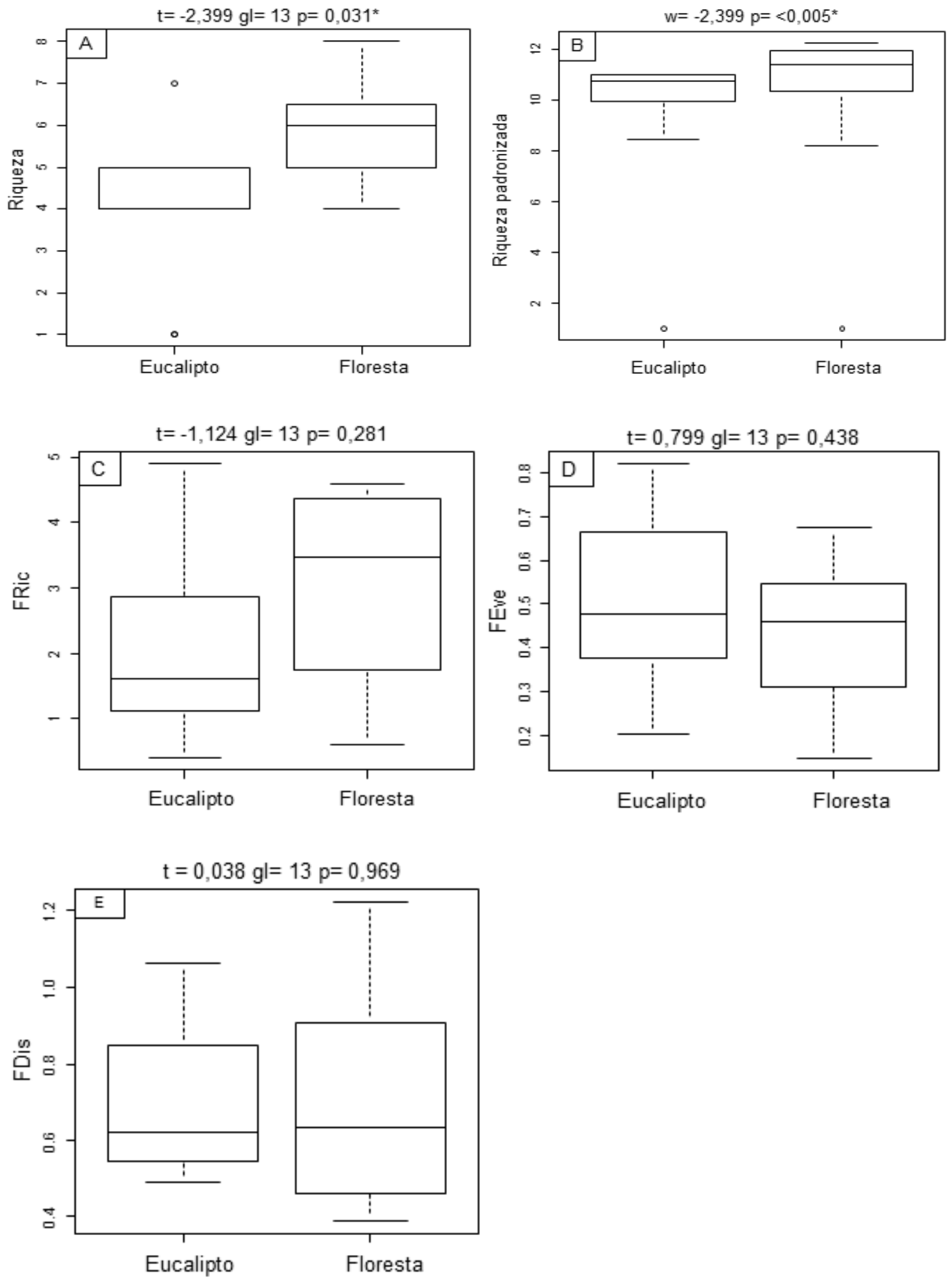

Fonte: Os autores (2021).

* Indica diferença significativa entre nascentes em áreas de eucalipto e floresta (teste $t$, $\mathrm{p} \leq 0,05)$. 
A análise de similaridade (ANOSIM) evidenciou diferença $(\mathrm{R}=0,194 ; \mathrm{p}=$ 0,002) na composição do EPT entre nascentes em áreas de eucalipto e de floresta. A análise das espécies indicadoras (IndVal) identificou três gêneros com maior abundância e frequência em áreas de floresta, mas nenhum gênero foi encontrado como indicador de áreas de eucalipto (Tabela 6).

Tabela 6 - Resultado da análise de espécies indicadoras (IndVal), para nascentes em áreas de eucalipto e floresta na bacia hidrográfica do rio Paraíba do Sul, Sudeste do Brasil.

\begin{tabular}{cccc}
\hline Gênero & Uso da terra & IndVal & $p$-valor \\
\hline Triplectides & Floresta & 0.918 & 0.01 \\
Massartella & Floresta & 0.791 & 0.01 \\
Smicridea & Floresta & 0.707 & 0.03 \\
\hline
\end{tabular}

Fonte: Elaborada pelos autores (2021).

Os dois primeiros eixos da análise de redundância (RDA) utilizados para interpretar os resultados foram significativos $(p=0,04)$ e explicaram $75,4 \%$ da distribuição das características funcionais no gradiente ambiental. As variáveis ambientais que mais influenciaram as características funcionais de EPT em áreas florestais foram oxigênio dissolvido (Oxy) e areia muito grossa (Vs). Por outro lado, condutividade (Cond), turbidez (Turb), nitrogênio total (NT), areia grossa (Cs), areia muito fina (Uf) e silte e argila (Sc) foram as variáveis ambientais que mais influenciaram as características de EPT em áreas de eucalipto. A matéria orgânica $(\mathrm{Om})$, a cobertura vegetal $(\mathrm{Vc})$ e a temperatura $\left(\mathrm{T}^{\circ}\right)$ estiveram associadas às nascentes de ambas as áreas. Apesar da posição intermediária de parte das características funcionais, os traços respiração cutânea (Sk) e tamanho classe 2 (Cla2) foram associados a nascentes em áreas florestadas, enquanto os traços respiração branquial (Br) e tamanho classe 3 (Cla3) foram associados com nascentes em áreas de eucalipto (Figura 9). 
Figura 9 - Análise de Redundância (RDA) considerando as variáveis ambientais e as categorias de características funcionais de Ephemeroptera, Plecoptera e Trichoptera em nascentes em áreas de eucalipto e de floresta.

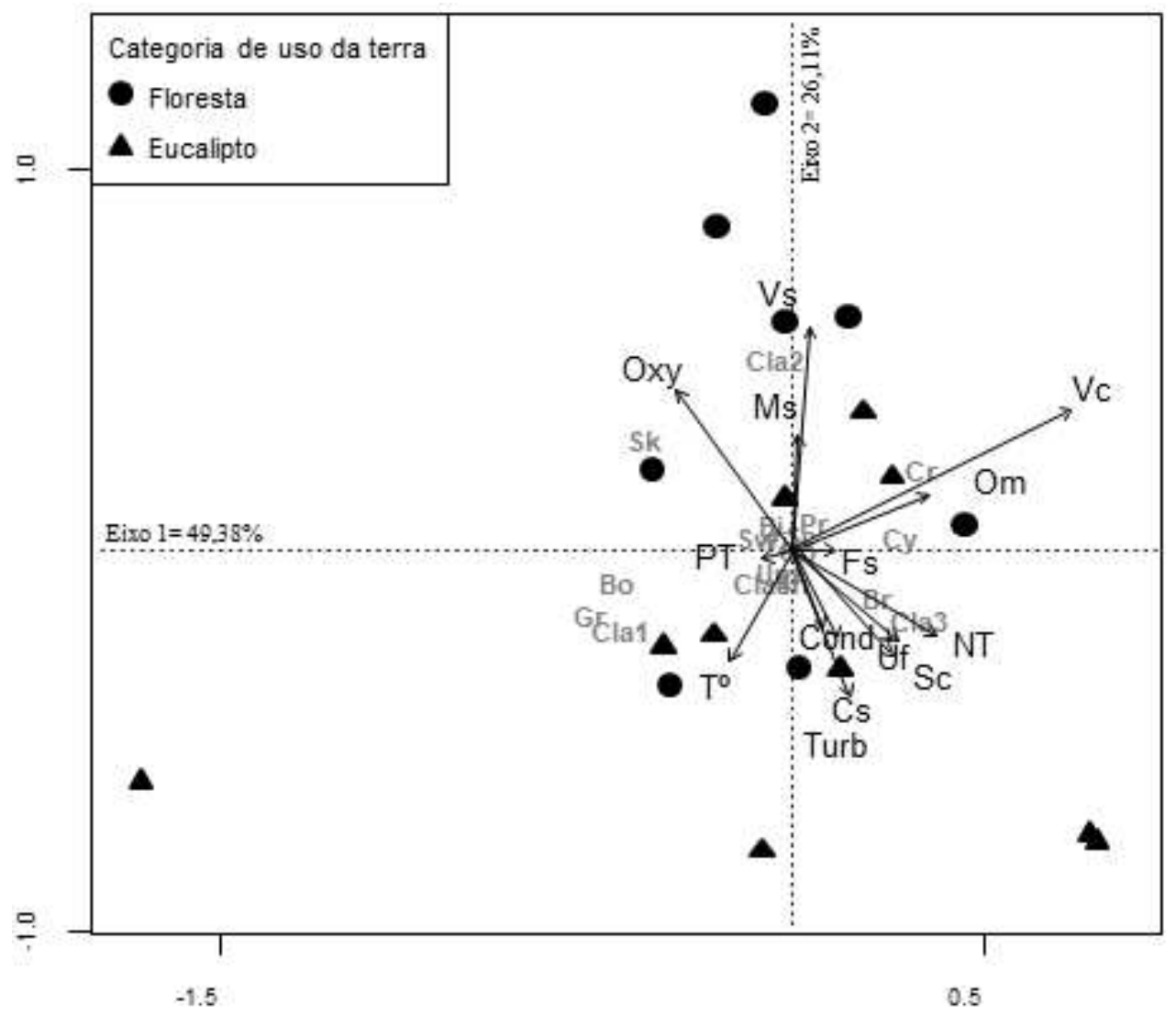

Fonte: Os autores (2021).

Em que: $\mathrm{T}^{\mathrm{o}}$ : temperatura; Cond: condutividade; Oxy: oxigênio; Turb: turbidez; Vc: cobertura vegetal; PT: fósforo total; NT: nitrogênio total; Vs: areia muito grossa; Cs: areia grossa; Ms: areia média; Fs: areia fina; Uf: areia ultrafina; Sc: silte/argila; Om: matéria orgânica. Os códigos para as categorias das características funcionais de EPT são mostrados na Tabela 4.

\subsection{DISCUSSÃO}

\subsubsection{Estrutura Taxonômica e Funcional}

Estudos ambientais sobre nascentes são importantes para o entendimento e gestão das questões associadas ao uso da terra, uma vez que uma queda constante na qualidade da água tem sido observada em todo o mundo (FERREIRA et al., 2011). Os resultados deste estudo corroboram a hipótese de que o cultivo de eucalipto altera a 
estrutura taxonômica da fauna de EPT de nascente. Em áreas de eucalipto, as nascentes apresentaram menor riqueza de gêneros e uma composição taxonômica de EPT diferente em comparação com as nascentes em áreas de floresta. Em relação a esses aspectos, resultados semelhantes foram encontrados por Andrade et al. (2017), que apontaram para o declínio da riqueza dos gêneros EPT, bem como uma mudança na composição faunística de riachos localizados em áreas cultivadas com palma na Amazônia. A conversão de florestas naturais em grandes áreas cultivadas prejudica a conservação da biodiversidade (CUNHA; MONTANG; JUEN, 2015; DE CASTRO; DOLÉDEC; CALLISTO, 2017), embora o efeito nos sistemas aquáticos dependa diretamente de como essas áreas são ambientalmente manejadas (FITZHERBERT et al., 2008; FERREIRA et al., 2016; CORDERO-RIVERA; ÁLVAREZ; ÁLVAREZ, 2017).

Embora uma relação positiva possa ser esperada entre a diversidade taxonômica e funcional (VILLÉGER; MASON; MOUILLOT, 2008), nossos resultados mostraram que os índices de diversidade funcional usados não foram significativamente diferentes entre áreas de floresta e cultivadas com eucalipto e, portanto, não confirmaram esta parte da nossa hipótese inicial. Estudos anteriores mostraram uma relação positiva entre diversidade taxonômica e funcional (LONGHI; BEISNER, 2010; TERESA; CASATTI, 2012), enquanto outros estudos não encontraram esse padrão em peixes (CARVALHO; TEJERINA-GARRO, 2015) e em macroinvertebrados marinhos (WONG; DOWD, 2015). Os últimos autores concluíram que a estrutura funcional nem sempre reflete os padrões taxonômicos da comunidade. Assim, é possível concluir que a diminuição da riqueza de táxons de EPT em nascentes em áreas de eucalipto não alterou os índices de diversidade funcional deste estudo.

Esse resultado pode indicar que os táxons que compõem as assembleias de EPT de nascentes em áreas de floresta e eucalipto possuem características semelhantes. De acordo com Petchey; Gaston (2006), quanto mais espécies estiverem contidas em grupos funcionais, maior será a redundância de sua contribuição para a diversidade funcional e maior será a resistência da comunidade à variação ambiental. A razão é que as espécies que não são eliminadas preenchem o papel funcional das que não estão mais presentes na comunidade (ANDRADE et al., 2017). Vale ressaltar que as áreas cultivadas com eucalipto são abertas e homogêneas, mas quando associadas à mata ciliar fornecem aporte de matéria orgânica para as nascentes, criando condições favoráveis para hospedar assembleias de EPT com estrutura funcional semelhante às encontradas em áreas de floresta. 
A frequência e abundância do fragmentador Triplectides (Trichoptera), que neste estudo foi um indicador de nascente de área florestal, podem ter sido afetadas negativamente pela qualidade do substrato. Graça et al. (2002) constataram que a qualidade dos substratos vegetais de riachos em áreas de eucalipto em Portugal afetava diretamente a decomposição microbiana e, consequentemente, a alimentação de organismos fragmentadores, uma vez que as folhas do eucalipto apresentam alto teor de óleos e compostos polifenólicos. Esse resultado mostra que larvas de Triplectides podem ser menos tolerantes ao consumo de folhas de eucalipto nas nascentes. No entanto, outros organismos fragmentadores podem, pelo menos em parte, desempenhar esta função alimentar deixada em aberto pelo táxon, como Phylloicus e Oxyethira, este último, apesar de sua baixa representatividade numérica, não ocorreu em áreas de floresta. Quando as espécies coexistentes de uma assembleia e/ou comunidade apresentam características funcionais semelhantes, são consideradas comunidades redundantes (BIHN; GEBAUER; BRAND, 2010), e algumas espécies podem desaparecer localmente sem perda substancial para o funcionamento do ecossistema (LAWTON; BROWN, 1993). Também deve ser ressaltado que, a diferença comportamental entre as espécies que compartilham as mesmas características funcionais (por exemplo, hábito alimentar) é um elemento crucial na adaptação dos animais às mudanças ambientais (CORDERO-RIVERA; ÁLVAREZ; ÁLVAREZ, 2017) e, portanto, essencial para a manutenção dos ecossistemas.

\subsubsection{Variáveis Ambientais e Características Funcionais}

A influência da silvicultura do eucalipto e de áreas florestais nas características funcionais das assembleias de EPT de nascentes foi associada à condutividade, turbidez, nitrogênio total, areia grossa, areia muito fina, silte e argila. No entanto, espécies que compartilham características funcionais semelhantes podem mitigar a resposta do traço à variação ambiental (DE CASTRO; DOLÉDEC; CALLISTO, 2017), o que pode explicar a posição intermediária de parte dos traços funcionais de nascentes em áreas de eucalipto e de floresta na análise RDA. A RDA mostrou que a granulometria e diferentes variáveis físicas e químicas da água foram responsáveis pela maior parte da variação das características funcionais de EPT. Enquanto as nascentes em áreas de floresta foram associadas a uma composição mais grosseira do sedimento e maiores níveis de oxigênio, aquelas em áreas de eucalipto foram associadas à granulometria 
mais fina e maiores níveis de nitrogênio total, condutividade e turbidez da água. Esses resultados indicam que o uso do solo afetou a ocorrência dos traços funcionais tamanhos corporais e respiração entre as áreas estudadas.

O bom estado de conservação da vegetação natural no entorno das nascentes em áreas de floresta pode ter influenciado o predomínio de sedimentos mais grossos, bem como a maior oxigenação da água. Essas variáveis influenciaram diretamente na distribuição de imaturos de EPT de menor porte, bem como na respiração cutânea. Os organismos aquáticos com respiração cutânea possuem uma cutícula altamente permeável (ALBERTONI; PALMA-SILVA, 2010), o que aumenta sua eficiência respiratória. Mas os insetos aquáticos com cutícula mais permeável estão mais expostos a diferentes estressores abióticos presentes na água (BUCHWALTER; JENKINS; CURTIS, 2002), por isso são encontrados preferencialmente em locais mais conservados (HARE, 1992). Portanto, a maioria dos insetos aquáticos com respiração cutânea está limitada a água bem oxigenada (BUCHWALTER; JENKINS; CURTIS, 2002; ALBERTONI; PALMA-SILVA, 2010), o que foi observado em nossos resultados.

Embora a RDA tenha mostrado que a cobertura vegetal estava associada a ambas as áreas, as imagens de satélite de alta resolução mostraram que as nascentes em áreas de eucalipto tinham menos ou nenhuma vegetação ciliar. A vegetação ciliar é de fundamental importância para a manutenção da qualidade da água, pois atua como uma zona tampão entre o curso d'água e as áreas adjacentes cultivadas, retendo grande parte dos sedimentos, pesticidas e nutrientes (BOTELHO; DAVIDE, 2002), que de outra forma seriam lixiviados para a água da nascente. A presença de sedimentos de menor fração granulométrica é indicativa de redução da mata ciliar (BRITO et al., 2009) e erosão das margens, podendo alterar a qualidade da água (FRANÇA; MORENO; CALLISTO, 2006; BRYCE; LOMNICKY; KAUFMANN, 2010; DE CASTRO; DOLÉDEC; CALLISTO, 2017) e têm um forte efeito na fauna bentônica (WOOD; ARMITAGE, 1997). Alguns estudos têm mostrado que a dimensão dos sedimentos presentes nos corpos d'água favorece um determinado tamanho corporal da comunidade de macroinvertebrados aquáticos (LAMOUROUX; DOLÉDEC; GAYRAUD, 2004; BEAUGER et al., 2006). Segundo esses autores, invertebrados com menor tamanho corporal são mais comuns em substratos relativamente grosseiros, pois utilizam os pequenos interstícios dos sedimentos como proteção. Sedimentos com maior granulometria podem servir como abrigo contra predadores (BEAUGER et al., 2006). 
Assim, as mudanças ambientais decorrentes da silvicultura do eucalipto favorecem a ocorrência de determinados tamanhos corporais e características respiratórias nas assembleias de EPT de nascente.

\subsection{CONCLUSÃO}

Nossos resultados mostram que apesar da similaridade dos índices de diversidade funcional de EPT em nascentes de áreas cultivadas e florestais, a composição faunística e a riqueza taxonômica de Ephemeroptera, Plecoptera e Trichoptera foram afetadas pelas plantações de eucalipto. A homogeneização e redução da vegetação marginal nessas áreas prejudicam os mecanismos naturais de retenção de sedimentos, alteram a qualidade da água e da matéria vegetal que entra nas nascentes, afetando a fauna bentônica. A diferença encontrada no tipo de respiração e tamanho corporal das assembleias de EPT em nascentes de área de floresta e de eucalipto indica que alterações nas variáveis granulométricas e físicas e químicas da água selecionaram um determinado grupo de características funcionais dos insetos aquáticos nessas áreas. Este perfil de característica encontrado em nosso estudo pode contribuir para estudos futuros das características funcionais de EPT em áreas de silvicultura, uma vez que o uso para biomonitoramento de nascentes neotropicais ainda é pouco conhecido. Da mesma forma, estudos futuros devem investigar a resposta de outros grupos taxonômicos, para análise comparativa do uso do solo sobre as características funcionais de insetos aquáticos. Portanto, os resultados deste estudo sugerem a importância de se considerar à estrutura taxonômica e funcional dos insetos aquáticos na avaliação ambiental de nascentes neotropicais, a fim de melhor compreender a influência do uso do solo na estrutura e funcionamento desses ecossistemas. 


\section{REFERÊNCIAS}

ABNT- Associação Brasileira de Normas Técnicas. NBR 7181: Solo - análise granulométrica. Rio de Janeiro/RJ, 1984.

ABNT- Associação Brasileira de Normas Técnicas. NBR 13600: Solo - Determinação do teor de matéria orgânica por queima a $440^{\circ} \mathrm{C}$. Rio de Janeiro/RJ, 1996.

AKAMAGWUNA, F. C.; MENSAH, P. K.; NNADOZIE, C. F.; ODUME, O. N. Traitbased responses of Ephemeroptera, Plecoptera, and Trichoptera to sediment stress in the Tsitsa River and its tributaries, Eastern Cape, South Africa. River Res. Applic. p.1-14, 2019.

ALBERTONI, E. F.; SILVA, C. P. Caracterização e importância dos invertebrados de águas continentais com ênfase nos ambientes de Rio Grande. Cadernos de Ecologia Aquática, v.5,n.1p.9-27, 2010.

AMARAL, P. H. M.; SILVEIRA, L. S.; ROSA, B. F. J.; OLIVEIRA, V. C.; ALVES, R. G. Influence of habitat and land use on the assemblages of Ephemeroptera, Plecoptera, and Trichoptera in Neotropical streams. Journal of Insect Science, v.15, n.1, p.1-7, 2015.

ANDRADE, A. L.; BRASIL, L. V.; BENONE, N. L.; SHIMANO, Y.; FARIAS, A. P. J.; MONTAGA, L. F.; DOLÉDEC, S.; JUEN, L. Influence of oil palm monoculture on the taxonomic and functional composition of aquatic insect communities in eastern Brazilian Amazonia. Ecological Indicators, v.82, p.478-483, 2017.

BAPTISTA, D. F.; BUSS, D. F.; DIAS, L. G.; NESSIMIAN, J. L.; SILVA, E. R.; NETO, A. H. M.; ANDRADE, L. R. Functional feeding groups of Brazilian Ephemeroptera nymphs: ultrastructure of mouthparts. International Journal of Limnology, v.42, n.87-96, 2006.

BARQUÍN, J.; SCARSBROOK, M. Management and conservation strategies for coldwater springs. Aquatic Conserv: Mar. Freshw. Ecosyst. v.18, n.580-591, 2008.

BEAUGER, A.; LAIR, N.; REYES-MARCHANT, P.; PEIRY, J. L. 2006. The distribution of macroinvertebrate assemblages in a reach of the River Allier (France), in relation to riverbed characteristics. Hydrobiologia, v.571, p.63-76.

BÊCHE, L. A.; STATZNER, B. Richness gradients of stream invertebrates across the USA: taxonomy- and trait-based approaches. Biodivers Conserv.18:3909-3930, 2009.

BIHN, J.; GEBAUER, G.; BRAND, A. Loss of functional diversity of ant assemblagesin secondary tropical forests. Ecology. v.91, n.3, p.782-792, 2010.

BOUCHARD, R. W. J. R. Guide to aquatic macroinvertebrates of the Upper

Midwest. Water Resources Center, University of Minnesota, St. Paul, MN. 208p, 2004. 
BOTELHO, S. A.; DAVIDE, A. C. Métodos silviculturais para a recuperação de nascentes e recomposição de matas ciliares. Simpósio Nacional de Áreas Degradadas, Belo Horizonte, Brasil. p.18-22, 2002.

BRASIL. Law 12,651/2012. 2012. Diário Oficial da União, Brasília, Distrito Federal. $1: 1$.

BRITO, R. N. R, NILS, N. D.; BEASLEY, C. R.; SANTOS, H. S. S. Características sedimentares fluviais associadas ao grau de preservação da mata ciliar - Rio Urumajó, nordeste paraense. Acta Amazônica. v.39, n.1, p.173-180, 2009.

BROCKERHOFF, E. G.; JACTEL. H.; PARROTTA, J. A.; FERRAZ, S. F. B. Role of eucalypt and other planted forest in biodiversity conservation and the provision of biodiversity-related ecosystem services. For. Ecol. Manag. v.301, p.43-50, 2013.

BRYCE, S. A.; LOMNICKY, G. A.; KAUFMANN, P. R. Protecting sedimentsensitive aquatic species in mountain streams through the application of biologically based streambed sediment criteria. Journal of the North American Benthological Society. v.29, p.657-672, 2010.

BUCHWALTER, D. B.; JENKINS, J. J.; CURTIS, L. R. Respiratory strategy is a major determinant of $[3 \mathrm{H}]$ water and $[14 \mathrm{C}]$ chlorpyrifos uptake in aquatic insects. Can. J. Fish. Aquat. Sci. v.59, p.1315-1322, 2002.

CALOR, A. R.; FROEHLICH, C. G. Description of the immature stages of Notalina morsei Holzenthal, 1986 (Trichoptera: Leptoceridae) and an updated key to larvae of Neotropical Leptoceridae genera. Zootaxa, v.17, p.45-54, 2008.

CANTONATI, M.; BERTUZZI, E.; SPITALE, D. The spring habitat: biota and sampling methods. Monografie del Museo Tridentino Scienze Naturali. 4:1-350, 2007.

CANTONATI, M.; FÜREDER, L.; GERECKE, R.; JÜTTNER, I.; COX, E. J. Crenic habitats, hotspots for freshwater biodiversity conservation: toward an understanding of their ecology. Freshwater Science, v.21, p.463-480, 2012.

CARLSON, P. E.; JOHNSON, R. K.; MCKIE, B. G. Optimizing stream bioassessment: habitat, season, and the impacts of land use on benthic macroinvertebrates.

Hydrobiologia, v.704, p.363-373, 2013.

CARVALHO, R. A.; TEJERINA-GARRO, F. L. Environmental and spatial processes: what controls the functional structure of fish assemblages in tropical rivers and headwater streams? Ecol Freshwater Fish, v.4, p.317-328, 2015.

COLZANIL, E.; SIQUEIRA, T.; SURIANO, M. T.; ROQUE, F. O. Responses of aquatic insect functional diversity to landscape changes in Atlantic Forest. Biotropica, v.45, n.3, p.343-350, 2013. 
CORDERO-RIVERA, A.; ÁlVAREZ, M. A.; ÁLVAREZ, M. Eucalypt plantations reduce the diversity of macroinvertebrates in small forested streams. Animal Biodiversity and Conservation, v.40, n.1, p.87-97, 2017.

CUNHA, E. J.; MONTANG, L. F. A.; JUEN, L. Oil palm crops effects on environmental integrity of Amazonia stream and Heteroteran (Hemiptera) species diversity. Ecol. Indic. v.52, p.422-429, 2015.

DE CACERES M, JANSEN F. 2015. Package 'indicspecies'. Site $<$ https://vegmod.github.io/software/indicspecies>

DE CASTRO, D. M. P.; DOLÉDEC, S.; CALLISTO, M. Landscape variables influence taxonomic and trait composition of insect assemblages in Neotropical savanna streams. Freshwater Biology, p.1-15, 2017.

DEDIEU, N.; RHONE, M.; VIGOUROUX, R.; CÉRÉGHINO, R. Assessing the impact of gold mining in headwater stream of Eastern Amazonia using Ephemeroptera assemblages and biological traits. Ecological Indicators, v.52, p.332-340, 2015.

DIAS, S.; CABIDO, M. Vive la différence: plant functional diversity matters to ecosystem processes. Trends in Ecology \& Evolution, v.16, n.11, p.646-655, 2001.

DOLÉDEC, S.; PHILLIPS, N.; TOWNSEND, C. Invertebrate community responses to land use at a broad spatial scale: trait and taxonomic measures compared in New Zealand rivers. Freshwater Biology. v.56, p.1670-1688, 2011.

DUFRENE, M.; LEGENDRE, P. Species assemblages and indicator species: the need for a flexible asymmetrical approach. Ecol. Monogr. v.67, p.345-366, 1997.

FERREIRA, A. R.; NETTO, A. O. R.; SANTOS, T. I. S.; SANTOS, B. L.; MATOS, E. L. The sub-basin springs of Poxim river, state of Sergipe: the degradation to restoration. Rev. Árvore. v.35, n.2, 2011.

FERREIRA, V.; KORICHEVA, J.; POZO, J.; GRAÇA, M. A. S. A meta-analysis on the effects of changes in the composition of native forests on litter decomposition in streams. Forest Ecology and Management, v.364, p.27-38, 2016.

FITZHERBERT, E. B.; STRUEBIG, M. J.; MOREL, A.; DANIELSEN, F.; BRÜHL C. A.; DONALD, P. F.; PHALAN, B. How will oil palm expansion affect biodiversity? Trends Ecol. Evol. v.23, p.538-545, 2008.

FOSTER, W. A.; SNADDON, J. L.; TURNER, E. C.; FAYLE, T. M.; COCKERILL, T. D.; ELWOOD, M. D.; BROAD, G. R.; CHUNG, A. Y. C.; EGGLETON, P.; KHEN, C. V. Establishing the evidence base for maintaining biodiversity and ecosystem function in the oil palm landscapes of South East Asian. Phil. Trans. R. Soc. v.366, p.32773291, 2011.

FOX, J.; WEISBERG, S. 2019. An R Companion to Applied Regression. $3^{\circ}$ Edition, Sage, in press. 
FRANÇA, J.; MORENO, P.; CALLISTO, M. Importância da composição granulométrica para a comunidade bentônica e sua relação com o uso e ocupação do solo na bacia hidrográfica do rio das Velhas. In: Encontro Nacional de Engenharia de Sedimentos. Porto Alegre. Anais... Porto Alegre: ENES, 2006.

GIMENEZ, B. C. G.; HIGUTI, J. Land use effects on the functional structure of aquatic insect communities in Neotropical streams. Inland Waters, v.7, n.3, p.305-313, 2017.

GOOGLE. 2017. Google Earth. Google, Inc.

GOWER, J. C. Some distance properties of latent root and vector methods used in multivariate analysis. Biometrika, v.53, p.325-338, 1966.

GRAÇA, M. A. S.; POZO, J.; CANHOTO, C.; ELÓSEGI, A. Effects of Eucalyptus globulus plantations on detritus, decomposers, and detritivores in streams. The Scientific World Journal, v.2, p.1173-1185, 2002.

HARE, L. Aquatic insects and trace metals: bioavailability, bioaccumulation, and toxicity. Crit. Rev. Toxicol, v.22, p.327-369, 1992.

HUGHES, R. M.; PECK, D. V. Acquiring data for large aquatic resource surveys: the art of compromise among science, logistics, and reality. Journal of the North American Benthological Society, v.27, p.837-859, 2008.

LALIBERTÉ, E.; LEGENDRE, P. A distance-based framework for measuring functional diversity from multiple traits. Ecology, v.91, p.299-305, 2010.

LAMOUROUX, N.; DOLÉDEC, S.; GAYRAUD, S. Biological traits of stream macroinvertebrate communities: effects of microhabitat, reach, and basin filters. Journal of the North American Benthological Society, v.23, n.3, p.449-466, 2004.

LARRAÑAGA, A.; BASAGUREN, A.; ELOSEGI, A.; POZO, J. Impacts of Eucalyptus globules plantations on Atlantic streams: changes in invertebrate density and shredder traits. Fund. Applied Limnol. Archiv für Hydro. v.175, p.151-160, 2009.

LAWTON, J. H.; BROWN, V. K. Redundancy in ecosystems. Springer, New York, p.255-268, 1993.

LEGENDRE, P.; LEGENDRE, L. Numerical ecology. 2nd English edition. Elsevier Scientific Publishing Company, Amsterdam, The Netherlands, 1998.

LENCIONI, L.; MARZIALI, L.; ROSSARO, B. Chironomids as bioindicators of environmental quality in mountain springs. Freshwater Science, v.31, n.2, p.525-541, 2012.

LONGHI, M.; BEISNER, B. E. Patterns in taxonomic and functional diversity of lake phytoplankton. Freshwater Biology, v.55, p.1349-1366, 2010. 
MAIOLINI, B.; CAROLLI, M.; SILVERI, L. Ephemeroptera, Plecoptera and Trichoptera in springs in Trentino (south-eastern Alps). J. Limnol, v.70, p.122-133, 2011.

MAYFIELD, M. M.; BONSER, S. P.; MORGAN, J. W.; AUBIN, I.; MCNAMARA, S.; VESK, P. A. What does species richness tell us about functional trait diversity? Predictions and evidence for responses of species and functional trait diversity to landuse changegeb. Global Ecology and Biogeography, v.19, p.423-431, 2010.

OLIFIERS, M. H.; DORVILLÉ, L. F. M.; NESSIMIAN, J. L.; HAMADA, N. A key to Brazilian genera of Plecoptera (insecta) based on nynphs. Zootaxa. v.65, p.1-15, 2004.

OKSANEN, J.; BLANCHET, F. G.; KINDT, R.; LEGENDRE, P.; MINCHIN, P. R.; O'HARA, R. B.; WAGNER, H. 2016. Vegan: Community Ecology Package. R package Version 3.0-2.

OVERBECK, G. E.; VÉLEZ-MARTIN, E.; SCARANO, F. R.; LEWINSOHN, T. M.; FONSECA, C. R.; MEYER, S. T.; MÜLLER, S. C.; CEOTTO, P.; DADALT, L.; DURIGAN, G.; GANADE, G.; GOSSNER, M. M.; GUADAGNIN, D. L.; LORENZEN, K. L.; JACOBI, C. M.; WEISSER, W. W.; PILLAR, V. D. Conservation in Brazil needs to include non-forest ecosystems. Diversity Distrib. v.21, p.1455-1460, 2015.

PEEL, M. C.; FINLAYSON, B. L.; MCMAHON, T. A. Updated world map of the Köppen Geiger climate classification. Hydrol. Earth Syst. Sci. Discuss. v.4, p.439-473, 2007.

PES, A. M. O. Taxonomia, estrutura e riqueza das assembleias de larvas e pupas de Trichoptera (Insecta), em igarapés na Amazônia central. Ph.D., Instituto Nacional de Pesquisas da Amazônia, Universidade Federal de Manaus, Manaus, Brazil, 165p.

PES, A. M. O.; HAMADA, N.; NESSIMIAN, J. L. Chaves de identificacão de larvas para famílias e gêneros de Trichoptera (Insecta) da Amazônia Central, Brasil. Rev. Bras. Entomol. v.49, p.181-204, 2005.

PETCHEY, O. L.; GASTON, K. J. Functional diversity: back to basics and looking forward. Ecology Letters. v.9, p.741-758, 2006.

PILIÈRE, A. F. H.; VERBERK, W. C. E. P.; GREAWE, M.; BREURE, A. M.; DYER, S. D.; POSTHUMA, L.; ZWART, D.; HUIJBREGTS, M. A. J.; SCHIPPER, A. M. On the importance of trait interrelationships for understanding environmental responses of stream macroinvertebrates. Freshwater Biolo. p.1-14, 2015.

PINTO, R.; JUNIOR, J. S. Z.; ZANUNCIO, T. V.; ZANUNCIO, J. C.; LACERDA, M. C. Coleópteros coletados com armadilhas luminosas em plantios de Eucalyptus urophylla na região amazônica brasileira. Ciência Florestal, v.14, p.111-119, 2004.

PJF - PREFEITURA DE JUIZ DE FORA, MINAS GERAIS. 1996. Plano Diretor de Juiz de Fora. Juiz de Fora: Concorde. $<$ https://leismunicipais.com.br/plano-diretorjuiz-de-fora-mg>. 
PJF - PREFEITURA DE JUIZ DE FORA, MINAS GERAIS. 2001. Anuário estatístico de Juiz de Fora 2001: base de dados 2000. Centro de Pesquisas Sociais, Juiz de Fora, p 80 .

POFF, N. L. R.; OLDEN, J. D.; NICOLE, K. M.; VIEIRA, D. S.; SIMMONS, F. M. P.; KONDRATIEFF, B. C. Functional trait niches of North American lotic insects: traitsbased ecological applications in light of phylogenetic relationships. J. N. Am. Benthol. Soc. v.25, n.4, p.30-75, 2006.

R CORE TEAM. 2016. R: A Language and Environment for Statistical Computing. R Foundation of Statistical Computing, Vienna.

RIBERA, I.; DOLÉDEC, S.; DOWNIE, I. S.; FOSTER, G. N. Effect of land disturbance and stress on species traits of ground beetle assemblages. Ecology, v.82, p.1112-1129, 2001.

RASBAND, W. S. 2012. ImageJ. U. S. National Institutes of Health, Bethesda, MD.

SALLES, F. F. A ordem Ephemeroptera no Brasil (insecta): taxonomia e diversidade. Ph.D. Thesis, Universidade Federal de Viçosa, Viçosa, Brasil. p 108, 2006.

SATO, J. Mata Atlântica: direito ambiental e a legislação - exame das restrições ao uso da propriedade. Hemus, p.40, 1995.

SAVIĆ, A.; DMITROVIĆ, D.; PEŠIĆ, V. Ephemeroptera, Plecoptera, and Trichoptera assemblages of karst springs in relation to some environmental factors: a case study in central Bosnia and Herzegovina. Turk J. Zool. v.41, p.119-129, 2017.

SCANLON, B. R.; JOLLY, I.; SCANLON, B. R.; SOPHOCLEOUS, M.; ZHANG, L.; Global impacts of conversions from natural to agricultural ecosystems on water resources: quantity versus quality. Water Resources Research. 43p, 2007.

SCARSBROOK, M.; BARQUÍN, J.; GRAY, D. New Zealand coldwater springs and their biodiversity. Science for Conservation. 72p, 2007.

SCHLEUTER, D.; DAUFRESNE, M.; MASSOL, F.; ARGILLIER, C. A user's guide to functional diversity índices. Ecological Monographs, v.80, n.3, p.469-484, 2010.

STAUDACHER, K.; FÜREDER, L. Habitat Complexity and Invertebrates in Selected Alpine Springs (Schütt, Carinthia, Austria). Internat. Rev. Hydrobiol. v.92, p.465-479, 2007.

STERNER, R. W. Role of zooplankton in aquatic ecosystems. In Likens GE. (ed.), Encyclopedia of inland waters. Elsevier Oxford, UK: p.678-688, 2009.

STRICKLAND, J. D. H.; PARSONS, T. R. A Practical Handbook of Seawater Analysis. Bulletin of Fisheries Research Board of Canada, v.167, p.1-311, 1968. 
SUGANUMA, M. S.; TOREZAN, J. M. D.; CAVALHEIRO, A. L.; VANZELA, A. L. L.; BENATO, T. Comparando metodologias para avaliar a cobertura do dossel e a luminosidade no sub-bosque de um reflorestamento e uma floresta madura. Revista Árvore, v.32, p.377-385, 2008.

TERESA, F. B.; CASATTI, L. Influence of forest cover and mesohabitat types on functional and taxonomic diversity of fish communities in Neotropical lowland streams. Ecology of Freshwater Fish, v.21, p.433-442, 2012.

TILMAN, D.; KNOPS, J.; WEDIN, D.; REICH, P.; RITCHIE, M.; SIEMANN, E. The Influence of functional diversity and composition on ecosystem Processes. Science. $277 \mathrm{p}, 1997$.

TOMANOVA, S.; USSEGLIO-POLATERA, P. Patterns of benthic community traits in neotropical streams: relationship to mesoscale spatial variability. Fundamental and Applied Limnology Archiv für Hydrobiologie, v.170, n.3, p.243-255, 2007.

TOMANOVA, S.; MOYA, N.; OBERDORFF, T. Using macroinvertebrate biological traits for assessing biotic integrity of Neotropical streams. River Research and Applications, v.24, p.1230-1239, 2008.

TOWNSEND, C. R.; DOWNES, B. J.; PEACOCK, K.; ARBUCKLE, C. J. Scale and the detection of land-use effects on morphology, vegetation and macroinvertebrate communities of grassland streams. Freshwater Biology, v.49, p.448-462, 2004.

VALVERDE, S. R.; SOARES, N. S.; SILVA, M. L.; JACOVINE, L. A. G.; NEIVA, S. A. O. Comportamento do mercado da madeira de eucalipto no Brasil. Biomassa \& Energia, v.1, n.4, p.393-403, 2004.

VILLÉGER, S.; MASON, N. W. H.; MOUILLOT, D. New multidimensional functional diversity indices for a multifaceted framework in functional ecology. Ecology, v.89, p. 2290-2301, 2008.

WETZEL, R. G.; GENE, E. Likens: limnological analyses. 3rd edn. Int. Microbiol. v.4, p.179-180, 2001.

WILLIAMS, N. M., E. E. CRONE, T. H. ROULSTON, R. L. MINCKLEY, L. PACKER, AND S. G. POTTS. Ecological and life-history traits predict bee species responses to environmental disturbances. Biological Conservation, v.143, p.22802291, 2010.

WONG, M. C.; DOWD, M. Patterns in taxonomic and functional diversity of macrobenthic invertebrates across seagrass habitats: a case study in Atlantic Canada.

Estuar. Coast. p.2323-2336, 2015.

WOOD, P. J.; ARMITAGE, P. D. Biological effects of fine sediment in the lotic environment. Environmental Management, v.21, p.203-217, 1997.

ZALIDIS, G.; STAMATIADIS, S.; TAKAVAKOGLOU, V. ESKRIDGE, K.; MISOPOLINOS, N. Impacts of agricultural practices on soil and water quality in the 
Mediterranean region and proposed assessment methodology. Agriculture, Ecosystems \& Environment. v.88, n.2, p.137-146, 2002.

ZHANG, Y.; CHENG, L.; LI, K.; ZHANG, L.; CAI, Y.; WANG, X.; HEINO, J. Nutrient enrichment homogenizes taxonomic and functional diversityof benthic macroinvertebrate assemblages in shallow lakes. Limnol. Oceanogr. v.64, p.1047$1058,2019$. 


\section{CAPÍtUlO 3: A VARIAÇÃO SAZONAL PLUVIOMÉTRICA EM NASCENTES TROPICAIS INFLUENCIA A DIVERSIDADE BETA DE INSETOS EM ÁREAS COM DIFERENTE USO DA TERRA?}

\section{RESUMO}

A variação sazonal de períodos secos e chuvosos é um fator importante de perturbação dos ecossistemas aquáticos, e seu efeito na fauna bentônica tem sido amplamente estudado em ecossistemas fluviais. Contudo, poucos estudos buscam investigar o efeito perturbador da sazonalidade pluviométrica em nascentes com diferente uso da terra. Desta forma, empregamos a diversidade beta e seus componentes substituição (turnover) e perda de espécies (aninhamento), utilizando as assembleias de Ephemeroptera, Plecoptera e Trichoptera (EPT) para verificar o efeito dos períodos sazonais seco e chuvoso na estabilidade ambiental de nascentes tropicais em áreas de floresta e de eucalipto. Testamos a hipótese de maior variação da diversidade beta em áreas de eucalipto, e o componente substituição de espécies predominante em ambas as áreas, devido a heterogeneidade ambiental de nascentes. Para tanto, em uma série temporal de três anos, durante os períodos secos e chuvosos do ano, utilizamos um amostrador de rede de mão para coletar o substrato de nascentes perenes em áreas de floresta e eucalipto no sudeste do Brasil. Nossos resultados mostraram que as nascentes estudadas apresentaram estabilidade ambiental entre os períodos secos e chuvosos, não havendo variação significativa da diversidade beta em nascentes em área de floresta e nascentes em área de eucalipto, e devido à heterogeneidade de habitats de nascentes a substituição de espécies foi predominante. Também verificamos homogeneidade dos parâmetros ambientais entre os períodos secos e chuvosos, e apesar da baixa variação da diversidade beta a variável areia fina, condutividade e turbidez foram os melhores preditores em áreas de floresta e eucalipto, respectivamente. $\mathrm{O}$ eucalipto em conjunto com a vegetação ciliar natural, mesmo que às vezes reduzida, mostrou-se relevante na manutenção da diversidade beta de EPT entre os períodos secos e chuvosos, mostrando a importância da conservação da vegetação ciliar em nascentes de áreas cultivadas.

Palavras-chave: Aninhamento; bentos; EPT; eucalipto; insetos aquáticos; turnover. 


\begin{abstract}
Seasonal variation of dry and rainy periods is an important factor in disturbing aquatic ecosystems, and its effect on benthic fauna has been widely studied in river ecosystems. However, few studies seek to investigate the disturbing effect of rainfall seasonality in springs with different land use. Thus, we used the beta diversity and its replacement (turnover) and species loss (nestedness) components, using Ephemeroptera, Plecoptera and Trichoptera (EPT) assemblages to verify the effect of dry and rainy seasonal periods on the environmental stability of tropical springs in forest areas and eucalyptus areas. We tested the hypothesis of greater variation in beta diversity in eucalyptus areas, and the predominant species replacement component in both areas, due to environmental heterogeneity of springs. For that, in a three-year time series, during the dry and rainy periods of the year, we used a hand net sampler to collect the substrate from perennial springs in forest and eucalyptus areas in southeastern Brazil. Our results showed that the studied springs presented environmental stability between the dry and rainy periods, with no significant variation of beta diversity in springs in forest area and springs in eucalyptus area, and due to the heterogeneity of spring habitats, the turnover of species was predominant. We also verified homogeneity of environmental parameters between the dry and rainy periods, and despite the low variation of beta diversity, the fine sand variable, conductivity and turbidity were the best predictors in forest and eucalyptus areas, respectively. The eucalyptus planted for more than ten years together with the natural riparian vegetation, even if sometimes reduced, proved to be relevant in maintaining the beta diversity of EPT between the dry and rainy periods, showing the importance of conservation of riparian vegetation in springs of cultivated areas.
\end{abstract}

Keywords: Turnover; benthic; EPT; eucalyptus; aquatic insects; nestedness. 


\subsection{INTRODUÇÃO}

Ecossistemas de água doce podem ser afetados por fatores associados a fenômenos naturais, a intervenção antrópica ou pela combinação de ambos (LAKE, 2000). Distúrbios naturais, como as flutuações sazonais de clima com estações secas e chuvosas, tem papel importante na estruturação das comunidades aquáticas em regiões tropicais (MORAES et al., 2005; BISPO et al., 2006). Períodos sazonais secos e de fortes chuvas exercem alterações nos principais parâmetros associados à distribuição da fauna aquática como vazão, disponibilidade de microhabitats e condições físicas e químicas dos corpos d'água (DEATH; WINTERBOURN, 1995; ZARDO et al., 2013). Estas alterações podem ser mais pronunciadas em ambientes aquáticos sujeitos à influência de atividades antrópicas (MARMONTEL et al., 2018). Helms; Schoonover; Feminella (2009) verificaram em riachos com diferentes tipos de uso da terra no Oeste dos Estados Unidos, que a influência dos pulsos de inundações durante períodos chuvosos era mais pronunciada em áreas de menor integridade ambiental, levando a alterações das condições físicas e químicas da água, reduzindo a heterogeneidade de habitats e a riqueza da fauna bentônica. Embora esteja bem documentado que perturbações naturais (DEATH; WINTERBOURN, 1995; YOKOYAMA et al., 2012) e antrópicas (CARLSON et al., 2013; RODRIGUES et al., 2018) em riachos, podem alterar a estabilidade do canal, os parâmetros físicos e químicos da água e a diversidade da comunidade aquática (OLIVEIRA et al., 1997; HELMS; SCHOONOVER; FEMINELLA, 2009), distúrbios naturais (ZARDO et al., 2013) e antrópicos (SADA; FLEISHMAN; MURPHY, 2005) sobre a estabilidade ambiental e diversidade da fauna bentônica de nascentes tropicais ainda são pouco conhecidos.

As nascentes são ecossistemas aquáticos únicos devido à sua estrutura ecotonal entre a água subterrânea, águas superficiais e o ambiente terrestre (VON FUMETTI; BLATTNER, 2017). Apesar de suas dimensões reduzidas, apresentam elevada heterogeneidade de habitats, contribuindo consideravelmente para a diversidade local e regional de espécies (CANTONATI; GERECKE; BERTUZZI, 2006). Nascentes podem apresentar condição ambiental estável (WILLIAMS, 1991a; ABDELSALAM; TANIDA, 2013), principalmente devido a sua relativa constância térmica (WILLIAMS, 1991a) e estabilidade do fluxo de água (SMITH; WOOD, 2002). No entanto, a frequência e intensidade de perturbações promovida pelas condições de secas e chuvas são fatores temporais importantes que influenciam a estabilidade e permanência das 
espécies em nascentes (MYERS; RESH, 2002). Von Fumetti et al. (2006) estudaram nascentes na Suíça e verificaram que o aumento da vazão em períodos de maior precipitação, foi o fator que melhor contribuiu para a composição das assembleias de macroinvertebrados.

Nos últimos anos, com a expansão da silvicultura do eucalipto em regiões tropicais, para fins de produção e extração de madeira, tem aumentado a homogeneização e fragmentação da vegetação natural (BROCKERHOFF, 2013), levando a redução da riqueza da fauna bentônica de nascentes (AMARAL el al., 2021; REISS; CHIFFLARD, 2018). A conversão de florestas nativas em plantações de eucalipto pode aumentar o escoamento superficial, provocando erosão do solo, que consequentemente, causa a alteração dos parâmetros físicos e químicos e a redução da taxa de recarga das águas subterrâneas (CORDERO - RIVERA et al., 2017) que abastecem as nascentes. Assim sendo, corpos d'água cujas áreas circunvizinhas são cobertas por plantações de eucalipto podem ter seu volume de água comprometido durante períodos de estiagem (JACKSON et al., 2005). Portanto, variações sazonais de precipitação e o uso da terra devem ser considerados em estudos que busquem analisar os fatores que influenciam os padrões de diversidade da fauna bentônica de ecossistemas de nascente.

Um grupo amplamente utilizado como indicadores ecológicos de ecossistemas aquáticos, devido à sua sensibilidade às mudanças ambientais são as assembleias de Ephemeroptera, Plecoptera e Trichoptera (EPT) (BISPO et al. 2006; SUHAILA; SALMAH; AL-SHAMI, 2012; SOUZA et al. 2020). Amaral, Rocha; Alves (2021) verificaram a redução da riqueza e alteração na composição de assembleias de EPT em nascentes tropicais brasileiras em áreas plantadas com eucalipto. Em outro estudo, Myers e Resh (2012) observaram que, temporalmente, Trichoptera sofria baixa variação na riqueza ao longo do ano, devido principalmente à estabilidade do fluxo de água das nascentes. $\mathrm{O}$ uso de grupos taxonômicos sensíveis a mudanças ambientais, como as assembleias de EPT (ANDRADE et al., 2017; DE CASTRO et al., 2017) pode gerar respostas da biota aquática às perturbações naturais e antrópicas em nascentes.

A diversidade beta fornece um meio promissor de estimar e analisar os mecanismos que conduzem as mudanças temporais na distribuição da diversidade das espécies (ZHANG et al., 2018) e na estabilidade do ecossistema (O' GORMAN; EMMERSON, 2009). Em geral, ecossistemas heterogêneos mantêm maior diversidade de espécies e, períodos de maior precipitação podem levar a homogeneização do habitat, 
reduzindo a diversidade (ZHANG et al., 2018). Estudos mostraram que a diversidade beta pode ser particionada em dois componentes ecologicamente distintos, que moldam as comunidades e suas diferenças: a substituição de espécies (turnover) e a perda de espécies (aninhamento) (BASELGA, 2010; CARVALHO et al., 2013). O componente turnover implica na alternância ou substituição de espécies por outras, entre as comunidades (BASELGA, 2010), e está associada principalmente a heterogeneidade ambiental (HEINO et al., 2013; MALOUFI et al., 2016). Por outro lado, o componente aninhamento indica que a perda de espécies em certos locais resulta em um padrão no qual a biota presente é um subconjunto de espécies de locais mais ricos (LEGENDRE, 2014). Assim, com base na partição da diversidade beta, pode-se estabelecer se a variação dos atributos taxonômicos é causada por aninhamento ou substituição de espécies (BASELGA; ORME, 2012), bem como se estes atributos responderão a mudanças sazonais e/ou ambientais (PASSY; BLANCHET, 2007; ROCHA et al., 2018).

Neste contexto, o objetivo do nosso estudo foi verificar se períodos sazonais secos e chuvosos influenciam a diversidade beta das assembleias de Ephemeroptera, Plecoptera e Trichoptera (EPT) de nascentes em áreas de floresta e de eucalipto, na região sudeste do Brasil. Foram analisadas duas questões complementares: (1) Entre períodos secos e chuvosos há diferença na diversidade beta, assim como dos componentes de substituição e aninhamento de gêneros em nascentes de floresta e eucalipto? (2) Nos períodos secos e chuvosos as variáveis ambientais apresentam condições ambientais distintas e, quais são melhores relacionadas à diversidade beta de EPT em nascentes em áreas de floresta e eucalipto? Nossa hipótese é que, devido à heterogeneidade e estabilidade ambiental das nascentes, a composição da assembleia de EPT seja estruturada pelo componente substituição e, períodos secos e chuvosos exerçam maior efeito na variação da diversidade beta em área de eucalipto, dado que a preservação da vegetação natural tende a reduzir o efeito da sazonalidade em nascentes em áreas de floresta. 


\subsection{MATERIAL E MÉTODOS}

\subsection{1 Área de Estudo}

O estudo foi conduzido em nascentes pertencentes à sub-bacias do rio Paraíba do Sul, região Sudeste do estado de Minas Gerais, Brasil. Todas as nascentes estão localizadas em quatro propriedades particulares (A, B, C e D) cuja silvicultura do eucalipto (Eucalyptus urograndis) é predominante e ultrapassam os dez anos de plantio. A figura 10 indica a localização das áreas A (2137'33,12 "S e 43¹6'53,67" O), B

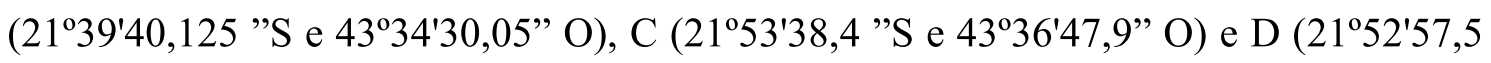
"S e 4336'13,5" O). A região de estudo está inserida no domínio de Floresta Atlântica, classificada como Floresta Estacional Semidecidual Montana (Sato, 1995). O clima é classificado como Cwb de acordo com o sistema Köppen (PEEL; FINLAYSON; MCMAHON, 2007), ou seja, clima tropical de altitude, com precipitação concentrada entre outubro e abril, e períodos secos entre maio e setembro (PJF, 1996). A precipitação anual é de aproximadamente $1.500 \mathrm{~mm}$ e a temperatura média anual está em torno de $19^{\circ} \mathrm{C}$ (PJF, 2001). 
Figura 10 - Localização das nascentes em áreas de floresta e nascentes em área de eucalipto nas sub-bacias hidrográficas do rio Paraíba do Sul, estado de Minas Gerais, Brasil.

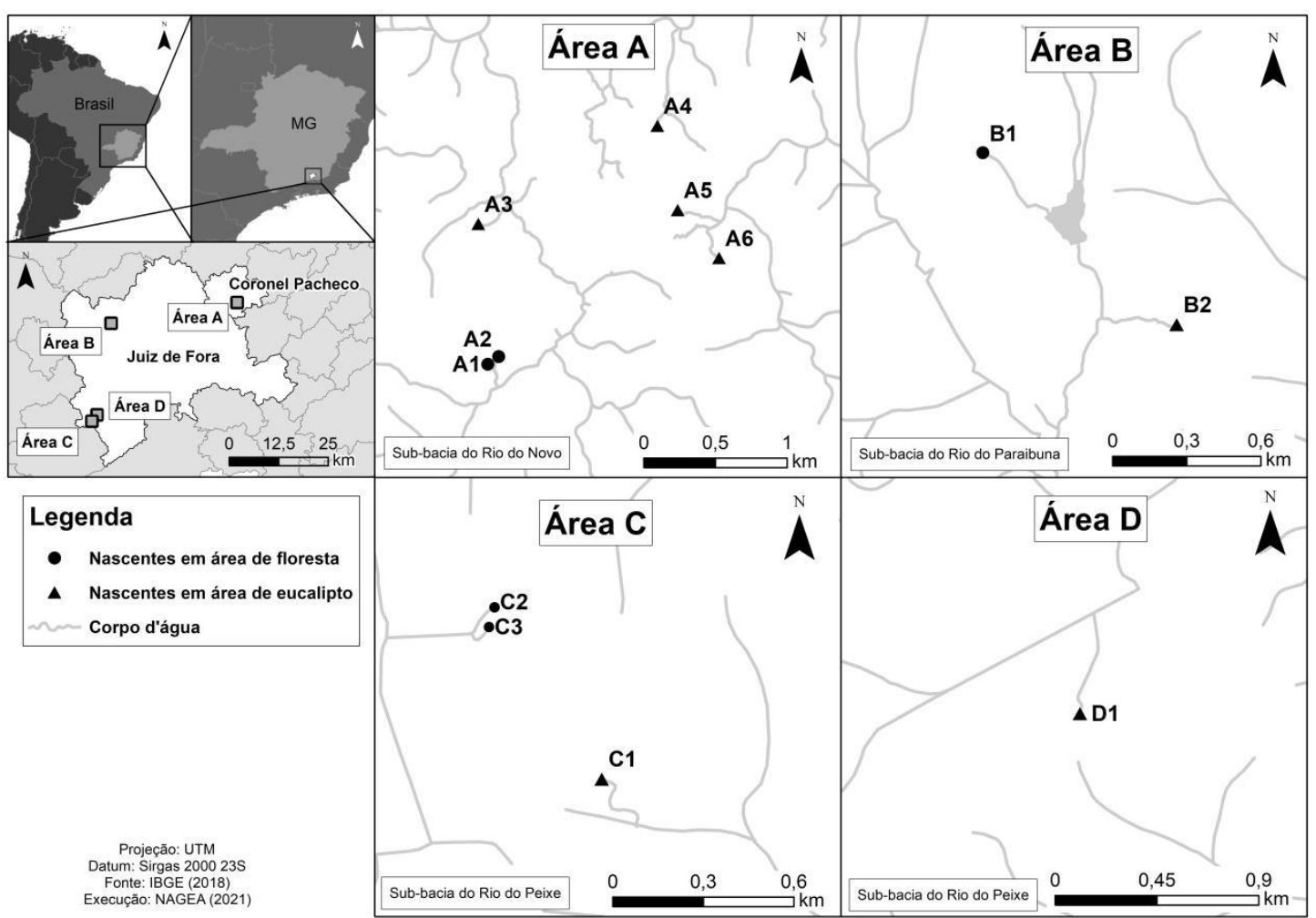

Fonte: Os autores (2021).

\subsubsection{Coleta e identificação da fauna}

Nós amostramos imaturos de EPT no período seco (julho de 2017, 2018 e 2019) e de chuva (janeiro de 2018, 2019 e 2020). Para cada período do ano foram coletadas 12 nascentes, 7 nascentes em áreas plantadas com eucalipto e 5 nascentes em áreas de floresta, protegidas por lei $\mathrm{n}^{\mathrm{o}} 12$. 651/2012 (BRASIL, 2012). Obtivemos os dados pluviométricos para os diferentes meses dos anos para a região estudada (Figura 11). 
Figura 11 - Média mensal de janeiro a dezembro da precipitação pluviométrica dos anos de 2017, 2018, 2019 e 2020 para a região de Juiz de Fora, sudeste do Brasil.

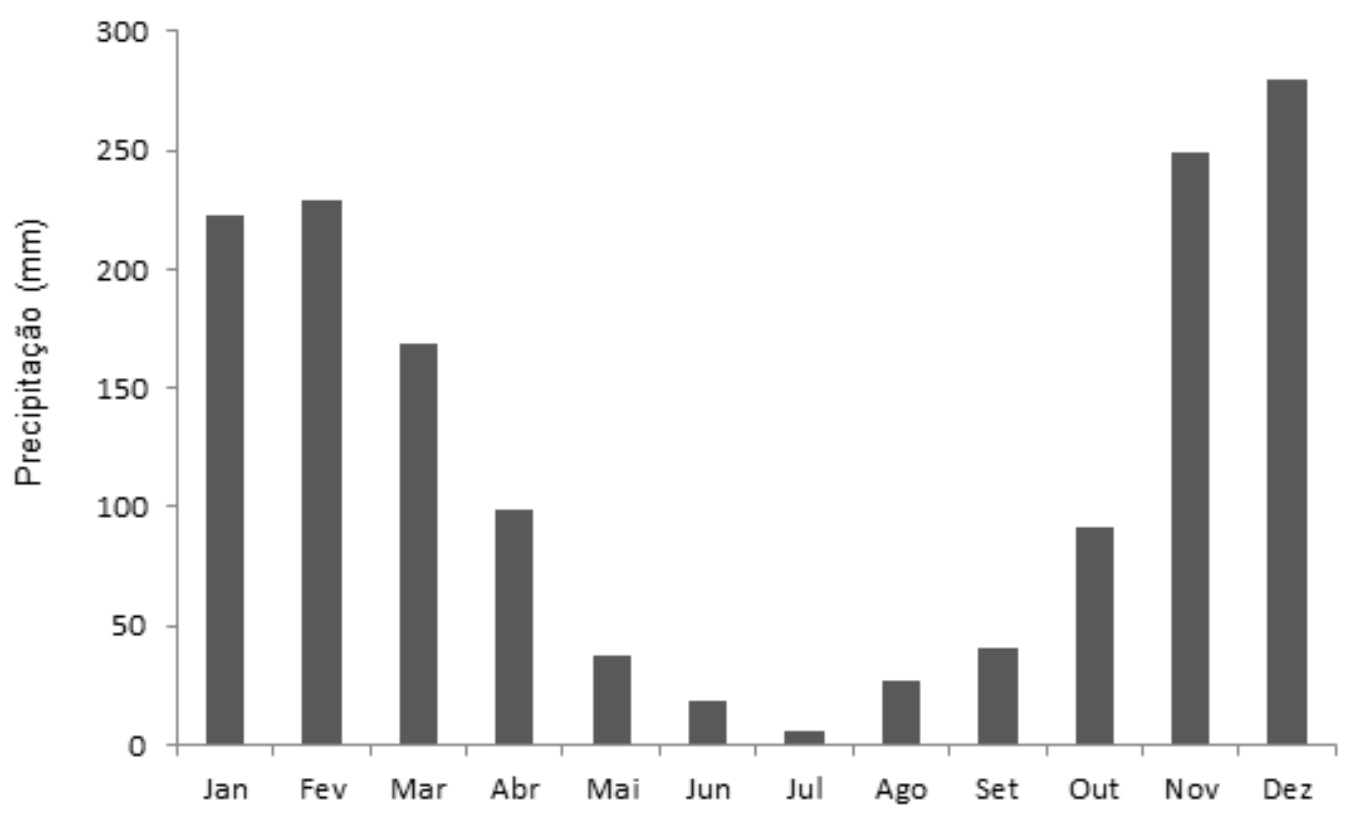

Fonte: Os autores (2021).

Para cada nascente foi estabelecido um transecto de 5 metros a partir da fonte de exfiltração, e coletada três unidades de subamostras composta dos principais substratos (pedra, areia e folhiço) usando um amostrador rede de mão (área de $0,01 \mathrm{~m}^{2}$ e malha de $250 \mu \mathrm{m}$ ) especificamente projetada para coleta em nascentes (LENCIONI; MARZIALI; ROSSARO, 2012). Para cada ponto de coleta foram feitos arrastos longitudinais da jusante para a montante por 15 segundos, totalizando 45 segundos por unidade amostral. As amostras de substrato para análise da fauna foram conservadas individualmente em álcool $85 \%$ e levadas ao laboratório. Em cada nascente, uma segunda amostra do substrato foi coletada para análise de granulometria e matéria orgânica.

No laboratório as amostras foram lavadas em água corrente sobre peneira (malha de $1 \mathrm{~mm}$ ) e os espécimes de EPT foram identificados em nível de gênero sob microscópio estereoscópico, com exceção de ninfas de Baetidae (Ephemeroptera), que foram montadas em lâminas e identificadas em microscópio óptico. As seguintes chaves foram utilizadas para a identificação: Bouchard (2004) e Salles (2006) para Ephemeroptera; Olifiers et al. (2004) para Plecoptera; Pes (2005), Pes; Hamada e Nessimian (2005) e Calor e Froehlich (2008) para Trichoptera. Após identificação, os espécimes foram colocados em frascos de vidro contendo álcool $75 \%$ e mantidos no 
Laboratório de Invertebrados Bentônicos (LIB) da Universidade Federal de Juiz de Fora, Minas Gerais.

\subsubsection{Variáveis Ambientais}

Todas as nascentes selecionadas para este estudo tiveram suas coordenadas e altitude obtidas por GPS - Garmin MAP 76CSx. A porcentagem de abertura do dossel para cada nascente foi obtida através de fotografias digitais (SUGANUMA et al., 2008) distante $10 \mathrm{~cm}$ acima da superfície de cada nascente. As imagens, previamente convertidas em preto e branco, foram analisadas pelo software ImageJ (RASBAND, 2012). O resultado obtido foi um valor médio em pixels, que variou de 0 (cobertura total) a 255 pixels (entrada total de luz). Os valores obtidos foram convertidos em porcentagem.

Foram aferidas na zona de extrusão de cada nascente os valores das variáveis temperatura $\left({ }^{\circ} \mathrm{C}\right)$, condutividade $(\mu \mathrm{S} / \mathrm{cm})$, turbidez (NTU), $\mathrm{pH}$ e oxigênio dissolvido (mg/L) usando uma sonda multiparâmetros - Pró DSS YSY. A profundidade de cada nascente foi medida com uma régua e a largura com uma trena. A vazão da água foi medida através do método volumétrico (BORTOLUZZI; FERNANDEZ, 2008), que consiste no tempo gasto para que o fluxo de água preencha um recipiente com volume conhecido. $\mathrm{O}$ valor da vazão $\left(\mathrm{m}^{3} / \mathrm{s}\right)$ resultou da média de três medidas realizadas dentro dos $5 \mathrm{~m}$ estabelecido para cada nascente.

Para caracterização granulométrica, $120 \mathrm{~g}$ foram separadas e peneiradas em agitador mecânico (SOLOTEST), por tempo padronizado de 30 minutos e 3 de frequência, em um conjunto de peneiras de teste analítico (malha de $2 \mathrm{~mm}$ a $75 \mu \mathrm{m}$ ) e classificadas em cinco frações: areia muito grossa $(1 \mathrm{~mm}<\mathrm{x}<2 \mathrm{~mm})$, areia grossa $(500 \mu \mathrm{m}<\mathrm{x}<1 \mathrm{~mm})$, areia média $(250 \mu \mathrm{m}<\mathrm{x}<500 \mu \mathrm{m})$, areia fina $(150 \mu \mathrm{m}<\mathrm{x}<250$ $\mu \mathrm{m})$, areia muito fina $(75 \mu \mathrm{m}<\mathrm{x}<150 \mu \mathrm{m})$ e silte/argila $(<75 \mu \mathrm{m})$ de acordo com o procedimento recomendado pela norma técnica NBR 7181 (ABNT,1984). O sedimento de cada fração de tamanho foi pesado em balança de precisão (SHIMADZU AUY220) com saldo analítico $0,001 \mathrm{~g}$. Parte do sedimento coletado $(3 \mathrm{~g})$ de cada amostra foi separada para determinação do teor de matéria orgânica conforme a norma técnica NBR 13600 (ABNT, 1996). 


\subsubsection{Análise dos Dados}

A estrutura das assembleias de EPT nos períodos sazonais secos e chuvosos de nascentes em áreas de floresta e nascentes em áreas de eucalipto foi analisada quanto ao número de gêneros e abundância. Para verificar se houve diferença nos valores destes atributos entre os períodos sazonais foi aplicado o teste $t$ (amostras independentes). A análise SIMPER (porcentagem de similaridade), com dados de abundância, foi utilizada para identificar os gêneros de EPT que apresentaram a maior contribuição da abundância entre os períodos secos e chuvosos de nascentes em áreas de floresta e nascentes em áreas de eucalipto.

A análise de dispersão multivariada (PERMIDISP; ANDERSON, 2006) foi utilizada para verificar se a diversidade beta dos gêneros de EPT de nascentes em áreas de floresta e áreas de eucalipto difere entre os períodos sazonais secos e chuvosos. A análise, baseia na distância entre as unidades amostrais e o centroide de um grupo, em um espaço multidimensional de uma análise de coordenadas principais (PCoA), realizada no presente estudo por meio de uma medida de dissimilaridade de Sørensen (dados de presença e ausência) e pelo índice de Bray-Curtis (dados de abundância). Assim, quanto maior a dissimilaridade média dentro dos grupos, maior a diversidade beta. Os valores de significância $(\mathrm{p}<0,05)$ foram calculados por meio de teste de permutação, com 999 aleatorizações, que foram utilizados para gerar um valor de F, sob a hipótese nula de não haver diferença da diversidade beta das nascentes entre os períodos sazonais. As análises foram realizadas usando a função vegdist e betadisper do pacote vegan.

Para verificar a contribuição do componente substituição e aninhamento da diversidade beta entre as assembleias de EPT para os períodos sazonais secos e chuvosos das nascentes em áreas de floresta e nascentes em áreas de eucalipto, utilizouse a abordagem de Baselga (2010) que propõe que, a diversidade beta total, calculada pelo índice de Sørensen ( $\beta$ sor), pode ser decomposta em substituição de espécies, que é medida pelo índice de dissimilaridade de Simpson ( $\beta$ sim) e o componente de aninhamento ( $\beta$ nes), que é a perda de espécies. O índice de dissimilaridade e o seus componentes foram obtidas através da função beta.multi do pacote estatístico betapart (BASELGA; ORME, 2012).

A fim de testar a hipótese nula de homogeneidade das variáveis ambientais das nascentes em áreas de floresta e nascentes em áreas de eucalipto para os períodos 
sazonais secos e chuvosos, utilizamos também o teste de homogeneidade e dispersões multivariadas (PERMIDISP), contudo com base na distância euclidiana para o centroide do grupo para dados normalizados (ANDERSON, 2006). As análises foram realizadas usando a função vegdist e betadisper do pacote vegan.

Inicialmente, usamos GLM Poisson, mas por detectar a sobre dispersão da variância usamos o modelo com distribuição Quase-Poisson para verificar quais variáveis melhor explicam a variação da diversidade beta da fauna de EPT nos períodos sazonais secos e chuvosos das nascentes em áreas de floresta e nascentes em áreas de eucalipto. A análise foi iniciada com o modelo global, posteriormente procedeu-se a retirada de variáveis não significativas. O processo foi repetido até que nenhuma variável pudesse ser retirada do modelo (CRAWLEY, 2011).

Todas as análises foram executadas no software $\mathrm{R}$, versão 3.3 .2 ( $\mathrm{R}$ DEVELOPMENT CORE TEAM, 2016), a partir do uso dos pacotes vegan (OKSANEN et al., 2016) Betapart (Baselga et al., 2012) e BAT (CARDOSO et al., 2018).

\subsection{RESULTADOS}

Um total de 9.568 espécimes de Ephemeroptera, Plecoptera e Trichoptera foram identificados durante o estudo, distribuídos em 23 gêneros e 14 famílias. Não houve diferença na riqueza de EPT entre os períodos sazonais secos e chuvosos para nascentes em áreas de floresta $(\mathrm{t}=0.987 \mathrm{gl}=28 \mathrm{p}=0.329)$ e nascentes em áreas de eucalipto $(\mathrm{t}=$ $0.141 \mathrm{gl}=33 \mathrm{p}=0.888$ ). Por outro lado, a abundância diferiu entre os períodos sazonais secos e chuvosos para nascentes em áreas de floresta $(\mathrm{t}=2.152 \mathrm{gl}=28 \mathrm{p}=0.041)$, mas não para nascentes em áreas de eucalipto $(\mathrm{t}=-0.213 \mathrm{gl}=33 \mathrm{p}=0.832)$.

De acordo com a análise de similaridade (SIMPER) os taxa de EPT foram mais abundantes no período sazonal seco para nascentes em áreas de floresta e nascentes em áreas de eucalipto, com exceção dos gêneros Triplectides, Phylloicus, Oecetis e Grumicha que foram mais representativos no período chuvoso em nascentes de áreas de eucalipto (Tabela 7). 
Tabela 7 - Análise de Percentual de Similaridade (SIMPER) com listagem dos 10 primeiros táxons de Ephemeroptera, Plecoptera e Trichoptera mais abundantes nos períodos secos e chuvosos de nascentes em áreas de floresta e eucalipto da bacia do Rio Paraíba do Sul, Sudeste do Brasil.

\begin{tabular}{|c|c|c|}
\hline \multirow[t]{2}{*}{ Táxon } & \multicolumn{2}{|c|}{ Abundância Média } \\
\hline & Seco & Chuva \\
\hline \multicolumn{3}{|c|}{ Comparação da sazonalidade em Floresta } \\
\hline Triplectides & 126,2 & 53,1 \\
\hline Phylloicus & 42,4 & 19,5 \\
\hline Oecetis & 33,1 & 9,4 \\
\hline Grumicha & 20,0 & 17,8 \\
\hline Helicopsyche & 12,8 & 0,6 \\
\hline Askola & 7,4 & 0,1 \\
\hline Massartella & 1,4 & 1,0 \\
\hline Smicridea & 0,9 & 0,6 \\
\hline Miroculis & 0,3 & 0,3 \\
\hline Leptonema & 1,5 & 0 \\
\hline \multicolumn{3}{|c|}{ Comparação da sazonalidade em Eucalipto } \\
\hline Triplectides & 34,2 & 58,4 \\
\hline Helicopsyche & 44,6 & 20,1 \\
\hline Phylloicus & 15,6 & 20,3 \\
\hline Oecetis & 2,6 & 18,8 \\
\hline Askola & 3,8 & 2,0 \\
\hline Polyplectropus & 3,7 & 0,3 \\
\hline Smicridea & 4,2 & 1,3 \\
\hline Polycentropus & 5,2 & 0,1 \\
\hline Grumicha & 0,3 & 1,8 \\
\hline Zelusia & 0,9 & 0,3 \\
\hline
\end{tabular}

Os resultados do teste de dispersão multivariada (PERMIDISP) mostraram que não houve diferença na diversidade beta (dados de presença e ausência e dados de abundância) entre os períodos sazonais secos e chuvosos para nascentes em áreas de floresta e nascentes em áreas de eucalipto (Figura 12). 
Figura 12 - Análises multivariadas do diagrama de dispersão mostrando a variabilidade da composição das assembleias de Ephemeroptera, Plecoptera e Trichoptera de nascentes em áreas de floresta e áreas de eucalipto nos períodos secos e chuvosos. A e B: presença/ausência; C e D: abundância.
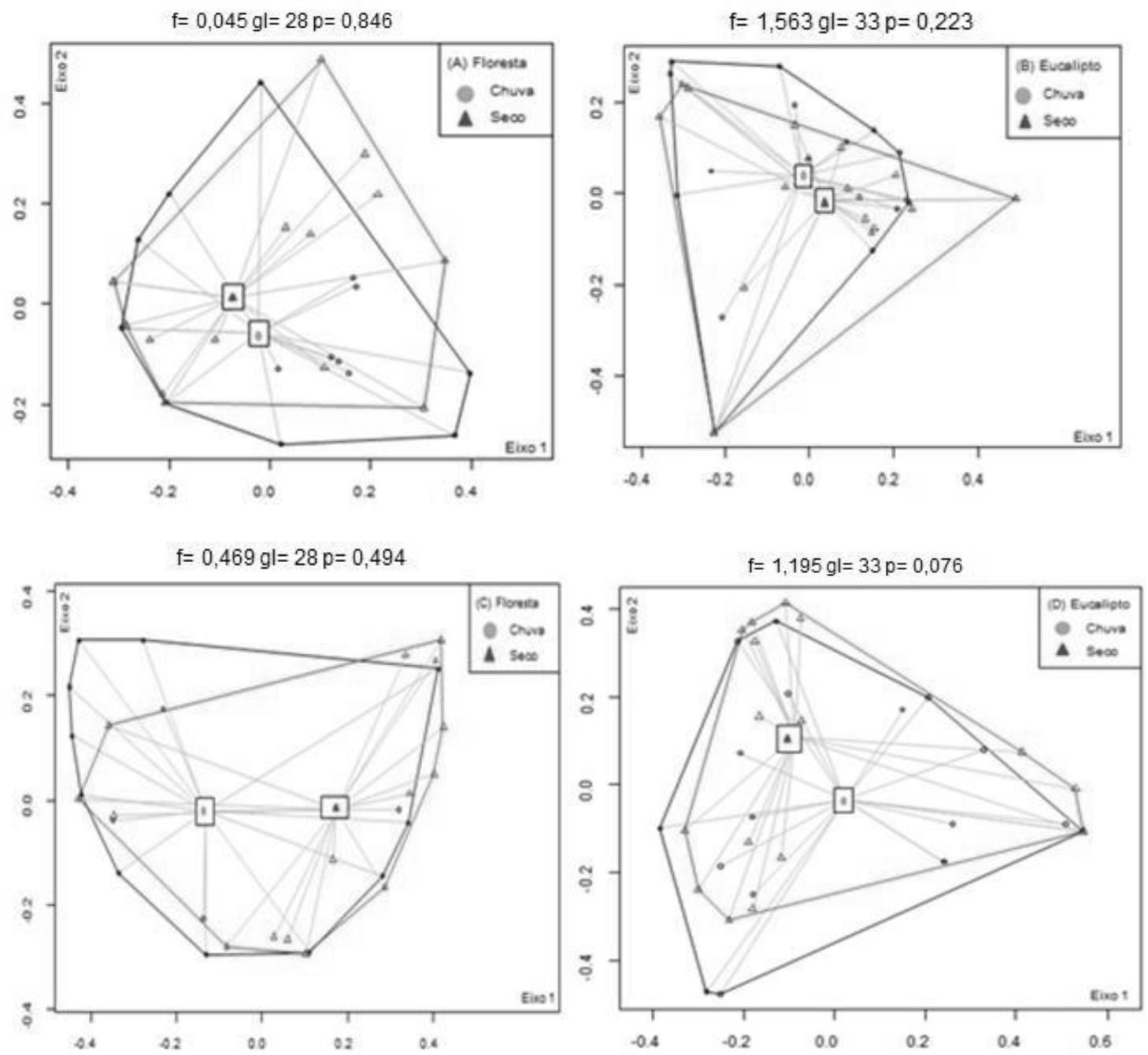

Fonte: Os autores (2021).

Os valores de diversidade beta total ( $\beta$ sor) das assembleias de EPT de nascentes em áreas de floresta e nascentes em áreas de eucalipto foram similares e altos para o período sazonal seco e chuvoso. O particionamento da diversidade beta mostrou que, nascentes em áreas de floresta e nascentes em áreas de eucalipto o componente substituição de espécies $(\beta$ sim) foi predominante em relação ao componente aninhamento (ßnes) nos períodos sazonais secos e chuvosos (Tabela 8). 
Tabela 8 - Valores de diversidade beta total ( $\beta$ sor) e seus componentes substituição ( $\beta$ sim) e aninhamento ( $\beta$ nes) para as assembleias de Ephemeroptera, Plecoptera e Trichoptera em nascentes em áreas de floresta e eucalipto nos períodos secos e chuvosos.

\begin{tabular}{lccccccc}
\hline & \multicolumn{3}{c}{ Floresta } & & \multicolumn{3}{c}{ Eucalipto } \\
\cline { 2 - 4 } \cline { 6 - 8 } & $\beta$ ssor & $\beta$ sim & $\beta$ Bnes & & $\beta$ sor & $\beta$ sim & $\beta$ nnes \\
\hline Seco & 0.840 & 0.778 & 0.061 & & 0.847 & 0.737 & 0.109 \\
Chuva & 0.851 & 0.743 & 0.108 & & 0.820 & 0.687 & 0.132 \\
\hline
\end{tabular}

Fonte: Os autores (2021).

Em relação às variáveis ambientais medidas no estudo, a análise mostrou homogeneidade dos parâmetros, sem a distinção de modificação significativa das condições ambientais das nascentes de áreas de floresta $(\mathrm{f}=0.579, \mathrm{df}=28, \mathrm{p}=0.44) \mathrm{e}$ nascentes em áreas de eucalipto $(\mathrm{f}=0.145, \mathrm{df}=40, \mathrm{p}=0.702)$ nos períodos sazonais secos e chuvosos (Figura 13).

Figura 13 - Análises multivariadas do diagrama de dispersão mostrando a variabilidade das variáveis ambientais de nascentes em áreas de floresta e áreas de eucalipto nos períodos secos e chuvosos.
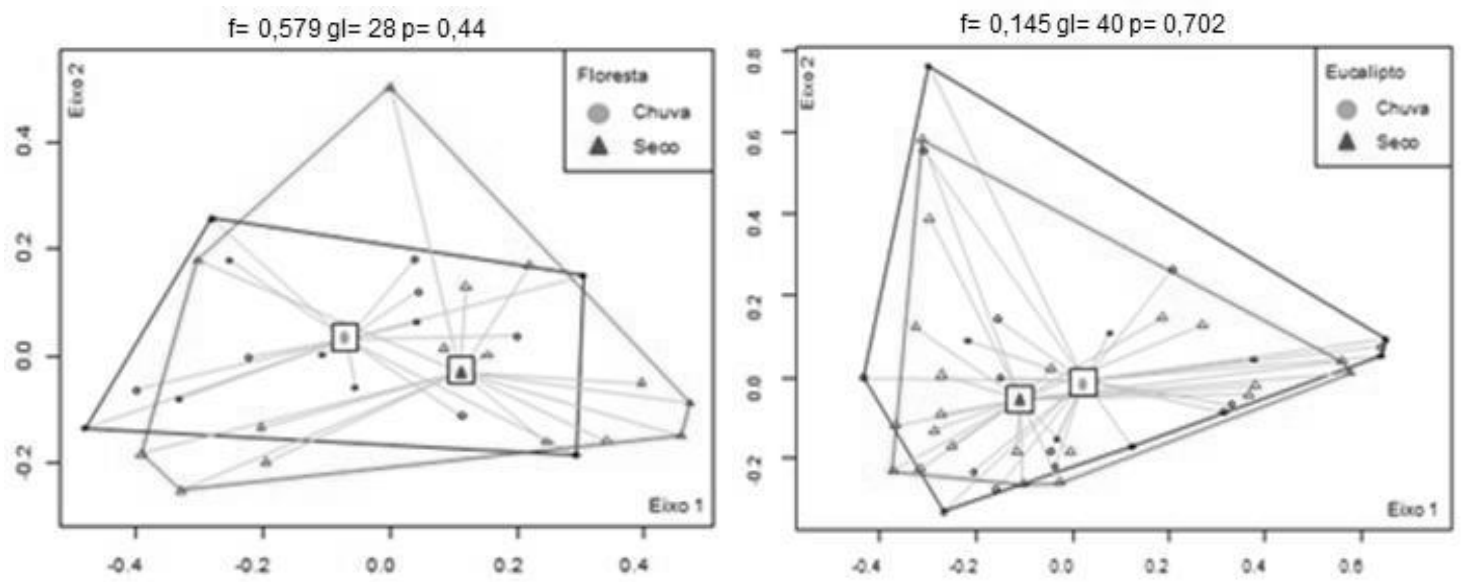

Fonte: Os autores (2021).

De acordo com os resultados do modelo linear generalizado (GLM), a variável ambiental areia fina, apresentou maior contribuição para a diversidade beta dos táxons de EPT para os períodos sazonais secos e chuvosos de nascentes em áreas de floresta. Já as variáveis ambientais condutividade e turbidez apresentaram maior contribuição para a diversidade beta para os períodos sazonais de seca e de chuva de nascentes em áreas 
de eucalipto (Tabela 9). Os valores mínimo e máximo bem como a média e desvio padrão das variáveis ambientais das nascentes em área de floresta e nascentes em área de eucalipto para os períodos sazonais de seca e de chuva podem ser visualizadas na Tabela 10.

Tabela 9 - Modelo Linear Geral (GLM) com as variáveis ambientais que mais contribuíram com a variação da diversidade beta nos períodos secos e chuvosos das nascentes em áreas de floresta e eucalipto.

\begin{tabular}{ccccc}
\hline & Estimativa & Erro Padrão & $\mathrm{t}$ valor & $\mathrm{p}$ valor \\
\hline $\begin{array}{c}\text { Floresta } \\
\text { Areia fina }\end{array}$ & 0.0807 & 0.0386 & 2.087 & 0.0468 \\
$\begin{array}{c}\text { Eucalipto } \\
\text { Condutividade }\end{array}$ & 0.0048 & 0.0011 & 4.142 & $<0.01$ \\
$\quad$ Turbidez & 0.0034 & 0.0011 & 3.023 & $<0.01$ \\
\hline Fonte: Os autores $(2021)$ & & &
\end{tabular}

Fonte: Os autores (2021). 
Tabela 10 - Variáveis ambientais das nascentes em áreas de floresta e áreas de eucalipto para os períodos secos e chuvosos (Média \pm Desvio Padrão), intervalos de mínimo e máximo (Min-Max).

\begin{tabular}{|c|c|c|c|c|c|c|c|c|c|c|c|c|}
\hline & \multicolumn{6}{|c|}{ Floresta } & \multicolumn{6}{|c|}{ Eucalipto } \\
\hline & \multicolumn{3}{|c|}{ Seco } & \multicolumn{3}{|c|}{ Chuvoso } & \multicolumn{3}{|c|}{ Seco } & \multicolumn{3}{|c|}{ Chuvoso } \\
\hline & $\min$ & $\max$ & med $\pm d e s v$ & $\min$ & $\max$ & $m e d \pm d e s v$ & $\min$ & $\max$ & med \pm desv & $\min$ & $\max$ & med $\pm d e s v$ \\
\hline Lar & 0,30 & 0,98 & $0,56 \pm 0,23$ & 0,27 & 1,30 & $0,63 \pm 0,32$ & 0,1 & 1,2 & $0,67 \pm 0,39$ & 0,11 & 1,8 & $0,82 \pm 0,41$ \\
\hline Prof & 0,10 & 0,70 & $0,38 \pm 0,20$ & 0,10 & 0,70 & $0,28 \pm 0,16$ & 0,03 & 0,9 & $0,36 \pm 0,25$ & 0,04 & 0,9 & $0,37 \pm 0,25$ \\
\hline Vaz & 0,08 & 1,01 & $0,42 \pm 0,28$ & 0,12 & 1,60 & $0,74 \pm 0,40$ & 0,08 & 2,45 & $0,51 \pm 0,60$ & 0,18 & 2,95 & $0,99 \pm 0,72$ \\
\hline Temp & 13,00 & 17,70 & $16,06 \pm 1,51$ & 20,50 & 26,60 & $22,08 \pm 1,73$ & 14,7 & 23,4 & $17,94 \pm 2,37$ & 20,60 & 24,9 & $22,67 \pm 1,40$ \\
\hline Oxi & 1,84 & 8,66 & $5,71 \pm 2,18$ & 1,47 & 6,72 & $4,28 \pm 1,65$ & 0,35 & 7,42 & $4,13 \pm 1,97$ & 0,64 & 7,57 & $4,10 \pm 2,13$ \\
\hline Cond & 5,70 & 69,80 & $22,56 \pm 19,31$ & 10,80 & 41,20 & $21,76 \pm 9,41$ & 8,4 & 110,2 & $37,84 \pm 27,11$ & 6,45 & 56,02 & $23,04 \pm 12,61$ \\
\hline $\mathrm{pH}$ & 5,05 & 6,92 & $5,97 \pm 0,71$ & 4,23 & 6,46 & $5,31 \pm 0,65$ & 4,27 & 7,03 & $6,25 \pm 0,72$ & 3,85 & 6,6 & $5,79 \pm 0,71$ \\
\hline Turb & 1,70 & 20,98 & $9,21 \pm 6,02$ & 1,50 & 31,40 & $9,86 \pm 8,62$ & 0,9 & 98,1 & $18,75 \pm 13,48$ & 0,10 & 180,2 & $23,84 \pm 41,73$ \\
\hline $\mathrm{AMG}$ & 24,88 & 83,81 & $53,50 \pm 18,94$ & 21,88 & 83,81 & $47,08 \pm 18,28$ & 15,86 & 79,26 & $39,94 \pm 19,35$ & 17,67 & 79,26 & $44,56 \pm 20,53$ \\
\hline $\mathrm{AG}$ & 8,67 & 42,09 & $25,03 \pm 10,91$ & 8,68 & 42,09 & $30,86 \pm 9,84$ & 11,74 & 50,36 & $30 \pm 8,60$ & 11,74 & 50,36 & $28,85 \pm 10,21$ \\
\hline AM & 3,46 & 38,63 & $16,11 \pm 10,82$ & 4,09 & 38,63 & $17,53 \pm 10,56$ & 3,41 & 35,28 & $21,27 \pm 9,87$ & 3,41 & 45,2 & $19,79 \pm 11,32$ \\
\hline $\mathrm{AF}$ & 0,40 & 12,93 & $5,30 \pm 3,44$ & 0,43 & 9,75 & $4,06 \pm 3,10$ & 0,59 & 12,48 & $5,86 \pm 3,44$ & 0,49 & 71,9 & $8,32 \pm 14,90$ \\
\hline $\mathrm{AMF}$ & 0,00 & 6,53 & $2,58 \pm 1,88$ & 0,00 & 4,48 & $1,53 \pm 1,15$ & 0 & 5,53 & $2,14 \pm 1,53$ & 0,00 & 5,53 & $1,72 \pm 1,40$ \\
\hline Sil/Arg & 0,00 & 2,63 & $0,80 \pm 0,74$ & 0,00 & 2,63 & $0,43 \pm 0,65$ & 0 & 1,8 & $0,62 \pm 0,50$ & 0,00 & 1,23 & $0,39 \pm 0,37$ \\
\hline $\mathrm{MO}$ & 5,04 & 64,20 & $27,75 \pm 18,69$ & 4,74 & 49,67 & $17,98 \pm 12,70$ & 0,77 & 75,9 & $21,17 \pm 22,95$ & 1,44 & 77,97 & $22,28 \pm 21,59$ \\
\hline
\end{tabular}

Fonte: Os autores (2021).

Em que: Lar= largura; Prof= profundidade; Vaz= Vazão; Temp=temperatura; Oxi= oxigênio; Cond= condutividade; Turb= turbidez; $\mathrm{AMG}=$ areia muito grossa: $\mathrm{AG}=$ areia grossa; $\mathrm{AF}=$ areia fina; $\mathrm{AMF}=$ areia muito fina; $\mathrm{Sil} / \mathrm{Arg}=$ silte e argila; $\mathrm{MO}=$ matéria orgânica. 


\subsection{DISCUSSÃO}

\subsubsection{Variação sazonal da assembleia de EPT}

Nascentes localizadas em bacias hidrográficas tropicais, como foco deste estudo, são caracterizada por marcada sazonalidade climática, com estações secas e chuvosas pronunciadas (MARMONTEL et al., 2018). Utilizando uma série temporal de três anos, o presente estudo verificou que as nascentes estudadas apresentam estabilidade e heterogeneidade de hábitats, sendo esta, caracterizada pelos diferentes tipos de material orgânico particulado de origem vegetal, em estágios diferentes de decomposição e sedimento com frações granulométricas diversas. Nascentes ambientalmente heterogêneas podem apresentar composição de espécies temporalmente estáveis, enquanto habitats homogêneos são mais sensíveis às perturbações provocadas por eventos pluviométricos (Ǩ̌OUPALOVÁ et al., 2011). Myers; Resh (2002) mencionam que a constância do fluxo de água e a estabilidade dos habitats são fatores importantes para riqueza e abundância de espécies de nascente.

Nossos resultados mostraram que a abundância de gêneros de EPT em nascente de áreas florestadas apresentou variação entre os períodos sazonais secos e chuvosos. Nestas áreas, as nascentes apresentaram maior abundância de táxons no período seco, provavelmente, reflexo de um maior acúmulo de matéria orgânica vegetal natural neste período. A formação vegetal da região estudada apresenta como característica, uma significativa perda de folhas no período seco do ano (SILVA et al., 2020) e a maior abundância de EPT nesse período em nascentes florestadas se deve principalmente aos táxons fragmentadores Triplectides, Phylloicus e Oecetis. Isso porque, os ciclos de vida de muitos organismos fragmentadores são sincronizados com a entrada de folhas no ambiente aquático durante o outono (WILLIAMS, 1991b), com pico de crescimento até o início do inverno, quando as espécies atingem alta abundância (KŘOUPALOVÁ et al., 2011).

Ainda que a folhagem do eucalipto seja persistente ao longo do ano (SCHNEIDER, 2003) e apresente alto teor de compostos secundários (por exemplo, polifenóis e taninos), que têm efeito inibitório na colonização de organismos fragmentadores (CANHOTO; GRAÇA, 1999), esta pode ter contribuído para maior abundância destes organismos em nascentes em áreas de eucalipto no período chuvoso. Uma vez que a lavagem dos compostos secundários devido à sua alta solubilidade 
(REZENDE; PETRUCIO; GONÇALVES, 2014) podem ter favorecido os fragmentadores Triplectides, Phylloicus e Oecetis. Em nascentes, a entrada de material vegetal é particularmente relevante para a composição da fauna bentônica, devido ao fato de ser uma fonte de energia importante dentro desse ecossistema (VON FUMETTI et al., 2006).

Embora seja esperado que variações sazonais de secas e de chuvas promovam mudanças na composição das espécies em ecossistemas aquáticos (BISHOP et al., 2015), nossos resultados mostraram que nascentes em áreas de floresta e áreas de eucalipto a diversidade beta não variou significativamente entre os períodos sazonais e, portanto, não confirmaram parte da nossa hipótese inicial. Isto ocorre, pois a estabilidade das nascentes reduz os efeitos da sazonalidade, tais como a amplitude e a intensidade das cheias (ABDELSALAM; TANIDA, 2013), tornando o padrão temporal de variação do regime de secas e chuvas menos intenso. De fato, áreas de eucalipto apresentam estrato arbóreo homogêneo e espaçado (CORDERO-RIVERA; ÁLVAREZ; ÁLVAREZ, 2017), mas quando conectado à vegetação ciliar, fornece a entrada de matéria orgânica para as nascentes (AMARAL; ROCHA; ALVES, 2021), criando condições que podem ter contribuído para a diversidade das assembleias de EPT durante os períodos secos e chuvosos. Assim sendo, foi possível observar neste estudo que a sazonalidade não alterou a diversidade beta de EPT de nascentes perenes em áreas de floresta e áreas de eucalipto.

Como esperado, em períodos secos e chuvosos a diversidade beta das assembleias de EPT em nascente de floresta e eucalipto se deu principalmente pelo componente turnover. A substituição de espécies e não o aninhamento parece ser um reflexo da composição variável de microhabitats (PELÁEZ; PAVANELLI, 2019) e concomitância de zonas lóticas e lênticos dentro da área das nascentes (STAUDACHER; FÜREDER, 2007). Ambientes heterogêneos oferecem várias oportunidades de nicho nos quais diferentes espécies estão adaptadas, resultando em uma maior variação na composição de espécies entre locais (HEINO; MELO; BINI, 2015). De fato, nossos resultados coadunam com aqueles obtidos em outros ecossistemas aquáticos (TONIAL et al., 2012; LI et al., 2021) ao demonstrar que a substituição dos táxons ocorre em ambientes heterogêneos, por oferecer habitats diversos para as espécies. Os altos valores de substituição das assembleias de EPT confere a importância de se conservar a vegetação ciliar das nascentes. 


\subsubsection{Variação sazonal das variáveis ambientais}

Em nosso estudo, observamos homogeneidade das variáveis ambientais entre os períodos secos e chuvosos das nascentes em áreas de floresta e eucalipto. Nascentes perenes são frequentemente consideradas ecossistemas estáveis (CANTONATI et al., 2012), com baixa variação temporal de variáveis ambientais, como temperatura e fluxo de água (CANTONATI; GERECKE; BERTUZZI, 2006). A interação entre o ambiente aquático e terrestre é um fator importante na estabilidade ambiental das nascentes (BARQUIN; SCARSBROOK, 2008). Nas áreas estudadas, o eucalipto plantado á mais de dez anos, pode ter contribuído para a redução do efeito da sazonalidade pluviométrica nas nascentes localizadas nessas áreas. Ao avaliar por oito anos o impacto da pluviosidade sobre o solo plantado com eucalipto, Martins (2010) verificou que as perdas de solo e água por erosão hídrica foram reduzidas a partir do quarto ano do cultivo. Devido a um ciclo de crescimento rápido, o eucalipto atinge a maturidade entre oito e dez anos de idade do plantio (CATERINA, 2017) e fornece melhor cobertura do solo, com a copa das árvores formando um dossel parcialmente fechado, aumentando a infiltração de água da chuva e reduzindo o carreamento do sedimento (MARTINS, 2010). Além disso, os resíduos vegetais funcionam como obstáculos ao escoamento de excedentes hídricos (FRANCO et al. 2002), reduzindo o volume e a velocidade da enxurrada para as nascentes em área de eucalipto. Assim, a estabilidade das nascentes em áreas de floresta e de eucalipto nos períodos secos e chuvosos refletiu na constância das condições ambientais analisadas.

A despeito das variáveis ambientais das nascentes estudadas, a análise GLM mostrou que a variável areia fina foi a melhor preditora para a diversidade beta entre os períodos secos e chuvosos de nascentes em área de floresta, enquanto nascentes em área de eucalipto as variáveis condutividade e turbidez foram as que mais contribuíram para diversidade beta das assembleias de EPT nos dois períodos sazonais. Nascentes em áreas de floresta são geralmente associadas a uma composição granulométrica mais grossa (AMARAL et al., 2020) e a entrada da areia fina pode ter influenciado a composição das assembleias de EPT. A entrada de sedimentos finos reduz a heterogeneidade de habitats (por exemplo, substrato grosso e interstícios associados), alterando a composição da comunidade bentônica de ecossistemas aquáticos (BURDON; MCINTOSH; HARDING, 2013). Estudos mostram também que as variáveis turbidez e condutividade são identificadas como fatores chave na estruturação 
da fauna bentônica (SKOULIKIDIS; KARAOUZAS; GRITZALIS, 2009; ROCHA, 2018). Por exemplo, Amaral et al. (2015) verificaram que o aumento de partículas em suspensão na coluna d'água dos riachos, favoreceram organismos de hábitos alimentares filtrador-coletor, como o Trichoptera do gênero Smicridea. Desta forma, apesar da diversidade beta não apresentar variação significativa entre os períodos secos e chuvosos, as variáveis encontradas podem moldar a distribuição da fauna bentônica nas nascentes em áreas de floresta e eucalipto.

\subsection{CONCLUSÃO}

Nossos resultados mostram que a baixa variabilidade sazonal da fauna reflete a estabilidade ambiental das nascentes estudadas, reduzindo o efeito na variação da diversidade beta das assembleias de EPT em nascentes em áreas de floresta e eucalipto. Verificamos também que as variáveis areia fina, condutividade e turbidez foram parâmetros ambientais determinantes na diversidade beta de EPT em nascentes de áreas de floresta e eucalipto. Além disso, os altos valores de diversidade beta registrado em nosso estudo e a predominância do componente substituição de gêneros em ambos os períodos sazonais, refletem a heterogeneidade ambiental das nascentes em áreas de floresta e eucalipto. Apesar das áreas de silvicultara apresentar estrato arbóreo espaçado e homogêneo, o eucalipto plantado há mais de dez anos, juntamente com a vegetação ciliar, pode ter reduzido o efeito dos períodos secos e chuvosos e contribuído com a entrada de matéria orgânica vegetal para as nascentes, mantendo condições favoráveis para as assembleias de EPT. Desta maneira, evidenciamos a importância da manutenção da vegetação ciliar em áreas cultivadas, uma vez que sua conservação pode contribuir para a estabilidade e heterogeneidade ambiental das nascentes diante de períodos secos e chuvosos, de forma a abrigar assembleias de EPT, importantes componentes destes ecossistemas. 


\section{REFERÊNCIAS}

ABDELSALAM, K. M.; TANIDA, K. Diversity and spatio-temporal distribution of macro-invertebrates communities in spring flows of Tsuya Stream, Gifu Prefecture, central Japan. The Egyptian Journal of Aquatic Research, v.39 n.1, p.39-50, 2013.

ALLAN, J. D. Landscapes and riverscapes: the influence of land use on stream ecosystems. Annual Review of Ecology and Systematics, v.35, p.257-284, 2004.

ABNT- Associação Brasileira de Normas Técnicas. NBR 7181: Solo - análise granulométrica. Rio de Janeiro/RJ, 1984.

ABNT- Associação Brasileira de Normas Técnicas. NBR 13600: Solo - Determinação do teor de matéria orgânica por queima a $440^{\circ} \mathrm{C}$. Rio de Janeiro/RJ, 1996.

AMARAL, P. H. M.; PEIXOTO, S. J.; MARLOM, M. M. M.; ROCHA, C. H. B.; ALVES, R. G. Caracterização granulométrica do sedimento de nascentes Tropicais em áreas plantadas com eucalipto. Ciência Florestal, v.30, n.4, p. 1075-1084, 2020.

AMARAL, P. H. M.; ROCHA, C. H. B.; ALVES, R. G. Effect of eucalyptus plantations on the taxonomic and functional structure of aquatic insect assemblages in Neotropical springs. Studies on Neotropical Fauna and Environment, p.1- 12, 2021.

ANDERSON, M. J. Distance-based tests for homogeneity of multivariate dispersions. Biometrics, v.62, p.245-253, 2006.

ANDRADE, A. L.; BRASIL, L. V.; BENONE, N. L.; SHIMANO, Y.; FARIAS, A. P. J.; MONTAGA, L. F.; DOLÉDEC, S.; JUEN, L. Influence of oil palm monoculture on the taxonomic and functional composition of aquatic insect communities in eastern Brazilian Amazonia. Ecol. Indic. v.82, p.478-483, 2017.

BARQUÍN, J.; SCARSBROOK, M. Management and conservation strategies for coldwater springs. Aquatic. Conserv. Mar. Freshw Ecosystem, v.18, n.5, p.580-591, 2008.

BASELGA, A. Partitioning the turnover and nestedness components of beta diversity. Global Ecology and Biogeography, v. 19, p.134-143, 2010.

BASELGA, A. The relationship between species replacement, dissimilarity derived from nestedness, and nestedness. Global Ecology and Biogeography, v. 21, p. 12231232, 2012.

BASELGA, A.; ORME, C. D. L. betapart: an R package for the study of beta diversity. Methods in Ecology and Evolution, v.3, p.808- 812, 2012.

BISHOP, T. R.; ROBERTSON, M. P.; VAN RENSBURG, B. J.; PARR, C. L. Contrasting species and functional beta diversity in montane ant assemblages. Journal of Biogeography, v.42, p.1776-1786, 2015. 
BISPO, P, C,; OLIVEIRA, L, G,; BINI, L, M,; SOUSA, K, G, Ephemeroptera, Plecoptera and Trichoptera from riffles in mountain streams of Central Brazil: environmental factors influencing the distribution and abundance of immatures, Brazilian Journal of Biology, São Carlos, v. 66, n. 2, p. 611-622, 2006.

BORTOLUZZI, L. N.; FERNANDEZ, O. V. Q. Medição da vazão líquida em pequenos cursos d'agua de Marechal Cândido Rondon (PR). Geografia Ensino e Pesquisa, v.12, n.1, p.4265-4275, 2008.

BOUCHARD, R. W. J. R. Guide to aquatic macroinvertebrates of the Upper Midwest. Water Resources Center, University of Minnesota, St. Paul, MN. 208p, 2004.

BRASIL. Lei 12,651/2012. 2012. Diário Oficial da União, Brasília, Distrito Federal. $1: 1$.

BROCKERHOFF, E. G.; JACTEL. H.; PARROTTA, J. A.; FERRAZ, S. F. B. Role of eucalypt and other planted forest in biodiversity conservation and the provision of biodiversity-related ecosystem services. For. Ecol. Manag. v.301, p.43-50, 2013.

BURDON, F. J.; MCINTOSH, A. R.; HARDING, J. S. 2013. Habitat loss drives threshold response of benthic invertebrate communities to deposited sediment in agricultural streams. Ecological Applications, v.23, n.5, p.1036-1047, 2013.

CALOR, A. R.; FROEHLICH, C. G. Description of the immature stages of Notalina morsei Holzenthal, 1986 (Trichoptera: Leptoceridae) and an updated key to larvae of Neotropical Leptoceridae genera. Zootaxa, v.17, p.45-54, 2008.

CANHOTO, C.; GRACA, M. A. S. Leaf Barriers to Fungal Colonization and Shredders (Tipula lateralis) Consumption of Decomposing Eucalyptus globulus. Microb. Ecol. 37:163-172, 1999.

CATERINA, G. L. Curvas de crescimento de Eucalyptus spp em plantios de diferentes espaçamentos. Ph.D., Universidade do Estado de São Paulo, Botucatu, Brasil, 82p, 2017.

CANTONATI, M.; GERECKE, R.; BERTUZZI, E. Springs of the Alps - Sensitive Ecosystems to Environmental Change: From Biodiversity Assessments to Long-term Studies. Hydrobiologia, v.562, p.59-96, 2006.

CANTONATI, M.; FÜREDER, L.; GERECKE, R.; JÜTTNER, I.; COX, E. J. Crenic habitats, hotspots for freshwater biodiversity conservation: toward an understanding of their ecology. Freshwater Science, v.21, p.463-480, 2012.

CARDOSO, P.; RIGAL, F.; CARVALHO, J. C. 2018. BAT: Biodiversity Assessment Tools. R package version 1.6.0. https ://cran.r-proje ct.org/web/packa ges/BAT.

CARLSON, P. E.; JOHNSON, R. K.; MCKIE, B. G. Optimizing stream bioassessment: habitat, season, and the impacts of land use on benthic macroinvertebrates.

Hydrobiologia, v.704, p.363-373, 2013. 
CARVALHO, J. S.; CARDOSO, P.; BORGES, P. A. V.; SCHMERA, D.; PODANI, J. Measuring fractions of beta diversity and their relationships to nestedness: a theoretical and empirical comparison of novel approaches. Oikos, v.122, p.825-834, 2013.

CORDERO-RIVERA, A.; ÁlVAREZ, M. A.; ÁLVAREZ, M. Eucalypt plantations reduce the diversity of macroinvertebrates in small forested streams. Anim. Biodivers. Conserv. v.40, n.1, v.87-97, 2017.

CRAWLET, M. J. Statistics an introduction using R. Imperial College London, 324p, 2011.

DE CASTRO, D. M. P.; DOLÉDEC, S.; CALLISTO, M. Landscape variables influence taxonomic and trait composition of insect assemblages in Neotropical savanna streams. Freshwater Biology, p.1-15, 2017.

DEATH, R. G.; WINTERBOURN, M. J. Diversity patterns in stream benthic invertebrate communities: the influence of habitat stability. Ecological Society of America, v.76, n.5, p.1-11, 1995.

FRANCO, F. S.; COUTO, L.; CARVALHO, A. F.; JUCKSCH, I.; FERNANDES FILHO, E. I.; SILVA, E.; MEIRA NETO, J. A. A. Quantificação de erosão em sistemas agrícolas agroflorestais e convencionais na Zona da Mata de Minas Gerais. Revista Árvore, v.26, p.751-760, 2002.

GRAÇA, M. A. S.; POZO, J.; CANHOTO, C.; ELÓSEGI, A. Effects of Eucalyptus globulus plantations on detritus, decomposers, and detritivores in streams. The Scientific World Journal, v.2, p.1173-1185, 2002.

HEINO J.; GRONROOS, M.; ILMONEN, J.; KARHU T.; NIVA, M.; PAASIVIRTA, L. Environmental heterogeneity and $b$ diversity of stream macroinvertebrate communities at intermediate spatial scales. Freshwater Science, v.32, p.142-154, 2013.

HEINO, J.; MELO A. S.; BINI, L. M. Reconceptualising the beta diversity environmental heterogeneity relationship in running water systems. Freshwater Biology, v.60, p.223-235, 2015.

HELMS, B. S.; SCHOONOVER, J. E.; FEMINELLA, J. W. Seasonal variability of landuse impacts on macroinvertebrate assemblages in streams of western Georgia, USA. J. N. Am. Benthol. Soc. v.28, n.4, p.991-1006, 2009.

KŘOUPALOVÁ, V.; BOJKOVÁ, J.; SCHENKOVÁ, J.; PAŘIL, P.; HORSÁK, M. Small-Scale Distribution of Aquatic Macroinvertebrates in Two Spring Fens with Different Groundwater Chemistry. Internat. Rev. Hydrobiol. v.96, n.3, p.235-256, 2011.

JACKSON, R. B.; JOBBAGY, E. G.; AVISSAR, R.; ROY, S. B.; BARRETT, D. J.; COOK, C. W.; FARLEY, K. A.; MAITRE, D. C.; MCCARL, B. A.; MURRAY, B. C. Trading water for Carbon with biological Carbon sequestration. Science, v.310, p.19441947, 2005. 
LAKE P, S. Disturbance, patchiness and diversity in streams. Journal of the North American Benthological Society, v.19, p.573-92, 2000.

LEGENDRE, P. Interpreting the replacement and richness difference components of beta diversity. Global Ecology and Biogeograph, v. 23, p.1324-1334, 2014.

LENCIONI, L.; MARZIALI, L.; ROSSARO, B. Chironomids as bioindicators of environmental quality in mountain springs. Freshwater Science, v.31, n.2, p.525-541, 2012.

LI, Z.; HEINO, J.; LIU, Z.; MENG, X.; CHEN, X.; GE, Y.; XIE, Z. The drivers of multiple dimensions of stream macroinvertebrate beta diversity across a large montane landscape. Limnol. Oceanogr. v.66, p.226-236, 2021.

MALOUFI, S.; CATHERINE, A.; MOUILLOT, D.; LOUVARD, C.; COUTE , A.; BERNARD, C.; TROUSSELLIER, M. Environmental heterogeneity among lakes promotes hyper b-diversity across phytoplankton communities. Freshwater Biology, v.61, p.633-645, 2016.

MARMONTEL, C. V. F.; LUCAS-BORJA, M. E.; RODRIGUES, V. A.; ZEMA, V. A. Effects of land use and sampling distance on water quality in tropical headwater springs (Pimenta creek, São Paulo State, Brazil). Science of The Total Environment, v.622, p.680-690-701, 2018.

MARTINS, S. G. SILVA, M. L. N.; AVANZI, J. C.; CURI, N.; FONSECA, S. Fator cobertura e manejo do solo e perdas de solo e água em cultivo de eucalipto e em Mata Atlântica nos Tabuleiros Costeiros do estado do Espírito Santo. Scientia Forestalis, v.38, n.87, p.517-526, 2010.

MCGEOCH, M. A.; VAN RENSBURG, B. J.; BOTES, A. Blackwell Science, Ltd The verification and application of bioindicators: a case study of dung beetles in a savanna ecosystem. Journal of Applied Ecology, v.39, p.661-672, 2002.

MORAES, B. C; COSTA, J. M. N.; COSTA, A. C. L.; COSTA, M. H. Variação espacial e temporal da precipitação no estado do Pará. Acta Amazonica, v.35, n.2, p.207-214, 2005.

MOSCHINI-CARLOS, V.; POMPÊO, M. L. M.; HENRY, R. 1999. Dinâmica da comunidade perifítica na zona de desembocadura do rio Paranapanema, represa do Jurumirim, SP. In: Henry, R. (Ed.). Ecologia de reservatórios: Estrutura, função e aspectos sociais. FUNDIBIO/FAESP, p. 690-734, Botucatu, Brasil.

MYERS, N.; RESH, V. H.Trichoptera and other macroinvertebrates in springs of the Great Basin: species composition, richness, and distribution. Western North American Naturalist, v.62, n.1, p.1-13, 2002.

O'GORMAN, E. J.; EMMERSON, M. C. Perturbations to trophic interactions and the stability of complex food webs. PNAS, v.106, n.32, p.13393-13398, 2009. 
OLIFIERS, M. H.; DORVILLÉ, L. F. M.; NESSIMIAN, J. L.; HAMADA, N. A key to Brazilian genera of Plecoptera (insecta) based on nynphs. Zootaxa, v.65, p.1-15, 2004.

OKSANEN, J.; BLANCHET, F. G.; KINDT, R.; LEGENDRE, P.; MINCHIN, P. R.; O'HARA, R. B.; WAGNER, H. 2016. Vegan: Community Ecology Package. R package Version 3.0-2.

OLIVEIRA, L. G.; BISPO, P. C.; SÁ, N. C. Ecologia de comunidades de insetos bentônicos (Ephemeroptera, Plecoptera e Trichoptera), em córregos do parque ecológico de Goiânia, Goiás, Brasil. Revista brasileira de Zoologia, v.14, n.4, p. 867876, 1997.

OLIVEIRA JUNIOR, J. C.; DIAS, H. C. T. Precipitação efetiva em fragmento secundário da Mata Atlântica. Rev. Árvore, v.29, n.1, p. 1-12, 2005.

PASSY, S. I.; BLANCHET, F. G. Algal communities in human-impacted stream ecosystems suffer beta-diversity decline. Diversity and Distributions, v.13, p.670-679, 2007.

PEEL, M. C.; FINLAYSON, B. L.; MCMAHON, T. A. Updated world map of the Köppen Geiger climate classification. Hydrol. Earth Syst. Sci. Discuss. v.4, p.439-473, 2007.

PELÁEZ, O.; PAVANELLI, C. S. Environmental heterogeneity and dispersal limitation explain different aspects of $\beta$-diversity in Neotropical fish assemblages. Freshwater Biology. v.64, p.497-505, 2019.

PES, A. M. O. Taxonomia, estrutura e riqueza das assembleias de larvas e pupas de Trichoptera (Insecta), em igarapés na Amazônia central. Ph.D., Instituto Nacional de Pesquisas da Amazônia, Universidade Federal de Manaus, Manaus, Brasil, 165p, 2005.

PES, A. M. O.; HAMADA, N.; NESSIMIAN, J. L. Chaves de identificacão de larvas para famílias e gêneros de Trichoptera (Insecta) da Amazônia Central, Brasil. Rev. Bras. Entomol. v.49, p.181-204, 2005.

PJF - PREFEITURA DE JUIZ DE FORA, MINAS GERAIS. 1996. Plano Diretor de Juiz de Fora. Juiz de Fora: Concorde. $<$ https://leismunicipais.com.br/plano-diretorjuiz-de-fora-mg>.

PJF - PREFEITURA DE JUIZ DE FORA, MINAS GERAIS. 2001. Anuário estatístico de Juiz de Fora 2001: base de dados 2000. Centro de Pesquisas Sociais, Juiz de Fora, p 80 .

R CORE TEAM. 2016. R: A Language and Environment for Statistical Computing. R Foundation of Statistical Computing, Vienna.

RASBAND, W. S. 2012. ImageJ. U. S. National Institutes of Health, Bethesda, MD. 
REISS, M.; CHIFFLARD, P. Different forest cover and its impact on eco-hydrological traits, invertebrate fauna and biodiversity of spring habitats. Nature Conservation, v.27, p.85-99, 2018.

ROCHA, M. P.; BINI, L. M.; DOMISCH, S.; TOLONEN, K. T.; JYRKÄNKALLIOMIKKOLA, J.; SOININEN, J.; HJORT, J.; HEINO, J. Local environment and space drive multiple facets of stream macroinvertebrate beta diversity. Journal of Biogeography,v.45, p.2744-2754, 2018.

REZENDE, R. S.; PETRUCIO, M. M.; GONÇALVES, J. F., JR. The effects of spatial scale on breakdown of leaves in a tropical watershed. PloS one, 9, n. 5, p. e97072e97072, 2014.

RODRIGUES, V.; ESTRANY, J. RANZINI, M.; CICCO, V.; MARTÍN-BENITO, J. M. T.; HEDO, J.; LUCAS-BORJAM M. E.; Effects of land use and seasonality os stream water quality in a small tropical catchment: the headwater of Córrego Água Limpa, São Paulo (Brazil). Science of the Total Environment, v.622, p.1553-1561, 2018.

SADA, D. W.; FLEISHMAN, E.; MURPHY, D. D. Associations among springdependent aquatic assemblages and environmental and land use gradients in a Mojave Desert mountain range. Diversity and Distributions, v.11, p.91-99, 2005.

SALLES, F. F. A ordem Ephemeroptera no Brasil (insecta): taxonomia e diversidade. Ph.D. Thesis, Universidade Federal de Viçosa, Viçosa, Brasil. 108p, 2006.

SCHNEIDER, M. F. Consequências da Acumulação de folhas secas napPlantação de Eucalipto em Zitundo, Distrito de Matutuíne. Boletim de Investigação Florestal, [sn], p.37-42, 2003.

SILVA, N. T. C. Macroinvertebrados bentônicos em áreas com diferentes graus de preservação ambiental na bacia do ribeirão Mestre d'Armas, DF. Dissertação, Universidade de Brasília, Brasília, Brasil, 2007.

SILVA, N. C.; SALIMENA, F. R. G.; CARVALHO, F. A.; RIBEIRO, J. H. C.; FONSECA, C. R.; MOREIRA, B.; VALENTE, A. S. M.; PIFANO, S. Flora fanerogâmica do Jardim Botânico da Universidade Federal de Juiz de Fora, Minas Gerais, Brasil. Rodriguésia, v.71, 2020.

SKOULIKIDIS, N. T.; KARAOUZAS, L.; GRITZALIS, K. C. Identifying key environmental variables structuring benthic fauna for establishing a biotic typology for Greek running waters. Limnologica, v.39, n.1, p.56-66, 2009.

SMITH, H.; WOOD, P.J. Flow permanence and macroinvertebrate community variability in limestone spring systems. Hydrobiologia, v.487, p.45-58, 2002.

SOUZA, F. N.; MARIANO, R.; MOREIRA, T.; CAMPIOLO, S. Influence of the landscape in different scales on the EPT community (Ephemeroptera, Plecoptera and Trichoptera) in an Atlantic Forest region. Environmental Monitoring and Assessment, v.192, n.391, 2020. 
STAUDACHER, K.; FÜREDER, L. Habitat Complexity and Invertebrates in Selected Alpine Springs (Schütt, Carinthia, Austria). Internat. Rev. Hydrobiol. v.92, v.4, p.465-479, 2007.

SUGANUMA, M. S.; TOREZAN, J. M. D.; CAVALHEIRO, A. L.; VANZELA, A. L. L.; BENATO, T. Comparando metodologias para avaliar a cobertura do dossel e a luminosidade no sub-bosque de um reflorestamento e uma floresta madura. Revista Árvore, v.32, p.377-385, 2008.

SUHAILA, A. H.; SALMAH, M.R. C.; AL-SHAMI, S.A. Temporal distribution of Ephemeroptera, Plecoptera and Trichoptera (EPT) adults at a tropical forest stream: response to seasonal variations. The Environmentalist, v.32, p.28-34, 2012.

TONIAL, M. S. L.; SILVA, H. L. R.; TONIAL, I. J.; COSTA, M. C.; JUNIOR, N. J.S.; DINIZ-FILHO, J. A. F Geographical patterns and partition of turnover and richness components of beta-diversity in faunas from Tocantins river valley. Brasilian Journal of Biology, v.72, n.3, p.497-504, 2012.

VAN EVERDINGEN, R. O. Physical, chemical, and distributional aspects of Canadian springs. The Memoirs of the Entomological Society of Canada, v.123, p.7-28, 1991.

VAN DER KAMP, G. The hydrogeology of springs in relation to the biodiversity of spring fauna: a review. Journal of the Kansas Entomological Society, v. 68, n. 2, p. 417, 1995.

WILLIAMS, D. D. The spring as an interface between groundwater and lotic faunas and as a tool in assessing groundwater quality. Verh.Internat. Verein. Limnol. v.24, n. 3, p.1621-1624, 1991a.

WILLIAMS, D. D. Life history traits of aquatic arthropods in springs. Mem. Entomol. Soc. Can. v.155, p.107-124, 1991b.

VAN DER KAMP, G. The hydrogeology of springs in relation to the biodiversity of spring fauna: a review. Journal of the Kansas Entomological Society, v.68, p.4-17, 1995.

VON FUMETTI, S.; Nagel, P.; Scheifhacken, N.; Baltes, B. Factors governing macrozoobenthic assemblages in perennial springs in north-western Switzerland. Hydrobiologia, v.568, p.467-475, 2006.

VON FUMETTI, S.; BLATTNER, L. Faunistic assemblages of natural springs in different areas in the Swiss National Park a small-scale comparison. Hydrobiologia, v. 793, n. 1, p. 175-184, 2017.

YOKOYAMA, E.; PACIENCIA, G. P.; BISPO, P. C.; OLIVEIRA, L. G.; BISPO, P. C. A sazonalidade ambiental afeta a composição faunística de Ephemeroptera e Trichoptera em um riacho de Cerrado do Sudeste do Brasil? Ambiência Guarapuava, v.8, n.1, p.73-84, 2012. 
ZHANG, M.; CHEN, F.; SHI, X.; YANG, Z.; KONG, F. Association between temporal and spatial beta diversity in phytoplankton. Ecography, 41: 1345-1356, 2018

ZARDO, D. C.; HARDOIM, E. L.; AMORIM, R.; MALHEIROS, C. H. Variação espaço-temporal naabundância de ordens e famílias de macroinvertebrados bentônicos registrados em área de nascente, Campo Verde-MT. Revista Uniara, v.16, n. 